San Jose State University

SJSU ScholarWorks

Master's Theses

Master's Theses and Graduate Research

1995

\title{
Distribution, abundance, habitat use, and respiration patterns of harbor porpoise (Phocoena phocoena) off the northern San Juan Islands, Washington
}

Kimberly L. Raum-Suryan

San Jose State University

Follow this and additional works at: https://scholarworks.sjsu.edu/etd_theses

\section{Recommended Citation}

Raum-Suryan, Kimberly L., "Distribution, abundance, habitat use, and respiration patterns of harbor porpoise (Phocoena phocoena) off the northern San Juan Islands, Washington" (1995). Master's Theses. 1026.

DOI: https://doi.org/10.31979/etd.ktpq-c4bf

https://scholarworks.sjsu.edu/etd_theses/1026

This Thesis is brought to you for free and open access by the Master's Theses and Graduate Research at SJSU ScholarWorks. It has been accepted for inclusion in Master's Theses by an authorized administrator of SJSU ScholarWorks. For more information, please contact scholarworks@sjsu.edu. 


\section{INFORMATION TO USERS}

This manuscript has been reproduced from the mictofilm master. UMI films the text directly from the original or copy submitted. Thus, some thesis and dissertation copies are in typewriter face, while others may be from any type of computer printer.

The quality of this reproduction is dependent upon the quality of the copy submitted. Broken or indistinct print, colored or poor quality illustrations and photographs, print bleedthrough, substandard margins, and improper alignment can adversely affect reproduction.

In the unlikely event that the author did not send UMI a complete manuscript and there are missing pages, these will be noted. Also, if unauthorized copyright material had to be removed, a note will indicate the deletion.

Oversize materials (e.g., maps, drawings, charts) are reproduced by sectioning the original, beginning at the upper left-hand corner and continuing from left to right in equal sections with small overlaps. Each original is also photographed in one exposure and is included in recuced form at the back of the book.

Photographs included in the original manuscript have been reproduced xerographically in this copy. Higher quality $6^{\prime \prime} \times 9^{n}$ black and white photographic prints are available for any photographs or illustrations appearing in this copy for an additional charge. Contact UMI directly to order.

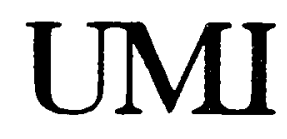

A Bell \& Howell information Company 300 North Zeeb Road. Ann Arbor. MI 48106-1346 USA 
$\ldots$ 
DISTRIBUTION, ABUNDANCE, HABITAT USE, AND RESPIRATION

PATTERNS OF HARBOR PORPOISE (Phocoena phocoena) OFF

THE NORTHERN SAN JUAN ISLANDS, WASHINGTON.

\author{
A Thesis \\ Presented to \\ The Faculty of Moss Landing Marine Laboratories \\ San Jose State University \\ In Partial Fulfillment \\ of the requirements for the Degree \\ Master of Science
}

by

Kimberly L. Raum-Suryan

May, 1995 
OMI Number: 1374617

UMI Microform 1374617

Copyright 1995, by UMI Company. All rights reserved.

This microform edition is protected against unauthorized copying under Title 17, United States Code.

\section{UMI}

300 North Zeeb Road

Ann Arbor, MT 48103 
(C) 1995

Kimberly L. Raum-Suryan

ALL RIGHTS RESERVED 
APPROVED FOR THE DEPARTMENT OF MOSS LANDING MARINE LABORATORIES

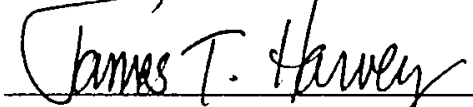

Dr. James T. Harvey, As $\$$ stand Professor, Committee Chair iss Sale

Dr. Jay Barlow, Head of Coastal Marine Mammal Program Southwest Fisheries Science Center, NMFS

Willard Buphor

Dr. William W. Broenkow, Professor

APPROVED FOR THE UNIVERSITY

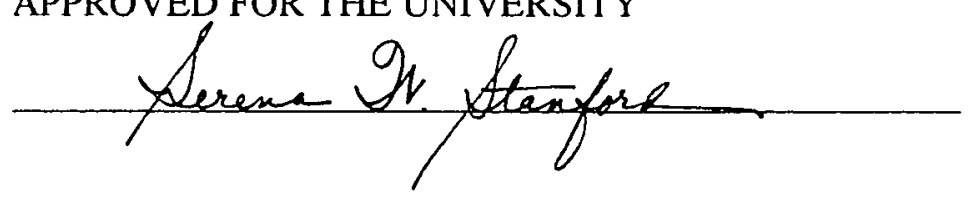




\title{
ABSTRACT \\ DISTRIBUTION, ABUNDANCE, HABITAT USE, AND RESPIRATION \\ PATTERNS OF HARBOR PORPOISE (Phocoena phocoena) OFF THE NORTHERN SAN JUAN ISLANDS, WASHINGTON.
}

\author{
by Kimberly L. Raum-Suryan
}

Boat and shore-based surveys were conducted from June to August 1991 and June to October 1992 to determine harbor porpoise distribution, density, abundance, and habitat use off the northern San Juan Islands, Washington. An estimated 299 harbor porpoise (1.26 harbor porpoise $/ \mathrm{km}^{2}$ ) occurred patchily within $237 \mathrm{~km}^{2}$. Harbor porpoise occurred in water of $10.1^{\circ}$ to $16.3^{\circ} \mathrm{C}$, were generally observed more than expected in depths $>125 \mathrm{~m}$ and over shallow slopes $(<10 \%)$, and less than expected in depths $<75 \mathrm{~m}$. Abundance of harbor porpoise in relation to deep waters, flood tides, and tide rips off Point Doughty, Orcas Island, may indicate the importance of these waters as foraging areas. Mean duration of dives for individuals and groups $(n=95)$ was $6.6 \mathrm{sec}$ $(\mathrm{SE}=0.11, \mathrm{n}=1,551)$ for dives $<30 \mathrm{sec}$ and $125 \sec (\mathrm{SE}=5.32, \mathrm{n}=156)$ for dives $>30 \mathrm{sec}$ duration. 


\section{ACKNOWLEDGMENTS}

This study was made possible due to the help of many people. I would like to thank Birgit Kriete for her enthusiasm and encouragement during the initial stages of this project. I also greatly appreciate the help of Dr. Robert DeLong, Steve Osmek, and Steve Jeffries in obtaining funding for the project in 1991 and 1992. I sincerely thank the members of my committee, Dr. Jay Barlow and Dr. William Broenkow for helpful discussions and valuable comments regarding my thesis. I am very grateful to my advisor, Dr. James Harvey, for his guidance, support, and assistance throughout this study. Even with twenty-six graduate students, he always found time for each of us.

I am indebted to the "Patos Island Pack-Mules" who assisted me during the 1992 field season, their patience and perseverance helped make this research possible. I especially thank Tomo Eguchi for his endless support during all aspects of this study. I also thank Karen Russel for her assistance, enthusiasm, and humor. Doug Huddle did a terrific job keeping us "on track" during our vessel surveys. I thank John and Marilyn Raum for all of their help during their "vacation" on Patos Island. John (U-haul) Raum was especially helpful with scat sifting and relocation from the island to the mainland.

Funding and support for this project was made possible by The National Marine Mammal Laboratories (especially Dr. Robert DeLong, Steve Osmek, Harriet Huber, Dave Rugh, and Dr. Marilyn Dahlheim), The Washington Department of Wildlife (especially Steve Jeffries), Dr. Earl H. And Ethel M. Myers/Oceanographic and Marine Biology 
Trust, Lerner-Gray Fund for Marine Research, Packard Foundation, The Whale Museum, and Save The Whales, Inc. I also thank John Calambokidis for all of his help and encouragement throughout this study.

I thank the students and faculty at Moss Landing Marine Laboratories for all of the fun times as well as providing a great educational experience. I especially thank Sheila Baldridge for her assistance in obtaining library materials and for being such a great friend.

I would like to thank my parents, John and Marilyn Raum and my brother, Brad Raum, for their love and support. I am extremely grateful to my parents for instilling in me the drive to reach for my goals, no matter what they are or where they take me. I also thank Joe and Bea Suryan for their constant encouragement and support, they are the best "parents in law" anyone could ever have.

I am forever grateful to my husband and best friend, Rob Suryan, for his constant love, support, encouragement, and humor throughout my graduate and field work. To Rob I say "The best is yet to come". Lastly, I thank Kisha and Shasta just for being themselves. 


\section{TABLE OF CONTENTS}

\section{Page}

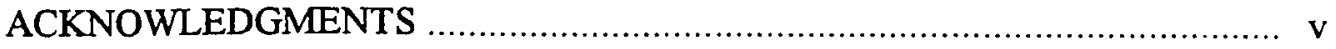

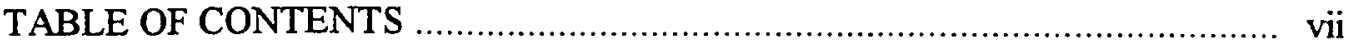

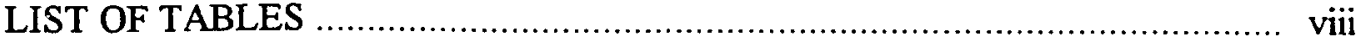

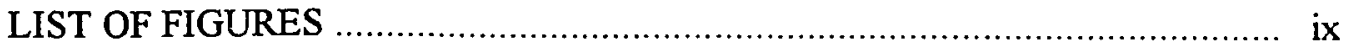

CHAPTER 1: Distribution, Abundance, and Habitat Use

INTRODUCTION …................................................................. I

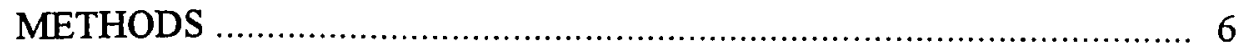

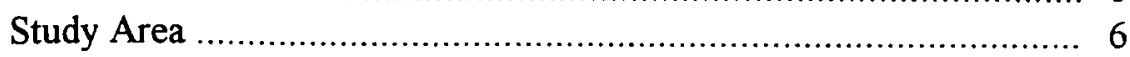

Random Boat Surveys ........................................................... 6

Fixed Boat Surveys ........................................................... 11

Shore-Based Location Surveys ................................................. 12

Shore-Based Abundance Surveys ............................................. 14

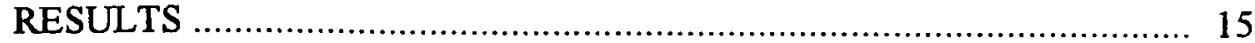

Random Boat Surveys ....................................................... 15

Fixed Boat Surveys ............................................................. 18

Shore-Based Location Surveys ........................................ 18

Shore-Based Abundance Surveys ........................................ 20

DISCUSSION ................................................................... 22

CHAPTER 2: Respiration Patterns

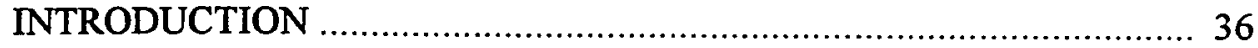

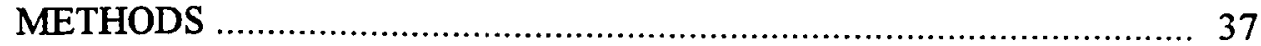

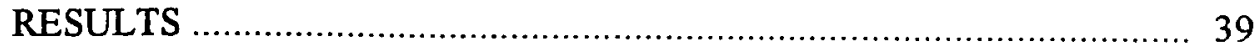

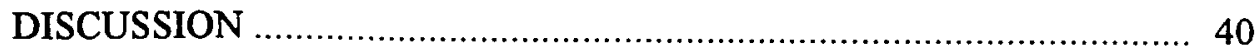

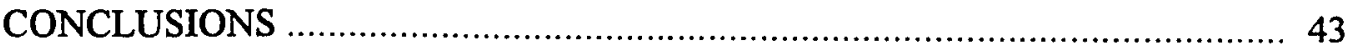

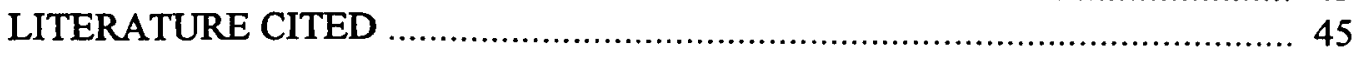

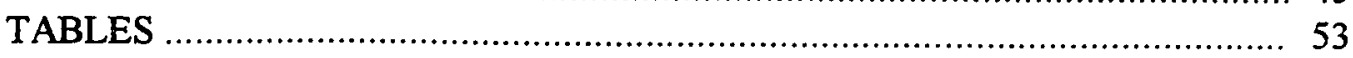

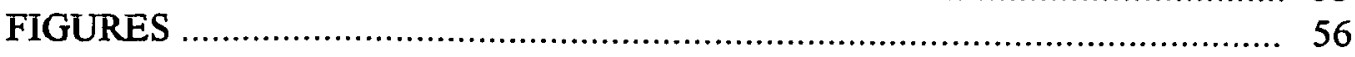

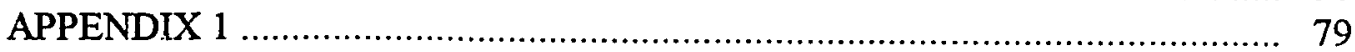




\section{LIST OF TABLES}

Page

Table 1. Harbor porpoise abundance estimates for each section (A - E) and all sections combined surveyed within the northern San Juan Islands, Washington from June to October 1992.

Table 2. Mean, standard error (SE), number of sightings, and number of harbor porpoise determined during fixed boat surveys in 1991 and 1992. In 1992, the number of harbor porpoise observed (Obs.) are presented, as are values from four randomly chosen surveys used in analysis (Anal; comparing mean number of harbor porpoise sighted along each transect in 1991 and 1992). $\mathrm{N}$ refers to the number of transect "sides" (bow out to $90^{\circ}$ on port or starboard) surveyed.

Table 3. Mean duration of dives (seconds) and breath series (a series of short duration, $<30 \mathrm{sec}$, dives, preceded and followed by a greater duration, $>30 \mathrm{sec}$, dive) of harbor porpoise individuals, and individuals and groups combined. Standard error (SE) and number of dives or breath series intervals $(N)$ also are presented. 


\section{LIST OF FIGURES}

Page

Figure 1. Study area stratified into five approximately equal sections (lettered A, B, C, D, E) used during random boat surveys from June to October 1992. Point Doughty, Orcas Island, Washington was the site of shore-based surveys in 1991 and 1992.

Figure 2. Random boat transects $(n=73)$ completed from June to October 1992 within five stratified sections (A, B, C, D, E), northern San Juan Islands, Washington.

Figure 3. Six fixed transects (numbered 1, 2, 3, 5, 6, 7) conducted from July to August 1991 and 1992, northern San Juan Islands, Washington.

Figure 4. Shore-based study area (Point Doughty, Orcas Island, Washington), stratified into eight sections, used for location and abundance surveys in 1992. Area was stratified to allocate equal effort to entire study area during each survey. Flattop Island (indicated by arrow) was used as an additional observation platform in 1991.

Figure 5. Location of harbor porpoise sighted $(n=301)$ during random boat surveys $(n=73)$ completed from June to October 1992 within five stratified sections (A, B, C, D, E), northern San Juan Islands, Washington. Arrows between locations indicate movement of harbor porpoise from one location to another.

Figure 6. Probability detection distribution for perpendicular sighting distances of harbor porpoise. Bars represent frequency of sightings and line represents the half-normal/hermite model of best fit. 
Figure 7. Mean number of harbor porpoise (a) and mean water depth (b) of each section (A - E) determined during random boat surveys (June to October 1992). Vertical lines represent standard error and " $n$ " represents number of transects completed in each section (a) and random depth locations plotted within each section $(b ;$ total $=584)$.

Figure 8. Depth distribution of harbor porpoise sightings $(n=275)$ determined from random boat surveys (June to October 1994) in relation to expected distribution of harbor porpoise if they were distributed randomly with depth (as determined from depths at 584 random locations). An asterisk $\left({ }^{*}\right)$ designates a significant $(p<0.05)$ difference determined using chi-square goodness of fit analyses.

Figure 9. Mean percentage slope of seafloor for each section (A - E) determined from random boat surveys. Vertical lines represent standard error and " $n$ " represents the number of random slope locations plotted within each section (total $=584$ ).

Figure 10. Harbor porpoise sightings $(n=275)$ from random boat surveys (June to October 1992) in relation to expected distribution if porpoise were distributed randomly with slope (as determined from slopes at 584 random locations). An asterisk $\left({ }^{*}\right)$ designates a significant $(p<0.05)$ difference, determined using chi-square goodness of fit analyses.

Figure 11. Sea surface temperatures $\left({ }^{\circ} \mathrm{C}\right)$ recorded at harbor porpoise sightings $(n=267)$ in relation to expected distribution of harbor porpoise if they were distributed randomly with temperature (as determined from temperatures at 427 locations along 73 random transect lines). An asterisk (*) designates a significant $(p<0.05)$ difference, determined using chi-square goodness of fit analyses.

Figure 12. Mean number of harbor porpoise observed per minute during random boat surveys (June to October 1992) for all sections (A - E) combined. Vertical lines represent standard error. 
Figure 13. Harbor porpoise locations along fixed boat transects $(1,2,3,5,6,7)$ in 1991 and 1992 off the northern San Juan Islands, Washington. The " $x$ " denotes locations of harbor porpoise sighted in 1991 and the "•" locations in 1992. Arrows between locations indicate movement of harbor porpoise from one location to another.

Figure 14. Location of harbor porpoise sighted $(n=617)$ during shorebased location surveys (Point Doughty Orcas Island, Washington) from June to October 1992. Due to errors in some distance calculations, 17 sightings were not plotted.

Figure 15. Number of harbor porpoise observed per section $(1-8)$ from Point Doughty, Orcas Island, Washington. Only surveys when all eight sections were completed $(n=63)$ are included (some surveys or sections of surveys were terminated due to adverse weather conditions).

Figure 16. Number of harbor porpoise sightings $(n=634)$ in relation to distance from Point Doughty, Orcas Island, Washington.

Figure 17. Frequency of harbor porpoise sightings $(n=634)$ in relation to expected distribution if porpoise were distributed randomiy with depth (a) and slope (b; as determined from depths and slopes at 160 random locations) off Point Doughty, Orcas Island, Washington. An asterisk $\left({ }^{*}\right)$ designates a significant $(p<0.05)$ difference, determined using chi-square goodness of fit analyses.

Figure 18. Percent frequency occurrence of harbor porpoise when tide rips were present and absent (a) and when milling and traveling behavior was observed (b) during shore-based location surveys off Point Doughty, Orcas Island, Washington in 1991 and 1992.

Figure 19. Density of harbor porpoise for four months of 1992 off Point Doughty, Orcas Island, Washington. Vertical lines represent standard error and " $n$ " represents the number of surveys in each month. 
Figure 20. Group size of harbor porpoise in relation to month (determined during abundance surveys off Point Doughty, Orcas Island, Washington). "N" represents total number of harbor porpoise sightings within each month.

Figure 21. Mean number of harbor porpoise observed per minute before and after low tide (a) and high tide (b) off Point Doughty, Orcas Island, Washington. The numbers above each bar represent sample size during each time block and vertical lines represent standard error.

Figure 22. Mean number of harbor porpoise observed per minute in relation to the frequency of the maximum flood current recorded on twenty days (June to September 1992) during 69 abundance surveys off Point Doughty, Orcas Island, Washington.

Figure 23. Duration of dives (seconds) between breaths for individual harbor porpoise observed from shore or boat off the northem San Juan Islands, Washington. 


\section{CHAPTER 1: Distribution, Abundance, and Habitat Use}

\section{INTRODUCTION}

Harbor porpoise (Phocoena phocoena), averaging 1.5 to $1.6 \mathrm{~m}$ length and 45 to $60 \mathrm{~kg}$ weight (Gaskin et al. 1974), are one of the smallest oceanic cetaceans. In the temperate and subarctic waters of the northern hemisphere (Gaskin 1984), four populations (North Pacific, Eastern and Western Atlantic, and Black Sea-Sea of-Azov) of harbor porpoise are morphologically and meristically distinguishable (Yurick 1977, Yurick and Gaskin 1987). Although predominantly observed in coastal waters (Prescott and Fiorelli 1980, Gaskin 1984), harbor porpoise also inhabit offshore shallow waters (Georges and Grand Banks; Gaskin 1984), sometimes occurring 37 km offshore (Scheffer and Slipp 1948, Pike and MacAskie 1969). Off California, Oregon, and Washington, the majority (96\%) of harbor porpoise occur over continental shelf waters (Green et al. 1992); however, harbor porpoise have been sighted $37 \mathrm{~km}$ (Barlow 1988) and $70 \mathrm{~km}$ offshore (Green et al. 1992).

Harbor porpoise abundance varies seasonally and by region off California, Oregon, and Washington (Dohl et al. 1983, Barlow 1988, Barlow et al. 1988, Green et al. 1992). Near Cape Bianco, California, harbor porpoise were observed most frequently in fall, winter, and spring. From Hoh Head, Washington to Columbia River, Oregon, and from Newport to Cape Blanco, Oregon; however, harbor porpoise sightings were most frequent in fall (Green et al. 1992). From Cape Flattery, Washington to Point Conception, California, Barlow (1988) estimated approximately 46,000 (SE $\pm 7,800$ ) harbor porpoise, with greatest densities occurring off the northern Oregon coast. The current population of harbor porpoise off California is estimated at 13,370 (C.V. $=0.18$; Barlow and Forney 
1994). Green et al. (1992) estimated about 15,000 harbor porpoise in waters 0 to $100 \mathrm{~m}$ deep off Oregon and Washington. Calambokidis et al. (1992, 1993b) estimated nearly 30,000 harbor porpoise off Oregon and Washington, with 960 harbor porpoise occurring off the San Juan Islands, Washington.

The presence of harbor porpoise in nearshore waters makes them particularly vulnerable to impacts from human activities, such as boat traffic, environmental pollution, drift net and coastal gillnet fisheries. Amudin and Amudin (1974) reported harbor porpoise avoided motor boats that came within 100 to $200 \mathrm{~m}$ of the porpoise. Gaskin (1977), Prescott and Fiorelli (1980), and Flaherty and Stark (1982) also have reported boat avoidance by harbor porpoise. Along the west coast of the United States harbor porpoise have high pollutant loads, certain pollutant ratios (DDE/PCB) being greater off Washington than off Oregon or California (Calambokidis and Barlow 1991). Substantial numbers of harbor porpoise also are caught and killed incidentally in United States and Canadian fisheries, including halibut setnet fisheries off California, and salmon driftnet and gillnet fisheries off Alaska, British Columbia, and Washington (Marine Mammal Commission 1990, 1993; Barlow et al. 1994). The continued incidental take of harbor porpoise in salmon gillnets by commercial fishermen may be the most serious factor affecting growth of the harbor porpoise population in Puget Sound (Everitt et al. 1980).

Harbor porpoise are present year-round off the coast and inland waters of Washington State. Historically, harbor porpoise occurred throughout the Strait of Juan de Fuca, Washington Sound (San Juan Island archipelago), and south into Puget Sound. Once considered the most commonly observed cetacean in southern Puget Sound (Scheffer and Slipp 1948), harbor porpoise sightings are now rare (Everitt et al. 1980, Calambokidis et al. 1984, Calambokidis et al. 1985). Although harbor porpoise have not been sighted off the central San Juan Islands in recent years (Flaherty and Stark 1982, 
Calambokidis et al. 1993b), sightings off the northern San Juan Islands are common (Flaherty and Stark 1982, Calambokidis et al. 1985, Calambokidis et al. 1993b). Reasons for the disappearance of harbor porpoise from South Puget Sound are unclear, but may be due to reduced prey availability, disturbance, or pollution.

Many biological (e.g. prey) and physical oceanographic factors (e.g. depth, seafloor relief, tidal currents, surface temperature) affect the distribution of cetaceans. In the Southern California Bight, the sighting frequency of Delphinus sp. increased as seafloor relief increased (Hui 1979). Greater upwelling and mixing of nutrients in areas of high relief possibly increased the densities of anchovy (Engraulis mordax), thereby influencing distribution of Delphinus (Hui 1979). Feeding areas of resident killer whales (Orcinus orca) in northern Puget Sound were characterized as regions of high relief bathymetry and shallow reefs, both having increased prey availability (Heimlich-Boran 1987). Most sightings of Dall's porpoise (Phocoenoides dalli) in Puget Sound occurred in areas of high relief bathymetry and during flood tides (Miller 1989). In the Gulf of California, bottlenose dolphins (Tursiops truncatus) were abundant near the mouths of estuaries, in areas characterized by shallow, sandy bottoms and turbid water, where dolphins were presumably feeding (Ballance 1987).

Harbor porpoise distribution in relation to depth, bathymetric features, and tidal State has been extensively studied in the Bay of Fundy, Canada (Gaskin 1977, Smith and Gaskin 1983, Watson and Gaskin 1983, Read and Gaskin 1985, Watts and Gaskin 1985). Increased prey availability in deep waters may be a factor governing the distribution of harbor porpoise. Smith and Gaskin (1983) found a significant positive correlation between abundance of mother-calf pairs and bottom depth and copepod (Calanus spp.) density. Abundance of harbor porpoise also was correlated positively with depth and physiographic features that concentrated Atlantic herring (Clupea harengus) in near- 
surface waters (Watts and Gaskin 1985). Tidal state affected movements of harbor porpoise in the Bay of Fundy; harbor porpoise were observed more often during flood tide than ebb tide (Watson 1976) and moved inshore during flood tides and offshore during ebb tides (Gaskin and Watson 1985).

Depth distribution of harbor porpoise off the United States differs between waters off the coast and among island regions. Off the Pacific coast of California, Oregon, and Washington, harbor porpoise were most often associated with shallow waters $(<120 \mathrm{~m})$ along the continental slope (Barlow 1988). In contrast, Flaherty and Stark (1982) recorded the occurrence of harbor porpoise over depths up to $310 \mathrm{~m}$ off the San Juan Islands, Washington.

Other factors that may influence distribution of harbor porpoise include tidal fluctuations, tide rips, and sea surface temperature. Harbor porpoise were observed most often in areas of high relief bathymetry, and in or near tide rips off the San Juan Islands, Washington (Flaherty and Stark 1982). Harbor porpoise were most frequently observed at high tide in Sitakaday Narrows, southeast Alaska (Taylor and Dawson 1984) and during flood tide in Monterey Bay, California (Sekiguchi 1987). Dorfman (1990) reported harbor porpoise were positively correlated with surface temperature within Monterey Bay.

Sighting frequencies of harbor porpoise often vary throughout the day. Off southeast Alaska, Dahiheim et al. (1991) reported harbor porpoise appeared abundant mid-morning, less abundant midday, and abundant again in mid to late afternoon. Flaherty and Stark (1982) sighted the greatest number of harbor porpoise during midday off the San Juan Islands, Washington. Within Monterey Bay, California, more harbor porpoise were observed nearshore in the morning and fewer in the afternoon (Sekiguchi 1987). In Sitakaday Narrows and Adams Inlet, southeast Alaska, however, there was no correlation between abundance of harbor porpoise and time of day (Taylor and Dawson 1984). 
Seasonal and daily movements of harbor porpoise may be influenced by movements of their prey (Gaskin 1977). Harbor porpoise eat mainly small, nonspiny schooling fishes (Everitt et al. 1980, Evans 1987). Distribution and abundance of Atlantic herring, the most important prey of harbor porpoise in the Bay of Fundy (Smith and Gaskin 1974, Recchia and Read 1989), were primary factors affecting the distribution of harbor porpoise in the Bay of Fundy (Gaskin et al. 1985). In Monterey Bay, California, harbor porpoise fed mainly on market squid (Loligo opalescens), northern anchovy, juvenile rockfish (Sebastes sp.), Pacific hake (Merluccius productus), and Pacific tomcod (Microgadus proximus; Jones 1981, Sekiguchi 1987, Dorfman 1990). Within Washington state waters, harbor porpoise fed on Pacific herring (Clupea pallasi), market squid, smelt (Osmeridae; Gearin and Johnson 1991), and shad (Alosa sapidissima; Scheffer and Slipp 1948).

Because of the disappearance of harbor porpoise from southern Puget Sound as well as the central San Juan Islands in recent years, it is important to determine the abundance of harbor porpoise in the northern San Juan Isiands as well as habitat variables that may influence their distribution. The main objectives of this study were to determine: 1) spatial and temporal distribution, density, and abundance of harbor porpoise occurring off the northern San Juan Islands; 2) the relationship of harbor porpoise to depth and percentage slope of the seafioor, sea surface temperature, tides, tide rips, and time of day; 3) behavior of harbor porpoise in relation to boats; and 4) the influence of environmental variables on harbor porpoise distribution off Point Doughty, Orcas Island, Washington. 


\section{METHODS}

\section{Study Area}

Washington Sound is located in the northwest corner of Washington State $\left(48^{\circ} 15^{\prime}\right.$ to $48^{\circ} 50^{\prime} \mathrm{N}$ and $122^{\circ} 27^{\prime}$ to $123^{\circ} 13^{\prime} \mathrm{W}$ ), between the southern portion of Vancouver Island and the mainland, from Fidalgo Island to north of Vancouver, including the American and Canadian islands of the San Juan Archipelago (Kozloff 1973). Mean diurnal tide heights are between 1.3 and 2.9 meters (NOAA 1991). Northern Washington Sound (northern San Juan Islands) has numerous islands and reefs with deep channels and strong currents and tide rips. Boat transects and shore-based observations were conducted off the northwestern San Juan Islands, including waters surrounding Waldron Island, north and west of San Juan Island, and north of Orcas Island (Fig. 1).

\section{Random Boat Surveys}

Randomly located boat transects ( $n=73$; Fig. 2) were conducted from 27 June to 2 October 1992 within a study area composed of five strata (lettered A - E; Fig. 2) to determine harbor porpoise distribution, density, abundance, and habitat use. Eight-km transects were randomly chosen within each approximately equal (42 to $\left.50 \mathrm{~km}^{2}\right)$ stratum (stratification provided maximum area coverage using a random numbers table to determine starting point and compass bearing). Placement of transects were constrained by the boundaries of, and islands or reefs within, strata (some regions of each strata were not adequately sampled because islands prevented an 8-km transect from being placed within stratum boundaries). When possible, the five strata, hereafter referred to as sections, were surveyed on the same day. 
Transects were surveyed using a $7.3 \mathrm{~m}$ Aluminum Marine Patrol vessel during Beaufort sea state 0 (wind speed $=0-1.8 \mathrm{~km} / \mathrm{hr}$ ), $\mathrm{l}$ ( wind speed $=1.8-5.6 \mathrm{~km} / \mathrm{hr}$ ), or rarely Beaufort 2 (wind speed $=7.4-11 \mathrm{~km} / \mathrm{hr}$ ). Each transect was completed in approximately $52 \mathrm{~min}$, at an average boat speed of $9 \mathrm{~km} / \mathrm{hr}$. Based on an average sighting distance of $324 \mathrm{~m}$ to a harbor porpoise (from 1991 surveys) and recorded mean dive durations of 1.5 to $2.3 \mathrm{~min}$ (Taylor and Dawson 1984) and 0.4 to $1.4 \mathrm{~min}$ (Watson and Gaskin 1983), I assumed that at $9 \mathrm{~km} / \mathrm{hr}$ all harbor porpoise were sighted along the trackline of each transect (i.e. vessel traveled $300 \mathrm{~m}$ in $2.0 \mathrm{~min}$ allowing harbor porpoise to surface before passage of vessel).

Date, time, and tidal phase (flood or $\mathrm{sbb}$ ) were recorded before each transect. At the beginning and end of each transect, secchi disk readings were recorded to the nearest $0.1 \mathrm{~m}$ and sea surface temperatures were recorded to the nearest $0.1^{\circ} \mathrm{C}$. During surveys, two observers divided the field of view across the forward $180^{\circ}$ of the transect path. Observations were made from the roof of the vessel (height above the waterline $=2.68 \mathrm{~m}$, measured to the observers' eyes while in surveying position) with the unaided eye and Fujinon $7 \times 50$ reticle and compass binoculars. When a harbor porpoise was located, an observer recorded: time, group size and composition, compass bearing to the porpoise, reticle marks on oculars, Beaufort sea state and visibility (unacceptable to excellent, Appendix 1), number of boats, birds, and marine mammals within $1 \mathrm{~km}$ of vessel, direction of harbor porpoise travel, and presence or absence of tide rips. A group of harbor porpoise was defined as two or more porpoise visible at the water's surface within three body lengths $(5 \mathrm{~m})$ of each other, having nearly synchronous diving patterns $(<15$ seconds between sighting of each individual). Loran coordinates, Beaufort sea state, visibility, sea surface temperature, and number of boats within $1 \mathrm{~km}$ of the vessel were recorded every ten minutes during surveys and for each harbor porpoise sighting. Depth and seafloor 
slope (at each harbor porpoise sighting) were determined from National Oceanic and Atmospheric Administration (NOAA) navigational charts after harbor porpoise locations were plotted.

Locations of harbor porpoise were determined with the aid of Fujinon $7 \times 50$ reticle (each reticle $=17 \mathrm{~min}$ or $0.283^{\circ}$ ) and compass binoculars. Vertical angle was calculated as the angle between the horizon and the harbor porpoise. Distance to harbor porpoise was calculated as:

$$
\mathrm{D}_{\mathrm{r}}=\frac{\mathrm{H}}{\tan (a)}
$$

where $D_{r}=$ the radial distance from the vessel to the porpoise, $H=$ the eyeheight of observers, and $\alpha=$ the vertical angle between the horizon and porpoise. Locations were plotted on NOAA navigational charts using Loran (Latitude/Longitude) coordinates of the vessel at time of harbor porpoise sighting, and distance and bearing to sighting.

Seafloor depth and slope were determined using a NOAA navigational chart and bathymetric map. Percentage slope was calculated as:

$$
\% \text { slope }=\frac{\mathrm{dz}}{\mathrm{ds}} * 100 \% \text {, }
$$

where $\mathrm{dz}=$ the difference between the two closest depths $(\mathrm{m})$ printed on the chart on either side of a random point or harbor porpoise location, and $\mathrm{ds}=$ the distance $(\mathrm{m})$ between those two depths.

To determine if harbor porpoise occurred over depths and slopes in proportion to available depths and slopes in the study area, eight random points were plotted within a $2 \mathrm{~km}$ strip along the length of each $8-\mathrm{km}$ transect $(n=73$ transects, 584 points). Adequate sample size of depth and slope was determined by plotting precision 
(standard deviation/mean) against sample size. Seafloor depth and slope available in the study area in relation to areas of harbor porpoise occurrence were compared using chisquare goodness of fit analyses.

Perpendicular distance from the trackline to harbor porpoise was determined using:

$$
\mathrm{D}_{\mathrm{p}}=\mathrm{D}_{\mathrm{r}} * \sin (\alpha) \text {, }
$$

where $D_{p}=$ perpendicular distance, $D_{r}=$ the radial distance to the harbor porpoise, and $\alpha=$ the angle off the trackline (the difference between the trackline heading and the bearing to porpoise).

Density and abundance estimates were calculated using line transect methodology as described by Burnham et al. (1980) and the computer program DISTANCE (Laake et al. 1993). Density estimates of harbor porpoise sightings $(n=250)$ were calculated for each section $(A-E)$, and all sections combined $(n=70)$. Transects with Beaufort sea state of $2(n=3)$ were deleted from analyses because sighting rates of harbor porpoise in Beaufort 2 are less than Beaufort 0 or 1 (Barlow 1988). Density was calculated as:

$$
D=\frac{n * f(0) * s}{2 L}
$$

where $n=$ number of individual harbor porpoise sightings, $f(0)=$ the probability density function of distances from the trackline, evaluated at zero distance, $s=$ average group size of harbor porpoise sightings, and $\mathrm{L}=$ total length of the trackline. Abundance was calculated as density multiplied by area of each section (A - E) and all sections $\left(237 \mathrm{~km}^{2}\right)$. Relatively large sample sizes are required to estimate $f(0)$ accurately; therefore, values of $\mathrm{f}(0)$ were estimated for each section by pooling all sightings in all sections. Effective strip width is defined as $1 / \mathrm{f}(0)$, which equals one-half the transect width such that as many 
objects are detected outside the strip as remain undetected within it (Buckland et al. 1993). Variance was estimated for all sections combined using bootstrap analyses $(n=200)$ as in Buckland et al. (1993). Because group size was independent of distance from the trackline (determined through size-bias regression analysis using DISTANCE), average group size was used to calculate density.

Uniform, half-normal/hermite, hazard rate, and negative exponential models were compared to the frequency distributions of perpendicular sighting distance of harbor porpoise to trackline using DISTANCE. Several groupings and truncation points were investigated to achieve the best model fit. Buckland et al. (1993) recommend truncating 5 to $10 \%$ of objects detected at the greatest distances from the trackline. The halfnormal/hermite model, grouped into $50 \mathrm{~m}$ intervals and truncated at $750 \mathrm{~m}$ (deleting $5 \%$ of sightings), was chosen based on the lowest Aikaike Information Criterion (AIC; Buckland et al. 1993) score for all sections combined. Aikaike Information Criterion identifies a model that fits the data well with the least number of parameters. The probability detection function, $g(0)$, was assumed to be one (all harbor porpoise on the trackline were assumed to be seen) based on the speed of the vessel $(9 \mathrm{~km} / \mathrm{hr})$ during excellent sighting conditions (Beaufort $\leq 1$ ).

To test whether the frequency of occurrence of harbor porpoise was independent of frequency of tidal currents and surface temperature, I used chi-square goodness of fit analyses. More surveys were conducted during flood tide $(n=52)$ than ebb tide $(n=17)$, therefore, number of harbor porpoise observed per minute during flood or ebb tide was used to standardize the data. A Mann Whitney U nonparametric two-sample test was conducted to examine differences in number of harbor porpoise observed per minute for each transect $(n=73)$ during flood and ebb tides. 
Not all times of day were sampled equally; therefore, abundance of harbor porpoise in relation to time of day was compared using number of porpoise observed per minute to standardize the data. Mean number of harbor porpoise observed per minute for each hour of daylight was compared using Kruskal-Wallis nonparametric analysis of variance and Kolmogorov-Smirnov goodness of fit analyses. Nonparametric statistics were used for data with non-normal distributions or unequal variances.

\section{Fixed Boat Surveys}

Six 8-km transect lines (hereafter called fixed transects; Fig. 3), placed in areas of harbor porpoise occurrence (information from Orca Hotline, The Whale Museum, Friday Harbor, Washington and preliminary harbor porpoise surveys), were regularly surveyed from 27 July to 26 August 1991 and 24 July to 28 August 1992 to determine temporal changes in harbor porpoise distribution between 1991 and 1992. Logistical problems in obtaining a suitable vessel in 1991 postponed fixed transect surveys until late July. Also in 1991, there was only one observer per survey; therefore, only one half the transect (bow out to $90^{\circ}$ port or starboard) was surveyed. In 1992, two observers surveyed both sides of the trackline (bow out to $90^{\circ}$ port and starboard). Because random boat surveys were the main focus of the 1992 field season, fixed transect surveys were completed only from July to August 1992, corresponding to the same time period of sampling as 1991 .

Harbor porpoise were counted from a $7.3 \mathrm{~m}$ vessel during a Beaufort sea state of 0 or 1 . Each fixed transect survey was conducted at an average speed of $11 \mathrm{~km} / \mathrm{hr}$, and completed in 40 to 45 minutes. This vessel speed was chosen in 1991, and to be consistent, 1992 fixed transect surveys were conducted at the same speed (instead of $9 \mathrm{~km} / \mathrm{hr}$ as in random boat surveys). Order of transect coverage was randomly selected when possible. Because of variable sighting conditions among transects each day, 
however, transects with favorable conditions were sampled to maximize data collection. Harbor porpoise locations were calculated as in random boat survey methods.

Comparisons of mean number of sightings of harbor porpoise per survey between 1991 and 1992 were calculated using a t-test. Because both sides of the vessel were observed during a single survey in 1992, each side could not be considered an independent sample. Therefore, one side of the vessel was randomly chosen from each survey in 1992 to compare with 1991.

\section{Shore-based Location Surveys}

Location surveys were conducted to determine the spatial distribution and habitat use of harbor porpoise within an area of relatively high harbor porpoise concentrations (determined from preliminary surveys in 1991 from Point Doughty, Orcas Island, Washington). Locations of harbor porpoise were recorded within a $240^{\circ}$ viewing area every $1.9 \mathrm{~h}$ between $0800 \mathrm{~h}$ and $1900 \mathrm{~h}$ from Point Doughty (Fig. 4). Each section of the study area, stratified into eight approximately equal sections to allow equal viewing effort (Fig. 4), was scanned for six minutes per survey (total $=48 \mathrm{~min}$ ). A survey was considered complete if all eight sections were observed (wind and sun glare terminated some surveys). Observer height above the water was $17.1 \mathrm{~m}$ at mean lower low water (MLLW). Observations were made using the unaided eye, 7 x 50 Fujinon reticle and compass binoculars, and a Nikon NT-2A (17 x hand ground lens) theodolite. A theodolite was used to determine locations of harbor porpoise relative to the observer by using the observer's eye height above the water at each sighting and vertical angle to harbor porpoise (see explanation in random boat transect methods). Height of the theodolite above the water was measured directly or estimated using a cosine prediction of tide height from predicted high and low tides (San Juan Current and Tide Tables, published by 
Island Canoe, Bainbridge Island, Washington). The observation point at Point Doughty was near a vertical rock ledge, which allowed the observer to directly measure theodolite heights (using a tape measure with a float attached) above water level. Direct measurement of height above water was accurate to approximately $0.1 \mathrm{~m}$.

Shore-based surveys were conducted during a Beaufort sea state of 0 or 1 , and occasionally during Beaufort 2. Each time a harbor porpoise was sighted, the following were recorded: date, time, group size and composition, location, tidal state, presence of tide rips, boats, birds, other marine mammals, behavior (traveling, milling, pop-splash, other), sea state, and visibility. Traveling was defined as an individual or group of harbor porpoise proceeding in a single direction, having nearly synchronous dive patterns.

Milling was defined as an individual or group visible at the water's surface in different orientations, remaining within a confined area for greater than three durations at surface. Pop-splashing was defined as a quick duration at surface with a vigorous vertical motion causing a vertical splash (Scheffer and Slipp 1948, Taylor and Dawson 1984).

Once distances were calculated from Point Doughty to harbor porpoise sightings, locations were plotted on NOAA navigational charts. Depth and seafloor slope were determined using a NOAA navigational chart and bathymetric map. Slope was calculated as in random boat methods section. Random points $(n=160)$ were plotted within each of the eight sections to determine if harbor porpoise occurred over depths and slopes in proportion to those available. Adequacy of sample size was determined by plotting precision (standard deviation/mean) against sample size.

To test whether the frequency of occurrence of harbor porpoise was independent of frequency of tidal currents, tide rips, depth, slope, and behavior, I used chi-square goodness of fit analyses. 


\section{Shore-based Abundance Surveys}

Shore-based observations were conducted from Point Doughty, Orcas Island, Washington (Fig. 4). Surveys of harbor porpoise abundance were conducted every $1.6 \mathrm{~h}$ (alternately with shore-based location surveys) from approximately $0800 \mathrm{~h}$ to $1800 \mathrm{~h}$ during Beaufort sea state of 0 or 1 . Survey methods were modeled after Taylor and Dawson (1984). Beginning at the center of the survey area, two observers recorded: time, tidal state, number of harbor porpoise per group, number of boats, and behavior of harbor porpoise. Each binocular field of view (approximately $6^{\circ}$ viewing angle) was surveyed for two minutes. Two minutes was chosen because most harbor porpoise would have one but not two breath series (Taylor and Dawson 1984). A breath series was defined as a series of short duration dives ( $<30 \mathrm{~s}$ ), which were preceded and followed by a greater duration dive ( $>30 \mathrm{~s}$ ). Survey area was calculated using the furthest distance harbor porpoise could be consistently seen with $7 \times 50$ reticle and compass binoculars $(3.0 \mathrm{~km})$ within the $212^{\circ}$ viewing area (total area $=16.68 \mathrm{~km}^{2}$ ). Duration of each survey was approximately 36 to 40 minutes from center of survey area to opposite boundaries.

Water current speed was calculated at a current station located near Point Doughty, Orcas Island (San Juan Current Guide). Time of maximum flood and maximum ebb tide was determined for each survey day and compared with time of maximum frequency of occurrence of harbor porpoise.

Harbor porpoise density was calculated for each survey. Density and number of harbor porpoise observed per minute in relation to tide state were analyzed using a Kruskal-Wallis nonparametric analysis of variance. Mean number of harbor porpoise observed per minute for each hour of daylight surveyed was analyzed using Kruskal-Wallis nonparametric analysis of variance and Kolmogorov-Smirnov goodness of fit analysis. A Tukey-type multiple comparison test (Zar 1984) was used to compare densities among 
months using mean ranks (Miller 1966) when Kruskal-Wallis analysis was significant. Numbers of harbor porpoise occurring during flood versus ebb tide were compared using a t-test after log transformation. Pearson correlation was used to compare numbers of harbor porpoise with numbers of boats present.

\section{RESULTS}

\section{Random Boat Surveys}

There were 301 sightings of 526 harbor porpoise observed (Fig. 5) during random boat surveys, of which 20 sightings ( 39 porpoise) were possible resightings, therefore not used for analysis. An average of 4.4 harbor porpoise sightings were recorded per hour (8.1 harbor porpoise per hour), with group sizes of 1 to 8 (mean $=1.87, \mathrm{SE}=0.06$, $\mathrm{n}=278$ ) individuals. Thirteen cow/calf pairs were observed between June and September. Harbor porpoise were sighted on $75 \%$ of surveys and at a mean perpendicular distance from the trackline of $237 \mathrm{~m}(\mathrm{SE}=13.89, \mathrm{n}=246$, range: 0 to $1060 \mathrm{~m})$. The halfnormal/hermite model, truncated at $750 \mathrm{~m}$, best fit the frequency distribution of perpendicular distance of harbor porpoise sighted from the trackline (Fig. 6). Using harbor porpoise sightings $(n=250)$ for all sections combined, the effective half-strip width $(E S W)$ was an estimated $337 \mathrm{~m}(95 \%$ C.I. $=307-371 \mathrm{~m} ; \mathrm{CV}=0.048)$, with an $\mathrm{f}(0)$ of $2.96 / \mathrm{km}(\mathrm{SE}=0.14$, C.I. $=2.70-3.25, \mathrm{CV}=0.048)$.

No significant correlation $\left(r^{2}=0.097, n=250, p=0.938\right)$ was detected between harbor porpoise group size and perpendicular distance from the trackline. For surveys conducted during Beaufort $\leq 1(n=70)$ in all sections $(A-E)$, the mean group size was 1.91 harbor porpoise $(\mathrm{SE}=0.07, \mathrm{n}=250$; Table 1$)$ and mean density was 1.26 harbor

porpoise $/ \mathrm{km}^{2}\left(\mathrm{SE}=0.20\right.$, C.I. $=0.9-1.7$ porpoise $/ \mathrm{km}^{2}$; Table 1$)$. Harbor porpoise 
densities were least in section A $\left(0.60\right.$ porpoise $/ \mathrm{km}^{2}, \mathrm{SE}=0.21$, C.I. $\left.=0.3-1.2\right)$, and greatest in section $\mathrm{D}\left(2.3\right.$ porpoise $/ \mathrm{km}^{2}, \mathrm{SE}=0.74$, C.I. $=1.2-4.4 ;$ Table 1$)$. There were an estimated 299 harbor porpoise (C.I. $=219-409$ ) in all sections (Table 1), ranging from 30 harbor porpoise $($ C.I. $=15-60)$ in section A to 121 harbor porpoise (C.I. $=62-221$ ) in section $\mathrm{D}$ (Table 1).

Mean number of harbor porpoise per survey was greatest in section $\mathrm{D}$ and least in section E (Fig. 7a). Mean depth throughout the study area was $108.12 \mathrm{~m}(\mathrm{SE}=21.68$, $n=584$ ), section $D$ had the greatest mean depth and section $E$ the least (Fig. 7b). Harbor porpoise were distributed over a depth range of 20.1 to $235.0 \mathrm{~m}$ (mean $=141.6 \mathrm{~m}$, $\mathrm{SE}=2.43, \mathrm{n}=275$ ), with $83 \%$ of harbor porpoise sightings occurring over depths greater than $100 \mathrm{~m}$. Significantly $(\mathrm{p}<0.05)$ fewer than expected harbor porpoise occurred in depths less than $75 \mathrm{~m}$ and significantly $(\mathrm{p}<0.05)$ more than expected in four depth categories greater than $100 \mathrm{~m}(125$ - 150, 150 - 175, 200 - 225, 225 - $250 \mathrm{~m}$; Fig. 8).

Mean seafloor slope for all sections combined was $9.85 \%(\mathrm{SE}=0.656, \mathrm{n}=584)$. Section B had the least slope and section C the greatest (Fig. 9). Harbor porpoise were sighted over a mean slope of $6.90 \%(\mathrm{SE}=0.51, \mathrm{n}=275$, range: $0.37 \%$ to $45.75 \%)$. The greatest number of harbor porpoise sightings $(79 \%)$ occurred over shallow slopes $(<10 \%)$. There were significantly $(p<0.05)$ greater numbers of harbor porpoise sightings than expected in category 0 to $2 \%$ slope, and significantly $(p<0.05)$ fewer numbers of harbor porpoise than expected in categories 6 to $8 \%, 18$ to $20 \%$, and $>26 \%$ slope (Fig. 10).

Mean surface temperature recorded during all transects was $12.6^{\circ} \mathrm{C}(\mathrm{SE}=0.081$, $\mathrm{n}=427$, range: $10.1^{\circ}$ to $17.5^{\circ} \mathrm{C}$ ). Little variability was found among the five sections, Section $\mathrm{E}$ had the greatest mean surface temperature (mean $=13.46^{\circ} \mathrm{C}, \mathrm{SE}=0.215$, 
$\mathrm{n}=69)$ and section $\mathrm{B}$ the least (mean $=12.34^{\circ} \mathrm{C}, \mathrm{SE}=0.136, \mathrm{n}=97$ ). Mean surface temperature recorded during harbor porpoise sightings was $12.1^{\circ} \mathrm{C}(\mathrm{SE}=0.09, \mathrm{n}=267$, range: $10.1^{\circ}$ to $16.3^{\circ} \mathrm{C}$ ). Harbor porpoise were sighted more frequently than expected $(p<0.05)$ in water temperatures of $11^{\circ}$ to $12^{\circ} \mathrm{C}$ (Fig. 11). Mean secchi reading for all harbor porpoise sightings was $9.3 \mathrm{~m}(\mathrm{SE}=0.09, \mathrm{n}=275$, range: 5.7 to $11.9 \mathrm{~m})$.

No significant difference was detected between number of harbor porpoise observed per minute during flood and ebb tides $(U=315.5, n=69, p=0.076)$. There were significantly more harbor porpoise sightings in the absence than in the presence of tide rips $\left(\chi^{2}=10.96, n=275, p<0.05\right)$. Because equal numbers of surveys were not conducted when tide rips were present or absent, however, these results may be biased.

Greatest number of harbor porpoise were observed in mid-morning (1000 h) and afternoon $(1400$ to $1500 \mathrm{~h})$ throughout the study area. Fewer harbor porpoise were observed at midday (1100 to 1300 h; Fig. 12), although there was no significant difference $(H=10.99, n=274, p=0.276)$ among mean number of harbor porpoise observed per minute and each hour of daylight surveyed (0900 to $1800 \mathrm{~h}$ ).

During one random transect conducted within section C on 22 September 1992, several gulls (Larus sp.), Common Murres (Uria aalge), harbor seals (Phoca vitulina), one minke whale (Balaenoptera acutorostrata), and at least 18 harbor porpoise were apparently feeding on a large school of Pacific herring (species was determined using a dip net and the position of herring was determined using a paper read-out fathometer). Harbor porpoise occurred directly over the herring school and were high porpoising, swimming rapidly, making sharp turns, pop-splashing, and milling within the area of the herring. This was the only occurrence when there was direct evidence of harbor porpoise feeding on a particular prey item. There were no other instances when harbor porpoise sightings were related to large congregations $(>100)$ of birds. 


\section{Fixed Boat Surveys}

Fifty-six sightings of 92 harbor porpoise were recorded during 33 surveys (port or starboard) in 1991, and 69 sightings of 118 harbor porpoise during 24 surveys (both sides of vessel surveyed) in 1992 (Fig. 13). Harbor porpoise were sighted during 79\% of surveys in 1991 and $75 \%$ in 1992 . Three surveys were terminated due to poor sighting conditions in 1991. Mean group size was 1.6 harbor porpoise $(\mathrm{SE}=0.09, \mathrm{n}=56)$ in 1991 and 1.71 harbor porpoise $(\mathrm{SE}=0.127, \mathrm{n}=69)$ in 1992. Distribution of harbor porpoise was patchy but similar between 1991 and 1992 (Fig. 13).

The greatest number of harbor porpoise sightings recorded per survey were along transects 1, 2, and 5 in 1991 and transects 1 and 5 in 1992 (Table 2; Fig. 13). The least number of sightings were recorded for transects 3 and 6 in 1991 and 1992 (Table 2;

Fig. 13). Mean number of harbor porpoise sightings per survey was not significantly different $(p>0.05)$ between 1991 and 1992 for any of the fixed transects. Sample sizes for all transects were low because of the limited survey period (July to August).

Minke whales and Dall's porpoise were the only other cetaceans observed near harbor porpoise during both random and fixed boat surveys. Killer whales were observed during random boat surveys, but at distances greater than $2 \mathrm{~km}$ from the trackline.

\section{Shore-based Location Surveys}

Harbor porpoise were observed from Point Doughty, Orcas Island, Washington (Fig. 4) on eight days in 1991 and 21 days in 1992. Each of the eight sections (Fig. 4) of the shore-based study area (viewing area $=240^{\circ}$ ) were surveyed at least 63 times on 21 days from June to October 1992. Of the 634 harbor porpoise sightings 
(1176 porpoise) recorded in 1992, 617 were plotted (Fig. 14). Seventeen harbor porpoise sightings were not plotted due to errors in theodolite data collection. Most harbor porpoise sightings ( $74 \%$ ) occurred in section 3 (123 individuals), section 4 (169 individuals), and section 5 (128 individuals), with fewest sightings occurring in section 1 (13 individuals) and section 8 (20 individuals; Fig. 15). Harbor porpoise sightings ( $\mathrm{n}=53$ ) observed during incomplete surveys (due to poor sighting conditions) were not included. Mean distance from Point Doughty to harbor porpoise was $1472 \mathrm{~m}$ $(\mathrm{SE}=26.9, \mathrm{n}=605$, range: 174 to $3815 \mathrm{~m}$; Fig. 16). Mean harbor porpoise group size was 2.01 individuals ( $\mathrm{SE}=0.06, \mathrm{n}=634$ ), with a range of 1 to 18 harbor porpoise per group. There were five cow/calf pairs observed from June to October 1992.

Off Point Doughty, harbor porpoise were sighted in water with a mean depth of $138 \mathrm{~m}(\mathrm{SE}=1.37, \mathrm{n}=634)$. Generally, there were significantly $(\mathrm{p}<0.05)$ fewer numbers of harbor porpoise than expected in depths less than $125 \mathrm{~m}$ (except in depth category 76 to $100 \mathrm{~m})$ and significantly $(\mathrm{p}<0.05)$ greater numbers of harbor porpoise than expected in depths of 125 to $175 \mathrm{~m}$ (Fig. 17a).

The mean seafloor slope in the study area was $6.52 \%(\mathrm{SE}=0.64, \mathrm{n}=160$, range: $0.13 \%$ to $50 \%$ ). Harbor porpoise were sighted over a mean slope of $8.55 \%$ $(\mathrm{SE}=0.56, \mathrm{n}=634$, range: $0.23 \%$ to $183 \%$ ). As was the case with vessel surveys, a significantly greater than expected number of harbor porpoise also were observed in areas with 0 to $2 \%$ slope. There was great variability, however, in the occurrence of harbor porpoise in areas with different degrees of slope. There were significantly $(p<0.05)$ fewer numbers of harbor porpoise than expected in certain categories with moderate seafloor slope (4 - 6\%, 6-8\%, $12-14 \%)$, and significantly greater numbers of harbor porpoise than expected in categories with little slope $(0-2 \%)$, moderate slope $(8-10 \%)$ and greater seafloor slopes (>20\%; Fig. 17b). 
Significantly more harbor porpoise were sighted when tide rips were present than when rips were absent in $1991\left(\chi^{2}=9.45, \mathrm{n}=54, \mathrm{p}<0.05\right)$ and $1992\left(\chi^{2}=30.92, \mathrm{n}=633\right.$, $\mathrm{p}<0.05$; Fig. 18a).

Harbor porpoise were observed milling significantly more frequently than traveling in $1991\left(\chi^{2}=9.8, \mathrm{n}=54, \mathrm{p}<0.05\right)$ and $1992\left(\chi^{2}=7.92, \mathrm{n}=517, \mathrm{p}<0.05\right.$; Fig. 18b). Other harbor porpoise behaviors observed off Point Doughty and during boat surveys included: 1) logging (dorsal surface exposed from anterior blowhole to dorsal fin), duration of 2 to 10 seconds, observed on several occasions; 2) spyhopping (porpoise in vertical position, $1 / 4$ to $1 / 3$ of the body exposed); 3) vertical and horizontal leaps clear of the water; 4) high porpoising; and 5) pop-splashing (Scheffer and Slipp 1948, Taylor and Dawson 1984).

A mean of 1.1 boats $(\mathrm{SE}=0.13, \mathrm{n}=99$ ) were within $1 \mathrm{~km}$ of harbor porpoise sightings in 1991 and a mean of 0.3 boats $(\mathrm{SE}=0.02, \mathrm{n}=634)$ in 1992. No large aggregations $(>1000)$ of birds were sighted near harbor porpoise. No birds were sighted within $1 \mathrm{~km}$ of harbor porpoise during $71 \%(n=71)$ of survey days in 1991 and $59 \%$ $(n=372)$ in 1992. Smaller groups of birds $(<100)$ within $1 \mathrm{~km}$ of harbor porpoise were observed only $29 \%(n=29)$ of survey days in 1991 and $40.5 \%(n=256)$ in 1992 . No groups greater than 100 birds were observed within $1 \mathrm{~km}$ of harbor porpoise in 1991, and only $0.5 \%(n=4)$ of bird groups greater than 100 individuals were observed within $1 \mathrm{~km}$ of harbor porpoise in 1992.

\section{Shore-based Abundance Surveys}

Shore-based abundance surveys $(n=73)$ were conducted on twenty days within a $212^{\circ}$ viewing area $\left(16.68 \mathrm{~km}^{2}\right)$ from Point Doughty, Orcas Island, Washington (June to September 1992). Density (porpoise/ $\left.\mathrm{km}^{2}\right)$ was significantly different $(\mathrm{H}=13.103$, 
$\mathrm{p}<0.004, \mathrm{n}=73$ ) among months. Harbor porpoise densities were greatest in June (mean $=4.11$ porpoise $\left./ \mathrm{km}^{2}, \mathrm{SE}=0.52, \mathrm{n}=19\right)$ compared with July $(\mathrm{Q}=3.05, \mathrm{p}<0.05)$, August $(Q=2.64, p<0.05)$, and September $(Q=2.66, p<0.05 ;$ Fig. 19). Harbor porpoise densities were still significantly $(\mathrm{p}<0.05)$ greater than densities of porpoise in June, July, or August when data were reanalyzed omitting an unusually large concentration of harbor porpoise ( $\mathrm{n}=195$ individuals) observed in June. To standardize for differences in time of day among months, data were analyzed comparing only afternoons (1200 to $1600 \mathrm{~h}$ ), and densities in June remained significantly greater $(H=10.025, \mathrm{p}<0.018)$. Among July, August, and September, harbor porpoise densities were not significantly $(p>0.05)$ different.

Harbor porpoise group size (mean $=1.59$ individuals, $\mathrm{SE}=0.03, \mathrm{n}=1569$, range: 1 to 8) remained consistent during the four months of surveys (Fig. 20). A maximum 195 harbor porpoise were observed during a survey on 15 June 1992. During this survey, all harbor porpoise were traveling from northeast to the west and southwest. Seventy percent of those harbor porpoise sighted remained within the study area at least two hours, but as the wind increased in the afternoon, surveys were terminated.

Because of the variability in the number of hours between high and low tide each day off the San Juan Islands, the number of harbor porpoise observed per minute in relation to high and low tide were analyzed separately. There was no significant difference in mean number of harbor porpoise observed per minute among hours before or after low $(H=3.406, n=62, p=0.756$; Fig. 2la $)$ or high $(H=6.452, n=50, p=0.488 ;$ Fig. 2lb $)$ tides. There were significantly $(t=4.14, \mathrm{p}<0.05)$ more harbor porpoise observed per minute, however, during flood (mean $=1.18, \mathrm{SE}=0.20$ ) than ebb tides (mean $=0.60$, $\mathrm{SE}=0.16)$ 
Mean number of harbor porpoise observed per minute off Point Doughty was greatest in mid-morning $(1100 \mathrm{~h})$, less at midday $(1200 \mathrm{~h})$, and greatest again in mid-late afternoon ( 1400 to $1500 \mathrm{~h})$, but there was no significant $(\mathrm{H}=16.15, \mathrm{p}=0.064)$ difference among mean number of harbor porpoise observed per minute and each hour of daylight surveyed $(0800$ to $1800 \mathrm{~h}$ ). Mean number of harbor porpoise observed per minute was greatest two hours before each peak in the maximum flood tide (recorded from a current station near Point Doughty; Fig. 22). When all survey days $(\mathrm{n}=20)$ were combined, $43 \%$ of the maximum flood tides occurred between $1100 \mathrm{~h}$ and $1500 \mathrm{~h}$, and $48 \%$ occurred between $1600 \mathrm{~h}$ and $1800 \mathrm{~h}$.

A significant negative correlation $(r=-0.289, \mathrm{n}=73, \mathrm{p}<0.05)$ was found between number of harbor porpoise and number of boats within the survey area, however, little variability $\left(r^{2}=0.083\right)$ was explained by this relationship. Harbor porpoise were observed avoiding boats each sampling day. Harbor porpoise often $(>75 \%$ of the time) dove and resurfaced away from boats when boats passed directly through areas with harbor porpoise.

\section{DISCUSSION}

Population and density estimates of harbor porpoise were based on several assumptions of line transect theory. Relevant assumptions included: 1) study area was sampled randomly or animals were randomly distributed, 2) all animals were detected on the trackline and sighted at their initial locations, 3) group size was estimated without error, and 4) locations were measured accurately for each individual or group (Burnham et al. 1980). 
The first assumption of line transect theory was met by employing a stratified random sampling design within the study area. Barlow (1988) surveyed for harbor porpoise only nearshore (along the $18 \mathrm{~m}$ isobath) during vessel surveys off California, Oregon, and Washington, sighting harbor porpoise within a narrow strip $(<1 \mathrm{~km})$ of the trackline. Because harbor porpoise were distributed nonrandomly further from shore, Barlow (1988) reported surveys did not adequately cover harbor porpoise habitat. By randomly surveying within a defined study area off the northern San Juan Islands, all oceanographic features of interest (depth, seafloor slope, surface temperature) were adequately sampled.

The assumption that all animals are detected on the trackline is often violated during marine mammal surveys. Animals with long durations of submergence have a high probability of remaining undetected during the passage of an aircraft or vessel. Based on the time harbor porpoise are submerged, several studies of harbor porpoise have indicated the probability of detecting a harbor porpoise on the trackline, $g(0)$, to be less than one (Barlow 1988, Calambokidis 1991, Palka 1993). Barlow (1988) reported an estimated $22 \%$ of harbor porpoise that surfaced on the trackline were missed by a team of five observers (platform height $=10 \mathrm{~m}$ ) traveling on a vessel at $18.5 \mathrm{~km} / \mathrm{hr}$. Using three observers per survey, Calambokidis (1991) and Palka (1993) estimated the probability of observing a group of harbor porpoise on the trackline, $g(0)$, to be less than 0.5 . I assumed $g(0)$ was one during my study. My average boat speed $(9 \mathrm{~km} / \mathrm{hr})$ was slow enough that harbor porpoise with an average duration of submergence of two minutes (determined during this study) would have surfaced to breath at least once during the passage of the vessel. Because some harbor porpoise were submerged up to five minutes (Chapter 2) and only two observers were used per survey, possibly some harbor porpoise were not detected on the trackline, therefore underestimating harbor porpoise abundance. 
Detection of harbor porpoise before they become aware of the survey vessel is often difficult to determine without prior knowledge of their locations before passage of a survey vessel. Harbor porpoise are small, inconspicuous animals, which avoid boats (Amudin and Amudin 1974, Gaskin 1977, Prescott and Fiorelli 1980, Barlow 1988). Polacheck and Thorpe (1990) observed harbor porpoise swimming away from their survey vessel a significant proportion of time. Barlow (1988) reported harbor porpoise quickly avoided a closely approaching survey vessel. Vessel avoidance by harbor porpoise may result in animals remaining undetected by observers or may affect estimates of perpendicular distance of harbor porpoise from the vessel. No apparent vessel avoidance near the trackline was observed during this study. The frequency of harbor porpoise sightings was greatest near the vessel and decreased with increasing perpendicular distance from the vessel. Harbor porpoise were observed avoiding other vessels within the study area, however, submerging when a vessel was near and resurfacing elsewhere. It is possible, therefore, that harbor porpoise were not detected at their initial locations although observers made every effort to do so.

Data from land-based calibration studies indicated observers on vessels underestimated true group size of harbor porpoise, missing up to $60 \%$ or more of animals (Calambokidis et al. 1991). Average group sizes of harbor porpoise in this study were similar to those reported by Calambokidis $(1991 ; 1.74$ to 2.3 porpoise per group) along the outer coast of Washington and by Green et al. (1992; 1.46 porpoise per group) off California, Oregon, and Washington. Greater average harbor porpoise group sizes have been reported by Flaherty and Stark (1982;2.8 to 3.9 porpoise per group) during vessel surveys within Washington Sound and Barlow et al. (1988; 2.75 to 3.23 porpoise per group) during aerial surveys along the coast of California, Oregon, and Washington. 
Because the majority of harbor porpoise groups consisted of three or fewer animals during this study, and mean harbor porpoise group size detected from shore-based surveys (2.01 porpoise) was similar to vessel surveys (1.91 porpoise), I am confident in group size estimates.

Accurately measuring the locations of marine mammals from vessels can be affected by the height of observers above water (Polacheck and Smith 1989) and the proper use of reticle and compass binoculars (Smith 1982, Barlow and Lee 1994). When two different platform heights were compared, Polecheck and Smith (1989) reported greater densities of harbor porpoise from a higher observer platform. Although the platform height from my survey vessel was low $(2.68 \mathrm{~m})$, the lack of any ocean swell, optimal weather conditions, and observer consistency with reticle and compass binoculars contributed to the accuracy of sighting data.

Density estimates of harbor porpoise $\left(1.26\right.$ porpoise $\left./ \mathrm{km}^{2}\right)$ within the study area $\left(237 \mathrm{~km}^{2}\right)$ were greater than densities reported by Calambokidis et al. (1993b; 0.13 porpoise $/ \mathrm{km}^{2}$ ) for waters off the San Juan Islands and part of the Strait of Georgia $\left(2,148 \mathrm{~km}^{2}\right)$, but similar to density estimates of Flaherty and Stark $(1982 ; 0.85$ to 1.63 porpoise $\left./ \mathrm{km}^{2}\right)$ for the north and west San Juan Islands $\left(1,005 \mathrm{~km}^{2}\right)$. Green et al. (1992) surveyed an extensive area within the $100 \mathrm{~m}$ isobath off the coast of Oregon and Washington and also reported a much lower density of harbor porpoise $\left(0.17\right.$ porpoise $\left./ \mathrm{km}^{2}\right)$ than reported here. Surveys conducted by Green et al. (1992) and Calambokidis et al. (1993b) included regions of high and low harbor porpoise abundance, therefore, their estimates of harbor porpoise density were less than off the northern San Juan Islands. Because my main interest in this study was to determine harbor porpoise habitat use, I chose a study area where harbor porpoise were consistently sighted. Harbor porpoise were highly concentrated (2.66 to 4.11 porpoise $/ \mathrm{km}^{2}$ ) off Point Doughty, Orcas 
Island, Washington. The waters off Sitakaday Narrows, Glacier Bay, Alaska, an area similar to Point Doughty with strong currents and deep waters, had similar densities (1.2 to 5.9 porpoise $/ \mathrm{km}^{2}$; Taylor and Dawson 1982) as those off Point Doughty.

Estimated densities of harbor porpoise in this study, therefore, were similar to or greater than reported elsewhere.

Estimates of the effective strip width (ESW) and probability density function, f(0), which are related to sighting efficiency of observers, can be significantly affected by observer number and height above the water, vessel speed, and sea conditions. From a $52 \mathrm{~m}$ vessel with five observers, Barlow (1988) reported an ESW of $222 \mathrm{~m}$ and $\mathrm{f}(0)$ of $4.5 / \mathrm{km}$ when sea state was Beaufort 0 to 1 and an ESW of $143 \mathrm{~m}$ and $f(0)$ of $6.96 / \mathrm{km}$ during Beaufort 2. During vessel (32 $\mathrm{m}$ vessel) surveys in the Gulf of Maine, Palka (1993) estimated an ESW of $189 \mathrm{~m}$ and $\mathrm{f}(0)$ of $5.29 / \mathrm{km}$ when observers were $9 \mathrm{~m}$ above the water, and an ESW of $233 \mathrm{~m}$ and $\mathrm{f}(0)$ of $4.4 / \mathrm{km}$ when observers were $14 \mathrm{~m}$ above the water. Using a similar sized vessel $(11 \mathrm{~m})$ and observation platform $(4 \mathrm{~m})$ as this study, Calambokidis (1991) estimated an ESW of $211 \mathrm{~m}$ and $\mathrm{f}(0)$ of $4.74 / \mathrm{km}$ off the northern Washington coast. The greater estimated ESW (337 m) determined during this study was likely due to slow vessel speed and excellent sighting conditions (< Beaufort 2 with very little swell) during surveys. Barlow (1988), Barlow et al. (1988), and Forney et al. (1991) reported sightings of harbor porpoise were greatest during Beaufort 0 or 1 , and decreased with increasing sea state. Surveying only during optimal sighting conditions, however, can greatly reduce sample size (in this study, $44 \%$ of available days were not surveyed for harbor porpoise because of unfavorable weather conditions).

Large-scale movements of harbor porpoise have not been observed along the west coast of North America but encounter rates vary among regions. Off Oregon and Washington, harbor porpoise encounter rates were greatest in fall and winter, least in 
summer, and intermediate in spring (Green et al. 1992), although no seasonal movements of harbor porpoise have been observed between Oregon and Washington (Green et al. 1992). Numbers of harbor porpoise sighted in the southwestern Strait of Juan de Fuca, Washington were greatest in fall and least in spring (Calambokidis et al. 1987). Based on pollutants detected in harbor porpoise tissues, porpoise along the west coast do not travel great distances (Calambokidis and Barlow 1991). Harbor porpoise have significant genetic heterogeneity among regions in the northeast Pacific (Rosel et al., in press), which indicates harbor porpoise movements may be restricted.

Prey or habitat requirements often limit distribution of cetaceans to regions that may vary daily, seasonally, or yearly depending on an individual's foraging, mating, or behavioral requirements. Surveys were conducted only within the summer months during this study, which may have biased density estimates of harbor porpoise within the northern San Juan Islands. Flaherty and Stark (1982) sighted harbor porpoise during all months of the year off the San Juan Islands, but observed more harbor porpoise in summer months (June to August) than other times of the year. Surveys of harbor porpoise throughout the year along the east and west coasts of the United States have indicated a seasonal pattern among various regions (Neave and Wright 1968, Gaskin and Watson 1985, Barlow 1988, Green et al. 1992). Greatest numbers of harbor porpoise occurred in the Bay of Fundy during summer (June to September); harbor porpoise apparently moved offshore in winter (Neave and Wright 1968, Gaskin 1977). Harbor porpoise in the Gulf of Maine moved northward from April to July and southward in October (Kraus and Prescott 1984). Results of fixed transect surveys conducted in my study indicated no change in distributions of harbor porpoise between July and August 1991 and 1992. Clumped distribution of harbor porpoise along tracklines was likely associated with habitat features (harbor porpoise were sighted most often over deep water). 
Vessel and shore-based surveys were conducted during this study to answer questions about habitat use of harbor porpoise in large (northwestern San Juan Islands), and small areas (off Point Doughty, Orcas Island). During vessel surveys, observers examined a large region of varying habitat types, measured sea surface temperature, water clarity, and determined distribution and abundance of harbor porpoise. The boat-based study area was comprised of several depth and bathymetric features and great variation in number of harbor porpoise sightings along fixed transect surveys and per section (A - E). Each section of the study area (A - E), therefore, was examined individually. Additionally, shore-based surveys provided a platform in which harbor porpoise could be observed for long periods within a consistent area without affecting harbor porpoise behavior.

In both my land-based and vessel-based surveys, depth was a primary factor associated with the distribution of harbor porpoise. Harbor porpoise occurred proportionally more frequently in depths $>125 \mathrm{~m}$ and proportionally less in depths $<75 \mathrm{~m}$. Flaherty and Stark (1982) observed harbor porpoise over depths of 3.7 to $311 \mathrm{~m}$ within Washington Sound, but reported no pattern of harbor porpoise distribution in relation to depth. Within the Bay of Fundy, there was a positive correlation between harbor porpoise abundance and depth and physiographic features, which concentrated herring (Watts and Gaskin 1985). Harbor porpoise in the Bay of Fundy were less abundant in shailow water $(<10 \mathrm{~m})$ due to turbulence from extreme currents (Watts and Gaskin 1985). Although currents off the northern San Juan Islands are not as rapid as in the Bay of Fundy, harbor porpoise were seldom observed in shallow water $(<25 \mathrm{~m})$, possibly due to the lack of prey resources in these areas.

Among island regions such as the Bay of Fundy, Glacier Bay, and off the San Juan Islands, harbor porpoise are more often associated with deeper waters than along coastal regions of North America. Most harbor porpoise observed off the coast of California, 
Oregon, and Washington occurred at shallow water depths, and sightings decreased with increasing depth (LaBarr and Ainley 1985, Barlow 1988, Dorfman 1990, Calambokidis 1991). Incidental net entanglement of harbor porpoise within Washington waters occurred at the bottom of nets, at depths of 73 to $81 \mathrm{~m}$ (Scheffer and Slipp 1948), and near the bottom or in the lower one-half of nets set to 11 to $18 \mathrm{~m}$ deep, indicating porpoise were foraging along the bottom or in deeper areas of the net (Gearin et al. 1991). The depth of water where harbor porpoise were sighted in this study may have been due to occurrence of prey within these areas.

Harbor porpoise feed on a wide variety of prey including northern anchovy, market squid, night smelt (Spirinchus starksi; Morejohn et al. 1978, Dorfman 1990), juvenile rockfish, Pacific hake, Pacific tomcod (Jones 1981), spotted cusk eel (Chilara taylori; Sekiguchi 1987), shad (Scheffer and Slipp 1948), herring, whiting (Theragra chalcogramma), and capelin (Mallotus villosus; Rae 1973, Recchia and Read 1989, Gearin and Johnson 1991). The dominant prey items in stomachs of harbor porpoise taken in a setnet fishery from June to September 1988 and 1989 off Spike Rock, Washington were Pacific herring, market squid, gadids, and osmerids (Gearin and Johnson 1991). The lengths of these prey items corresponded to juvenile age classes (Hart 1973, Hixon 1983). Discrete populations of spawning adults, juvenile stocks, and migrating populations of immature and adult Pacific herring occur in northern Puget Sound (Lemberg 1978).

The Strait of Georgia herring population is the largest known in Washington state, and herring are quite abundant in sections of the eastern Strait during summer, fall, and winter months (Lemberg 1978). Harbor porpoise, harbor seals, and a minke whale were observed feeding on Pacific herring off Flattop Island during this study. Harbor seals using Smith Island, Washington (southern Washington Sound) also fed on herring in 
summer (Calambokidis et al. 1978). The occurrence of Pacific herring in northern Puget Sound and my observations of harbor porpoise foraging on herring indicate herring may be an important prey item of harbor porpoise off the northern San Juan Islands.

Pacific herring and market squid vertically migrate within the water column, remaining closer to the seafloor during the day, and approaching the surface at night (Hart 1973, Flaherty and Stark 1982, Blaxter 1985). These prey habits may explain harbor porpoise distribution over deeper waters during the day. Harbor porpoise that were milling were not associated with large aggregations of birds (commonly observed feeding on prey at the surface), indicating harbor porpoise might have been feeding at depth. Smith and Gaskin (1983) stated that presence or absence of fish within the Bay of Fundy probably determined the immediate distribution of mother-calf pairs of harbor porpoise.

It is possible that harbor porpoise feed at depth during the day because they are not actively foraging at night. Studies of radio-tagged harbor porpoise in the Bay of Fundy indicated harbor porpoise were relatively inactive at night (midnight to 0600) and active during the day. If harbor porpoise off the northern San Juan Islands were relatively inactive at night, as harbor porpoise are in the Bay of Fundy, their high energy requirements would compel them to actively feed during the day. Sergeant (1969) reported the feeding rate of captive harbor porpoise was $10 \%$ of body weight per day. With these high energy demands, prey may be a primary factor governing the distribution of harbor porpoise off the San Juan Islands. Based on pollutant concentrations reported for harbor porpoise off the west coast of North America, individuals may remain in one area, feeding largely on local fish stocks, rather than on highly migratory fish as in the Bay of Fundy (Calambokidis et al. 1987). 
In this study, harbor porpoise were sighted most often in shallow sloping areas, with little bathymetric relief. These results contrast with those of Flaherty and Stark (1982) in which $70 \%$ of harbor porpoise sighted were in areas with seafloor relief greater than $40 \%$. Comparisons were difficult because Flaherty and Stark (1982) did not define seafloor relief measurements. Calambokidis (1991) observed significantly more harbor porpoise than expected within areas of uneven bottom topography off the outer Washington coast, but reported results probably were related to harbor porpoise association with shallower water, where an uneven seafloor was more common. Off the northern San Juan Islands, deeper waters were associated with gradual seafloor slopes rather than areas of high bathymetric relief.

Another influence on harbor porpoise distribution is water temperature. Calambokidis (1991) reported harbor porpoise sightings in water temperatures ranging from $9^{\circ}$ to $16^{\circ} \mathrm{C}$ off Washington. In the Bay of Fundy, Watts and Gaskin (1985) found a negative correlation between harbor porpoise abundance and mean August surface temperature and Watson (1981) reported harbor porpoise occurred in water temperatures less than $15^{\circ} \mathrm{C}$. It is unlikely, though, that sea surface temperature alone would influence harbor porpoise distribution. Most harbor porpoise entered Fish Harbor, New Brunswick, Canada when surface temperatures were between $9^{\circ}$ and $10^{\circ} \mathrm{C}$, which also coincided with large numbers of juvenile herring entering the region (Gaskin and Watson 1985). Within the Bay of Fundy, Watts and Gaskin (1985) found herring associated with vertically mixed waters, and reduced surface temperatures. This association was possibly due to increased concentrations of zooplankton, which also occurred along convergent zones (Watts and Gaskin 1985). Sea surface temperatures off the northern San Juan Islands, therefore, were possibly related to currents, which may have concentrations of harbor porpoise prey. 
Seasonal fluctuations in water temperature also may influence harbor porpoise distribution. In the Bay of Fundy, harbor porpoise exhibit an inshore - offshore migration (Neave and Wright 1968), possibly due to fluctuations in water temperature between winter and summer (Gaskin 1977). The large aggregation of harbor porpoise $(n=195)$ observed during this study may have been migrating through the study area in response to oceanographic changes; all porpoise were moving in the same direction at a moderate to fast speed. Calambokidis et al. (1985) also reported 50 to 100 harbor porpoise on 17 May and 9 June 1984 within northern Presidents Channel, near Point Doughty, Orcas Island, Washington. Water flow of the Fraser River, north of the San Juan Islands, is usually greatest in June (Kozloff 1973). The greater density of harbor porpoise off Point Doughty in June may have been due to the effects of the Frazer River runoff, which may influence currents, surface temperature, salinity, and fish populations off the northern San Juan Islands.

In this study, surface temperatures were measured along tracklines, and may not have represented water temperatures where harbor porpoise were sighted. Tide rips mixing water, or currents moving through the study area could have altered water temperatures by a few degrees between trackline and harbor porpoise location. Surface temperatures from beginning to end of the $8-\mathrm{km}$ tracklines varied from $0.5^{\circ}$ to $5.5^{\circ} \mathrm{C}$. I assumed, however, it was less biased to collect surface temperatures along the trackline than continuously go off transect and potentially disturb harbor porpoise ahead of the vessel.

Tidal currents also may affect the distribution of harbor porpoise. Within the vicinity of Point Doughty, Orcas Island, harbor porpoise were concentrated over deep waters, shallow slopes, and during flood tides. Taylor and Dawson (1984) observed more harbor porpoise during high tide than low tide in Sitakaday Narrows, Glacier Bay, Alaska, 
an area composed of clear deep waters and strong currents. More harbor porpoise appeared to move inshore during flood tide and offshore during ebb tide in the Bay of Fundy (Watson 1976, Gaskin and Watson 1985) and in Monterey Bay, California (Sekiguchi 1987). Scheffer and Slipp (1948) reported more harbor porpoise were caught in salmon traps stationed in areas of rapid currents, and Gaskin et al. (1985) reported radio-tagged harbor porpoise, moving through major channels and passages, always swam in the direction of tidal flow.

Harbor porpoise occurred in greater numbers in the presence, rather than the absence, of tide rips off Point Doughty, Orcas Island. Tide rips occur in incoming or outgoing tidal currents of steady direction, often in the presence of a rapid current (Barenblatt et al. 1985). Miller (1989) often observed Dall's porpoise in tide rips and Suryan (1995) reported harbor seals foraged among tide rips. Calambokidis et al. (1987) noted the association of harbor porpoise with tide rips and Everitt et al. (1980) reported harbor porpoise were frequently observed "working" tide rips in apparent search for prey. Flaherty and Stark (1982) observed $72 \%$ of harbor porpoise sighted in or near tide rips or where tide rips normally occurred. In this study, harbor porpoise were observed more often in the absence of tide rips during boat surveys but in the presence of tide rips during shore-based surveys. Because tide rips were only recorded when harbor porpoise were sighted, however, results may have been biased. Recording tide rips on a continuous basis during surveys would provide an improved comparison between the presence of harbor porpoise in relation to the availability of tide rips. The occurrence of strong tide rips off Point Doughty may be an important factor influencing the high densities of harbor porpoise in that region. Tide rips may be a primary factor in concentrating zooplankton, which fishes feed on, therefore concentrating harbor porpoise, which feed on fishes. Unfortunately, information on the relationship between tide rips and prey resources is 
lacking. Because prey resources appear to be abundant in the presence of tide rips, it would be useful to determine if prey concentrate in tide rips.

Harbor porpoise distribution in relation to time of day has been well documented (Flaherty and Stark 1982, Sekiguchi 1987, Dahlheim et al. 1991). As in my study, Dahlheim et al. (1991) reported that in southeast Alaska, most harbor porpoise sightings occurred in mid-morning and late afternoon and less during midday. Sekiguchi (1987) observed more harbor porpoise in morning than afternoon in Monterey Bay, California. In contrast, Flaherty and Stark (1982) observed more harbor porpoise during midday in Washington Sound. It is doubtful that time of day had a significant effect on the ability to sight harbor porpoise in this study, therefore, other environmental factors must have affected harbor porpoise in relation to time of day. Occurrence of harbor porpoise appears closely associated with the strength of tidal currents. From June to October 1992, the majority of low tides in the northern San Juan Islands occurred in the early morning hours, causing most of the surveys to be conducted during flood tides. The contrasting results of my study with those of Flaherty and Stark (1982), who conducted surveys throughout the year off the San Juan Islands, likely result from seasonal changes in diel tide cycles. Tide cycles, therefore, should be examined when relating harbor porpoise sightings to time of day.

There was a high concentration of harbor porpoise during all months surveyed in 1991 and 1992 off Point Doughty, Orcas Island. Milling, which is often a behavior associated with foraging, was observed significantly more than traveling behavior from Point Doughty. The association of harbor porpoise with deep water, flood tides, and tide rips off Point Doughty may be related to the occurrence of prey within this area. The relationship between the occurrence of harbor porpoise with tide and time of day indicated harbor porpoise movements may have been associated with concentrations of prey in flood 
currents and tide rips. Read and Gaskin (1985) radio-tagged harbor porpoise in the Bay of Fundy and found harbor porpoise moved 15 to $20 \mathrm{~km}$ in a 24-hr period. One harbor porpoise used a home range of $210 \mathrm{~km}^{2}$, remaining within a portion of an area for a few days, then moving into another area for a similar period of time (Read and Gaskin 1985). It is possible that harbor porpoise range throughout the San Juan Island waters but continue to return to waters off Point Doughty as a primary foraging area.

Because harbor porpoise apparently have vacated southern Puget Sound waters: determining present population size of harbor porpoise off northern Washington is important. Calambokidis et al. (1993b) estimated the population size of harbor porpoise for the inland waters and west coast of Washington. The intensive surveys I conducted in an area of relatively high harbor porpoise concentrations should be valuable for comparisons with future estimates in this area. Determining abundance of harbor porpoise as well as habitat variables, which may influence porpoise distribution in the inland waters of northern Washington waters, may help us understand why harbor porpoise populations have declined in southern Puget Sound. 


\section{CHAPTER 2: RESPIRATION PATTERNS}

\section{INTRODUCTION}

Respiration patterns of cetaceans have been analyzed to determine energetic or metabolic requirements (Sumich 1994), behavioral changes due to natural or humaninduced disturbances such as boat traffic (Amudin and Amudin 1974, Gaskin 1977, Baker et al. 1982, Watkins 1986), and to develop correction factors for number of animals missed during aerial surveys (Barlow et al. 1988, Calambokidis et al. 1993a). Kraus et al. (1983) reported observers in aircraft saw only $14 \%$ of harbor porpoise groups known to be present, based on shore-based observers. Barlow et al. (1988) noted harbor porpoise were visible from a helicopter during short duration dives $(<30 \mathrm{sec})$, but were not visible during long (> $30 \mathrm{sec}$ ) duration dives. Using this information, Barlow et al. (1988) developed a correction factor by determining the fraction of time harbor porpoise were visible to observers during aerial surveys. Comparing the sighting success of aerial observers to that of harbor porpoise groups tracked from land, Calambokidis et al. (1993a) developed a correction factor similar to Barlow et al. (1988), and determined a variance for the correction factor.

Cetaceans often exhibit different respiration patterns when traveling, resting, or feeding. Watson and Gaskin (1983) recognized two basic respiration patterns of freeranging harbor porpoise in the Bay of Fundy: 1) short durations of submergence, exhibited by traveling animals (pattern A); and 2) series of breaths followed by a long submergence, usually exhibited by animals feeding (pattern B). Harbor porpoise respiration rates recorded off Oregon (Barlow et al. 1988), and in Glacier Bay, Alaska (Taylor and Dawson 1984), corresponded to pattern B. 
Many species of cetaceans have been individually identified by coloration patterns or scars on their bodies, allowing researchers to observe respiration patterns of specific individuals. Killer whales (Bigg et al. 1987, Heimlich-Boran 1987) have been identified by nicks or scars on their dorsal fins and coloration patterns of their saddle patches. Scars and shape of the dorsal fin identify individual bottlenose dolphins (Würsig and Würsig 1977). Using these marks, researchers have been able to determine respiration patterns of individuals. Harbor porpoise, however, are often difficult or impossible to identify individually because they are small, fairly nondescript, and difficult to follow for long periods of time. Respiration rates of harbor porpoise, therefore, often reflect a group of harbor porpoise and not individuals.

The primary objectives of this study were to: 1) determine respiration patterns of harbor porpoise individuals and groups off northern Washington for development of a correction factor for abundance estimation; and 2) determine individual variation in duration at surface and duration of dives.

\section{METHODS}

Harbor porpoise respiration data were collected ( 20 hours of which 8 hours were used in analysis) from June to August 1991 and June to October 1992 either from a small vessel with the motor off or from Point Doughty, Orcas Island, Washington (Fig. 4), with a viewing area of $240^{\circ}$. Observers used $7 \times 50$ Fujinon reticle and compass binoculars or the naked eye during observations. Respiration data primarily were collected during observations of individual harbor porpoise, and secondarily of harbor porpoise groups. When an individual or group of harbor porpoise was sighted, each duration at surface, duration of dive, and behavior was recorded. Duration of time an individual occurred at 
or below the surface was recited aloud by an observer, while a second observer recorded time on a data sheet and a portable cassette tape recorder.

Correction factors for aerial surveys were calculated using methods reported by Barlow et al. (1988). The probability that a harbor porpoise was at the surface of the water during the passage of an aircraft was calculated as:

$$
\mathrm{Pv}=\frac{\mathrm{s}+\mathrm{t}}{\mathrm{s}+\mathrm{d}}
$$

where $\mathrm{Pv}=$ the probability of a porpoise being visible, $\mathrm{s}=$ average duration at or near the surface, $t=$ duration of time within visual range of an observer, and $d=$ average duration below the surface (Barlow et al. 1988). The probability of not observing a submerged animal was equal to $1 / \mathrm{Pv}$.

A breath series was defined as a series of shore duration dives $(<30 \mathrm{sec})$, preceded and followed by a greater duration $(>30 \mathrm{sec})$ dive. Data analysis included only complete (every breath at the surface was recorded) breath series. By dividing the average breath series time by the total time (average breath series time plus average dive time), the average time a harbor porpoise was at or near the surface was determined.

The number of times per minute an individual surfaced to breathe was calculated for individual and groups of harbor porpoise. I observed mainly individual harbor porpoise to obtain a more accurate estimate of individual variation in duration at surface and duration of dives. Calves surface to breathe a greater number of times per minute than adult harbor porpoise (Watson and Gaskin 1983, Taylor and Dawson 1984); therefore, data involving calves were not used in analyses. 


\section{RESULTS}

Mean duration of dives less than $30 \mathrm{sec}$ was $6.6 \mathrm{sec}(\mathrm{SE}=0.11, \mathrm{n}=1,551)$ for individual and harbor porpoise groups combined $(n=95)$. Mean duration of dives greater than $30 \mathrm{sec}$ was $125 \mathrm{sec}(\mathrm{SE}=5.32, \mathrm{n}=156)$, and the maximum was $5.15 \mathrm{~min}$ (Table 3 ).

There were 169 breath series recorded for 76 individuals/groups of harbor porpoise. Within a breath series, $87 \%$ of the dives between breaths were less than $15 \mathrm{sec}$ apart (Fig. 23). The mean duration of a breath series was $51 \sec (\mathrm{SE}=2.48, \mathrm{n}=169)$ for all individuals and groups (Table 3). Harbor porpoise occurred at or near the surface an average $29 \%$ of the time. Using the probability formula developed by Barlow et al. (1988), the probability of a harbor porpoise being observed at or near the surface by an aircraft with a viewing time of 9 seconds and a speed of $160 \mathrm{~km} / \mathrm{h}$ (Barlow et al. 1988) would be $0.34(34 \%)$. An aerial census, therefore, would underestimate the population of harbor porpoise by a factor of 2.94 .

When respiration data of single harbor porpoise (i.e. not with other porpoise) were analyzed ( $n=3.45$ hours of respiration data), the mean duration of dives less than $30 \mathrm{sec}$ was $8 \mathrm{sec}(\mathrm{SE}=.20, \mathrm{n}=466)$ and the mean duration of dives greater than $30 \mathrm{sec}$ was $117 \mathrm{sec}(\mathrm{SE}=6.38, \mathrm{n}=73)$, maximum was $4.6 \mathrm{~min}$. The mean duration of a breath series was $45 \sec (S E=3.44, n=74$; Table 3). Single harbor porpoise surfaced to breathe an average 6.7 times ( $S E=0.54, n=47$, range: 1 to 18 ) during a breath series (Table 3 ). Single harbor porpoise were at the surface an average of $28 \%$ of the time. The probability of a single harbor porpoise being visible at or near the surface by a passing aircraft was $0.33(33 \%)$, therefore underestimating the population of harbor porpoise by a factor of 3.03 . 
Mean number of times harbor porpoise surfaced to breathe varied greatly depending on group (e.g. three porpoise were visible at the water's surface more often than an individual porpoise) and sample size. Mean breath rate (the number of times porpoise were visible at the surface) was 2.9 breaths $/ \min (\mathrm{SE}=0.22, \mathrm{n}=161)$ for a single harbor porpoise, 3.2 breaths $/ \mathrm{min}(\mathrm{SE}=0.34, \mathrm{n}=117)$ for groups of two harbor porpoise, 4.9 breaths $/ \min (\mathrm{SE}=0.6, \mathrm{n}=68)$ for groups of three, and 4.5 breaths $/ \min (\mathrm{SE}=1.4$, $n=15$ ) for groups of four. The mean number of breaths per minute for single harbor porpoise and groups overall was 3.4 breaths $/ \min (S E=0.19, \mathrm{n}=361$, range: 0 to 18$)$.

\section{DISCUSSION}

Gathering respiration data can be an important tool in assessing many aspects of cetacean populations. Because cetaceans spend the majority of their lives underwater, reporting population estimates without including duration of submergence would be biased and inaccurate. Barlow et al. (1988) first used respiration rates of harbor porpoise to correct for the number of animals missed by observers during aerial surveys, and Calambokidis et al. (1993a) recently calculated similar values.

Using mean duration of dives recorded during breath series for three studies ( $n=52$ groups), Barlow et ai. (i988) determined the mean duration of a harbor porpoise breath series was $30 \mathrm{sec}(\mathrm{SE}=1.95)$ and the mean duration of dives was $95.8 \mathrm{sec}$ $(\mathrm{SE}=5.32)$. The percentage of time at or near the surface was $23.9 \%$. A mean duration of a breath series of $36 \mathrm{sec}(\mathrm{SD}=13.1)$ and mean duration of dive of $127 \mathrm{sec}(\mathrm{SD}=31.0)$ was recorded for seven harbor porpoise groups monitored by Calambokidis et al. (1993a). These seven groups were at or near the surface from $14 \%$ to $33 \%$ of observation time. Mean duration at or near the surface (29\%) of 95 harbor porpoise individuals/groups 
within this study was similar to results reported by Barlow et al. (1988) and Calambokidis et al. (1993a).

Harbor porpoise would be visible from an aircraft $34 \%$ of the time off the northern San Juan Islands, compared to 31\% reported by Barlow et al. (1988) for data collected off California, Oregon, and Alaska, and $28 \%$ by Calambokidis et al. (1993a) off the northern San Juan Islands. The reason harbor porpoise were visible for a greater period of time off the northern San Juan Islands, was likely due to the greater duration of breath series $(50.95 \mathrm{sec})$ compared with $30 \mathrm{sec}$ reported by Barlow et al. (1988) and $36 \mathrm{sec}$ by Calambokidis et al. (1993a). Longer breath series and longer dives of harbor porpoise may be related to foraging at greater depths.

Unlike Watson and Gaskin (1983), who were able to observe harbor porpoise (some individually identified) for long periods of time, it was very difficult to gather longterm observations within this study area. When an attempt was made to obtain respiration data from a vessel, even with the motor off, harbor porpoise often immediately vacated the area. Most of the observations were conducted from shore (Point Doughty, Orcas Island) which had excellent viewing conditions. Because this area had a high density of harbor porpoise, however, and several groups were moving in and out of the area throughout the day, it was difficult to follow an individual or group for long periods of time.

Barlow et al. (1988) and Calambokidis et al. (1993a) were able to record respiration data for long time periods, but only from a small number of groups. Additionally, most researchers record respiration data of harbor porpoise groups, not individuals. The mean number of breaths observed per minute can vary greatly depending on group and sample size of harbor porpoise. Although respiration rates of harbor porpoise groups are useful in determining "average" breath series and durations of dives of harbor porpoise, information on individual variation in dive and surface intervals 
commonly is not obtained. Unfortunately, harbor porpoise are very difficult to identify individually; therefore, when respiration data is collected on groups of harbor porpoise, results can only reflect the group as a whole and not individuals. Perhaps, with additional studies observing harbor porpoise individuals, or identifiable individuals within a group, we may obtain a more accurate estimate of harbor porpoise respiration patterns. 


\section{CONCLUSIONS}

Within the northern San Juan Islands, Washington, harbor porpoise exhibited a patchy distribution, occurring primarily over deep waters, shallow seafloor slopes, and in water with surface temperatures $<16.3^{\circ} \mathrm{C}$. Sightings of harbor porpoise were common during boat and shore-based surveys, and distribution was consistent between 1991 and 1992. High concentrations of harbor porpoise were observed off Point Doughty, Orcas Island. The abundance of harbor porpoise in relation to deep waters, flood tides, and tide rips off Point Doughty, Orcas Island, may indicate that waters off Point Doughty are important foraging areas for harbor porpoise.

Dive characteristics (surface and dive intervals) were consistent with other studies of harbor porpoise conducted along the west coast of the United States. Respiration patterns of individual harbor porpoise were the first collected off the San Juan Islands.

This information is useful for comparisons with individuals from other regions, particularly shallow water areas, where porpoise may not dive as deep for prey, and may have shorter submergence periods.

Determining requirements, both biological and physical, of harbor porpoise in a dynamic environment is difficult, but an essential component in understanding the distribution of harbor porpoise within specific habitats. Results of this study present only information on harbor porpoise distribution in relation to environmental factors from June to October. The difficulty in sighting and individually identifying harbor porpoise presents another problem in determining movements and use of specific areas. Determining prey requirements of harbor porpoise off the San Juan Islands, specifically the waters surrounding Point Doughty, would help in determining why harbor porpoise are concentrating in certain areas. Radio tag studies of harbor porpoise, mapping tide rips, 
and conducting hydroacoustic prey surveys within the northern San Juan Islands would assist in answering many of the questions regarding the spatial patterns, activities, and habitat requirements of harbor porpoise in Washington waters. 


\section{LITERATURE CITED}

Amudin, M., and B. Amudin. 1974. On the behaviour and study of the harbour porpoise, Phocoena phocoena, in the wild. pp. 317-328. In G. Pilleri (Ed.), Investigations on Cetacea. Vol. V. Himanatomische Institut der Universitat, Berne.

Baker, S.C., L.M. Herman, B.G. Bays, and W.F. Stifel. 1982. The impact of vessel traffic on the behavior of humpback whales in Southeast Alaska. Contract No. 81ABC-00114 prepared for NMFS, NMML, 7600 Sand Point Way N.E. Bldg. 32, Seattle, WA 98115. 39pp.

Ballance, L.T. 1987. Ecology and behavior of the bottlenose dolphin, Tursiops truncatus, in the Gulf of California, Mexico. M.S. thesis, Moss Landing Marine Laboratories. 100pp.

Barenblatt, G.I., I.A. Leykin, A.S. Kaz'min, V.A. Kozlov, V.A. Razzhivin, I.A. Filippov, I.D. Frovlov, and S.I. Chuvil'chikov. 1985. Rips in the White Sea. Suloy v Belom more. Doklady Akademii Nauk SSSR. 281(6):1435-1439.

Barlow, J. 1988. Harbor porpoise, Phocoena phocoena, abundance estimation for California, Oregon, and Washington: I. Ship surveys. Fish. Bull. 86(3):417-432.

Barlow, J., and K.A. Forney. 1994. An assessment of the 1994 status of harbor porpoise in California. NOAA Tech. Mem. NMFS, NOAA, La Jolla, CA 92038. 17pp.

Barlow, J., and T. Lee. 1994. The estimation of perpendicular sighting distance on SWFSC research vessel surveys for cetaceans: 1974 to 1991. NOAA Tech. Mem. NMFS, NOAA, La Jolla, CA 92038. 46pp.

Barlow, J., C.W. Oliver, T.D. Jackson, and B.L. Taylor. 1988. Harbor porpoise, Phocoena phocoena, abundance estimation for California, Oregon, and Washington: II. Aerial surveys. Fish. Bull. 86(3):433-444.

Barlow, J., R.W. Baird, J.E. Heyning, K. Wynne, A.M. Manville II, L.F. Lowry, D. Hanan, J. Sease, and V.N. Burkanov. 1994. A review of cetacean and pinniped mortality in coastal fisheries along the west coast of the USA and Canada and the east coast of the Russian Federation. Rep. Int. Whal. Commn. (Special Issue 15):405425 .

Bigg, M.A., G.M. Ellis, J.K.B. Ford, and K.C. Balcomb. 1987. Killer Whales. A study of their identification, genealogy, and natural history in British Columbia and Washington State. Phantom Press, Nanaimo, British Columbia. 79pp. 
Blaxter, J.H.S. 1985. The herring: a successful species? Can. J. Fish. Aquat. Sci. 42 (suppl. 1):21-30.

Buckland, S.T., D.R. Anderson, K.P. Burnham, and J.L. Laake. 1993. Distance Sampling: Estimating abundance of biological populations. Chapman and Hall, New York, USA. 446pp.

Bumham, K.P., D.R. Anderson, and J.L. Laake. 1980. Estimation of density from line transect sampling of biological populations. Wildlife Monographs 72:1-202.

Calambokidis, J. 1991. Vessel surveys for harbor porpoise off the Washington coast. In H. Kajimura (Ed.). Harbor porpoise interactions with Makah Salmon set net fishery in coastal Washington waters, 1988-89. National Marine Mammal Laboratory Processed Report. National Marine Mammal Laboratory, 7600 Sand Point Way NE, Seattle, WA 98115-0070.

Calambokidis, J. and J. Barlow. 1991. Chlorinated hydrocarbon concentrations and their use for describing population discreteness in harbor porpoises from Washington, Oregon, and Califormia. In J.E. Reynolds III and P.K. Odell (eds.). Marine mammal strandings in the United States: Proceedings of the second marine mammal stranding workshop Miami, FL Dec. 3-5, 1987. NOAA Tech. Rep. NMFS 98:101-110.

Calambokidis, J., K. Bowman, S. Carter, J. Cubbage, P. Dawson, T. Fleischner, J. Schuett-Hames, J. Skidmore, and B. Taylor. 1978. Chlorinated hydrocarbon concentrations and the ecology and behavior of harbor seals in Washington State waters. Evergreen State College, Olympia, WA. 121pp.

Calambokidis, J., J. Peard, G.H. Steiger, J.C. Cubbage, and R.L. DeLong. 1984. Chemical contaminants in marine mammals from Washington state. NOAA Tech. Memo., NOS OMS 6. 167pp.

Calambokidis, J., S.M. Speich, J. Peard, G.H. Steiger, J.C. Cubbage, D.M. Fry, and L.J. Lowenstine. 1985. Biology of Puget Sound marine mammals and marine birds: Population health and evidence of pollution effects. NOAA Tech. Memo., NOS OMA 18, 159pp.

Calambokidis, J., G.H. Steiger, and J.C. Cubbage. 1987. Marine mammals in the Southwestern Strait of Juan de Fuca; natural history and potential impacts of harbor development in Neah Bay. Final Rept. To Army Corps of Engineers, Seattle, Washington, contract \#DACW67-85-M-0046. $103 \mathrm{pp}$. 
Calambokidis, J., S.R. Melin, and D.J. Rugh. 1991. Land-based calibrations of harbor porpoise sightings from a vessel along the northern Washington coast. In $\mathrm{H}$.

Kajimura (Ed.). Harbor porpoise interactions with Makah Salmon set net fishery in coastal Washington waters, 1988-89. National Marine Mammal Laboratory Processed Report. National Marine Mammal Laboratory, 7600 Sand Point Way NE, Seattle, WA 98115-0070.

Calambokidis, J., J.R. Evenson, J.C. Cubbage, P.J. Gearin, and S.D. Osmek. 1992. Harbor porpoise distribution and abundance off Oregon and Washington from aerial surveys in 1991. Final Report to NOAA, NMFS, National Marine Mammal Laboratory, Seattle, WA. 44pp.

Calambokidis, J., J.R. Evenson, J.C. Cubbage, S.D. Osmek, D. Rugh, and J.L. Laake. 1993a. Final Report: Calibration of sighting rates of harbor porpoise from aerial surveys. Contract 43ABNF202319, NOAA, NMFS, National Marine Mammal Laboratory, Seattle, WA. 4lpp.

Calambokidis, J., J.C. Cubbage, J.R. Evenson, S.J. Jeffries, and R.F. Brown. 1993b. Abundance estimates of harbor porpoise in Washington and Oregon waters. Final Report to NOAA, NMFS, National Marine Mammal Laboratory, Seattle, WA. 55pp.

Dahlheim, M., A. York, J. Waite, and C. Goebel-Diaz. 1991. Abundance and distribution of harbor porpoise (Phocoena phocoena) in Southeast Alaska, Cook Inlet and Bristol Bay, Alaska. Annual Report to MMPA, Office of Protected Species, NMFS, NMML, 1335 E. West Hwy., Silver Spring, Maryland 20910.

Dohl, T.P., R.C. Guess, M.L. Duman, and R.C. Helm. 1983. Cetaceans of central and northern California, 1980-1983: status, abundance, and distribution. Contract Rep. to Minerals Mgmt. Serv., USDI. 269pp.

Dorfman, E.J. 1990. Distribution, behavior, and food habits of harbor porpoises (Phocoena phocoena) in Monterey Bay. M.S. Thesis, Moss Landing Marine Laboratories. $57 \mathrm{pp}$.

Evans, P.G.H. 1987. The natural history of whales and dolphins. Facts on file, inc. $343 \mathrm{pp}$.

Everitt, R.D., C.H. Fiscus, and R.L. DeLong. 1979. Marine mammals of northern Puget Sound and the Strait of Juan de Fuca: a report on investigations November 1, 1977 to October 31, 1978. U.S. Dep. Commer., NOAA Tech. Memo. ERL MESA-41. Environ.-Res. Lab., Boulder, Colo., Jan. 1979. 191pp. 
Everitt, R.D., C.H. Fiscus, and R.L. DeLong. 1980. Northern Puget Sound marine mammals. EPA-600/7-80-139. NOAA, NMFS, National Marine Mammal Laboratory, Seattle, WA. 134pp.

Flaherty, C. and S. Stark. 1982. Harbor porpoise (Phocoena phocoena) assessment in "Washington Sound". Final Report for Subcontract 80-ABA-3584, NOAA, NMFS, National Marine Mammal Laboratory, Seattle, WA. 84pp.

Forney, K.A., D.A. Hanan, and J. Barlow. 1991. Detecting trends in harbor porpoise abundance from aerial surveys using analysis of covariance. Fish Bull. 89:(367-377)

Gaskin, D.E. 1977. Harbour Porpoise Phocoena phocoena (L.) in the western approaches to the Bay of Fundy 1969-75. Rep. Int. Whal. Commn. 27:487-492.

Gaskin, D.E. 1984. The harbor porpoise Phocoena phocoena (L.): regional populations, status, and information on direct and indirect catches. Rep. Int. Whal. Comm. 34 SC/35/SM 24:569-586.

Gaskin, D.E. and A.P. Watson. 1985. The harbor porpoise, Phocoena phocoena, in Fish Harbour, New Brunswick, Canada: occupancy, distribution, and movements. Fish. Bull. 83(3):427-442.

Gaskin, D.E., P. Arnold, and A. Blair. 1974. Phocoena phocoena. Mammalian species. 42:1-8.

Gaskin, D.E., A.J. Read, P.F. Watts, and G.J.D. Smith. 1985. Population dispersal, size, and interactions of harbour porpoises in the Bay of Fundy and Gulf of Maine. Can. Tech. Rep. Fish. Aqu. Sci. 1291. 28pp.

Gearin, P.J., and M.A. Johnson. 1991. Prey identified from stomachs of harbor porpoise and Chinook Salmon from the 1988-89 Makah Salmon Set-Net Fishery. In H. Kajimura (Ed.). Harbor porpoise interactions with Makah Salmon set net fishery in coastal Washington waters, 1988-89. National Marine Mammal Laboratory Processed Report. National Marine Mammal Laboratory, 7600 Sand Point Way NE, Seattle, WA 98115-0070.

Gearin, P.J., M.A. Johnson, and S. Joner. 1991. Harbor porpoise interactions with the Makah Chinook Salmon Set-Net Fishery, 1988-89. In H. Kajimura (Ed.). Harbor porpoise interactions with Makah Salmon set net fishery in coastal Washington waters, 1988-89. National Marine Mammal Laboratory Processed Report. National Marine Mammal Laboratory, 7600 Sand Point Way NE, Seattle, WA 98115-0070. 
Green, G.A., J.J. Brueggeman, C.E. Bowlby, R.A. Grotefendt, M.L. Bonnell, and K.T. Balcomb, III. 1992. Cetacean distribution and abundance off Oregon and Washington, 1989-1990. In J.J. Brueggeman (Ed.). Final report prepared by Ebasco Environmental and Ecological Consulting, Inc. For Minerals Management Service, Pacific OCS P.egion. OCS Study MMS 91-0093. 100 pp.

Hart, J.L. 1973. Pacific fishes of Canada. Fish. Res. Bd. Can. Bull. 180. 740pp.

Heimlich-Boran, J.R. 1987. Habitat use patterns and behavioral ecology of killer whales (Orcinus orca) in the Pacific Northwest. M.S. Thesis, Moss Landing Marine Laboratories. 59pp.

Hixon, R.F. 1983. Loligo opalescens. In P.R. Boyle (Ed.). Cephalopod life cycles, Vol. 1. Academic Press Inc., Ltd. London.

Hui, C. 1979. Undersea topography and distribution of dolphins of the genus Delphimus in the Southern California Bight. J. Mamm. 69(3):521-527.

Jones, R.E. 1981. Food habits of smaller marine mammals from northern California. Pro. Calif. Acad. Sci. 42(16):409-433.

Kozloff, E.N. 1973. Seashore life of Puget Sound, the Strait of Georgia, and the San Juan Archipelago. Univ. of WA press. Seattle. 282pp.

Kraus, S.D., J.R. Gilbert, and J.H. Prescott. 1983. A comparison of aerial, shipboard, and land-based survey methodology for the harbor porpoise (Phocoena phocoena). Fish. Bull. 81:910-913.

Kraus, S.D. and J.H. Prescott. 1984. Seasonal movements of harbor porpoise (Phocoena phocoena) in the Gulf of Maine. Rept. To NMFS, NOAA, Woods Hole, MA. 10pp.

Laake, J.L., S.T. Buckland, D.R. Anderson, and K.P. Burnham. 1993. DISTANCE User's Guide. Colorado Cooperative Fish and Wildlife Research Unit, Colorado State University, Fort Collins, CO 80523. 84pp.

LaBarr, M.S., and D.G. Ainley. 1985. Depth distribution of harbor porpoise off central California: a report of cruises in April and May-June 1985. NMFS Contract No. 41 USC 252. $23 \mathrm{pp}$.

Lemberg, N.A. 1978. Hydroacoustic assessment of Puget Sound herring, 1972-1978. Washington Dept. Of Fisheries, Tech. Rep. 41. 43pp. 
Marine Mammal Commission. 1990. Annual report of the Marine Mammal Commission, calendar year 1990. Report to Congress. 270pp.

Marine Mammal Commission. 1993. Annual report of the Marine Mammal Commission, calendar year 1992. Report to Congress. 226pp.

Miller, R.G., Jr. 1966. Simultaneous statistical inference. McGraw-Hill, New York. 272pp.

Miller, E.J. 1989. Distribution and behavior of Dall's porpoise (Phocoenoides dalli) in Puget Sound, Washington. M.S. thesis, University of Washington. 97pp.

Morejohn, G.V., J.T. Harvey, and L.T. Krasnow. 1978. The importance of Loligo opalescens in the food web of marine vertebrates in Monterey Bay, California. In Recksiek, C.W. and H.W. Frey (Eds.). Biological, oceanographic, and acoustic aspects of the market squid Loligo opalescens Berry, CA. Fish. Bull. 169:67-98.

Neave, D.J. and B.S. Wright. 1968. Seasonal migrations of the harbor porpoise (Phocoena phocoena) and other cetacea in the Bay of Fundy. J. Mamm. 49(2):259264.

NOAA 1991. High and low water predictions: West coast of North and South America including the Hawaiian Island. U.S. Dept. Commer. NOAA. 238pp.

Palka, D.L. 1993. Estimating density of animals when assumptions of line-transect surveys are violated. PhD. Dissertation, University of California, San Diego. 169pp.

Pike, G.C. and I.B. MacAskie. 1969. Marine mammals of British Columbia. Fish. Res. Bd. Can. Bull. 171:1-54.

Polacheck, T. and T.D. Smith. 1989. A proposed methodology for field testing line transect theory for shipboard surveys of cetaceans. Rep. Int. Whal. Commn. 39:341345.

Polacheck, T. and L. Thorpe. 1990. The swimming direction of harbor porpoise in relationship to a survey vessel. Rep. Int. Whal. Commn. 40:463-470.

Prescott, J.H. and P.M. Fiorelli. 1980. Review of the harbor porpoise (Phocoena phocoena) in the U.S. Northwest Atlantic. National Tech. Info. Ser. U.S. Dept. of Comm. pb-80-176928. 64pp.

Rae, B.B. 1965. The food of the common porpoise (Phocoena phocoena). J. Zool. 146:114-122. 
Read, A.J. and D.E. Gaskin. 1985. Radio-tracking the movements and activities of harbor porpoises, Phocoena phocoena $(\mathrm{L}$.), in the Bay of Fundy using radio telemetry. Can. J. Zool. 53(10):1466-1471.

Recchia, C.A. and A.J. Read. 1989. Stomach contents of harbour porpoises, Phocoena phocoena (L.), from the Bay of Fundy. Can. J. Zool. 67:2140-2146.

Rosel, P.E., A.E. Dizon, and M.G. Haygood. In press. Variability of the mitochondrial control region in populations of the harbour porpoise, Phocoena phocoena, on interoceanic and regional scales. Can. J. Fish. Aquat. Sci. 30pp.

Scheffer, V.S. and J. Slipp. 1948. The whales and dolphins of Washington State with a key to the cetaceans of the west coast of North America. Am. Midl. Nat. 39:257337.

Sergeant, D.E. 1969. Feeding rates of cetacea. FiskDir. Skr. Ser. HavUnders. 15:246258.

Sekiguchi, K. 1987. Occurrence and behavior of harbor porpoise (Phocoena phocoena) at Pajaro Dunes, Monterey, California. M.S. thesis, Moss Landing Marine Laboratories. 49pp.

Smith, T.D. 1982. Testing methods of estimating range and bearing to cetaceans aboard the R/V P.S. Jordan. NOAA Tech. Mem. NMFS, NOAA, La Jolla, CA 92038. $30 \mathrm{pp}$.

Smith, G.J.D., and D.E. Gaskin. 1974. The diet of the harbor porpoises (Phocoena phocoena) in coastal waters of eastern Canada, with special reference to the Bay of Fundy. Can. J. Zool. 50:1611-1616.

Smith, G.J.D., and D.E. Gaskin. 1983. An environmental index for habitat utilization by female harbour porpoises with calves near Deer Island, Bay of Fundy. Ophelia. 22:115.

Sumich, J.L. 1994. Oxygen extraction in free-swimming gray whale calves. Mar. Mamm. Science. 10(2):226-230.

Suryan, R.M. 1995. Pupping phenology, disturbance, movements, and dive patterns of the harbor seal (Phoca vitulina richardsi) off the northern San Juan Islands of Washington. M.S. Thesis, Moss Landing Marine Laboratories. 75pp. 
Taylor, B.L. and P.K. Dawson. 1984. Seasonal changes in density and behavior of harbor porpoise (Phocoena phocoena) affecting censusing methodology in Glacier Bay National Park, Alaska. Rep. Int. Whal. Comm. 34:479-483.

Watkins, W.A. 1986. Whale reactions to human activities in Cape Cod waters. Mar. Mamm. Sci. 2(4):251-262.

Watson, A.P. 1976. The diurnal behaviour of the harbour porpoise (Phocoena phocoena L.) in the coastal waters of the western Bay of Fundy. M.S. Thesis, Univ. of Guelph, Ontario, Canada. 94pp.

Watson, A.P. 1981. Sea guide to whales of the world. E.P. Dutton, New York. 302pp.

Watson, A.P. and D.E. Gaskin. 1983. Observations on the ventilation cycle of the harbor porpoise Phocoena phocoena (L.) in coastal waters of the Bay of Fundy. Can. J. Zool. 61(1):126-132.

Watts, P. and D.E. Gaskin. 1985. Habitat index analysis of the harbor porpoise (Phocoena phocoena) in the southern coastal waters of the Bay of Fundy. Can. J. Zool. 61(1): 126-132.

Würsig, B. and M. Würsig. 1977. The photographic determination of group size, composition, and stability of coastal porpoises (Tursiops truncatus). Science 198:755-6.

Yurick, D.B. 1977. Populations, subpopulations, and zoogeography of the harbor porpoise Phocoena phocoena L. M.S. Thesis, Univ. of Guelph, Ontario, Canada. 148pp.

Yurick, D.B. and D.E. Gaskin. 1987. Morphometric and meristic comparisons of skulls of harbour porpoise Phocoena phocoena (L.) from the North Atlantic and North Pacific. Ophelia 27(1):53-75.

Zar, J.H. 1984. Biostatistical analysis (second edition). Prentice-Hall, Inc. Englewood Cliffs, N.J. 718pp. 


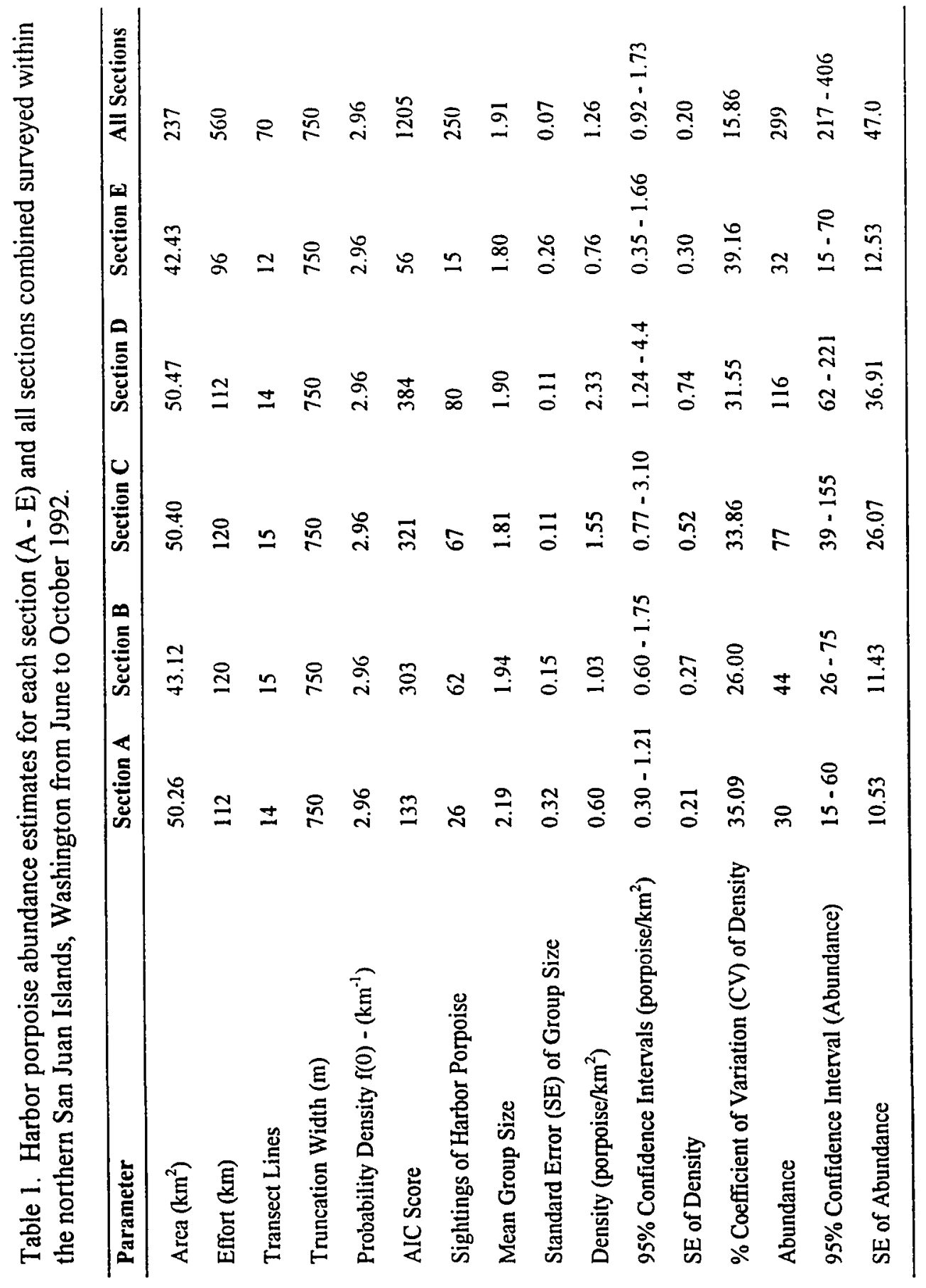




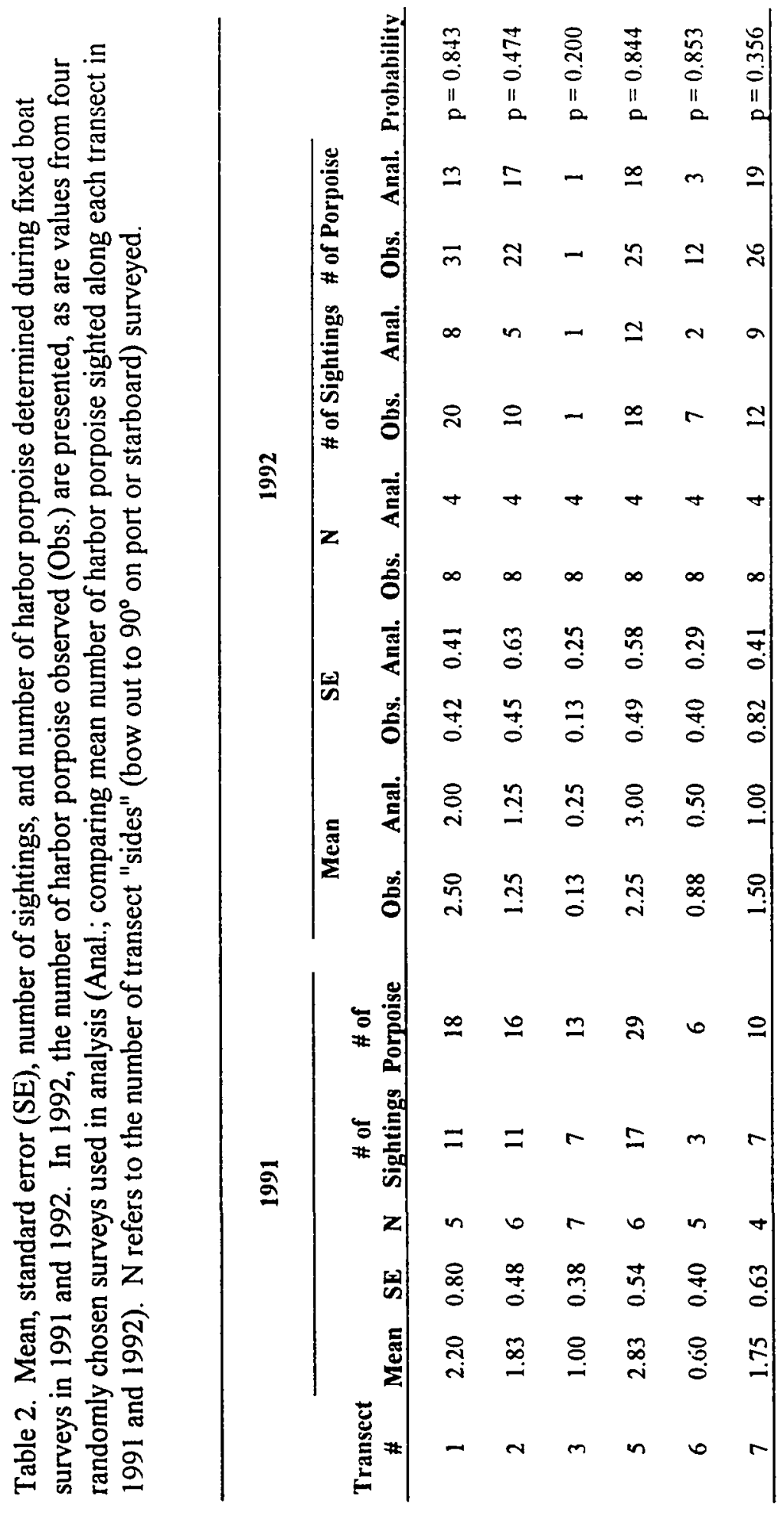




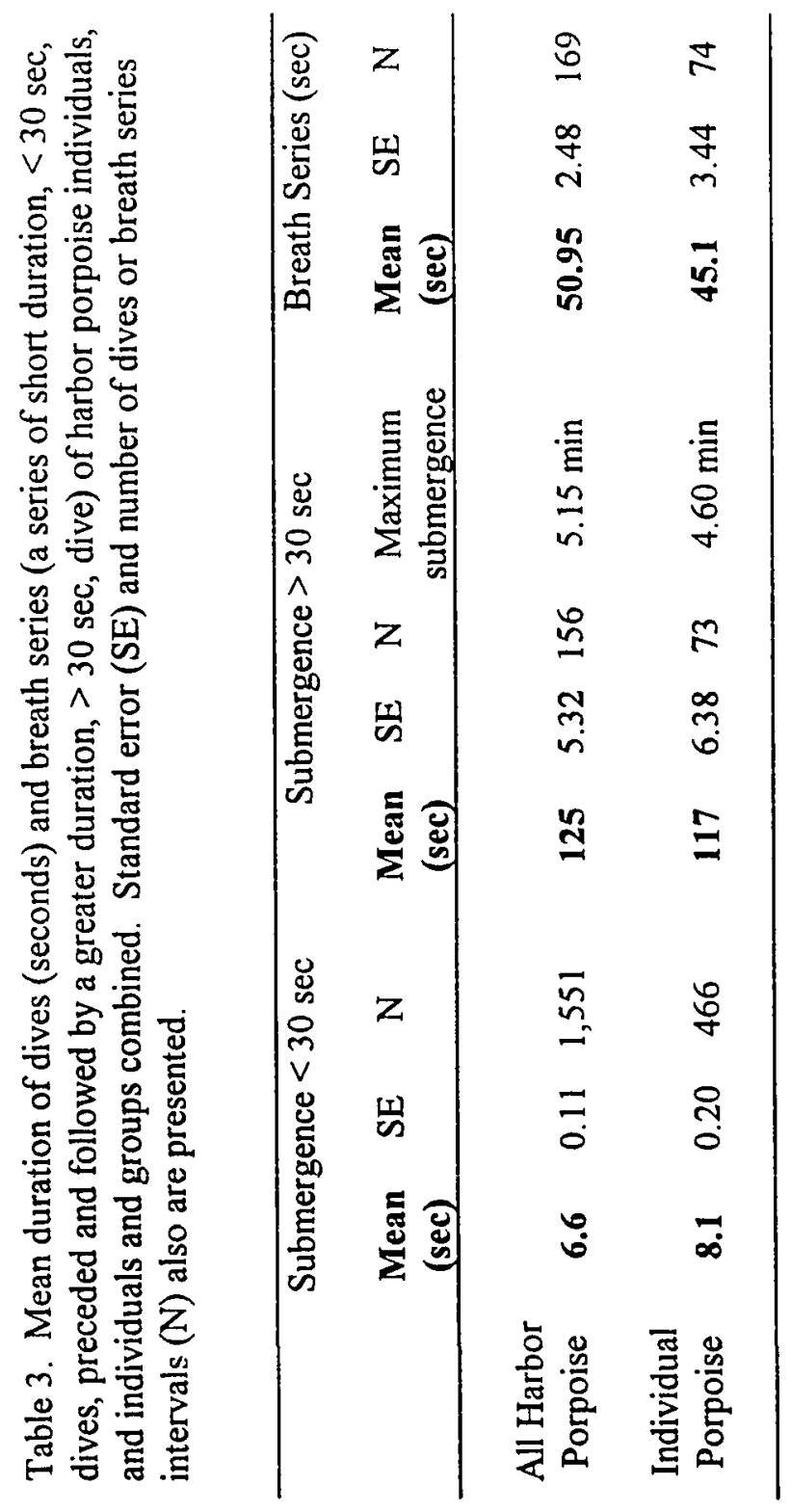




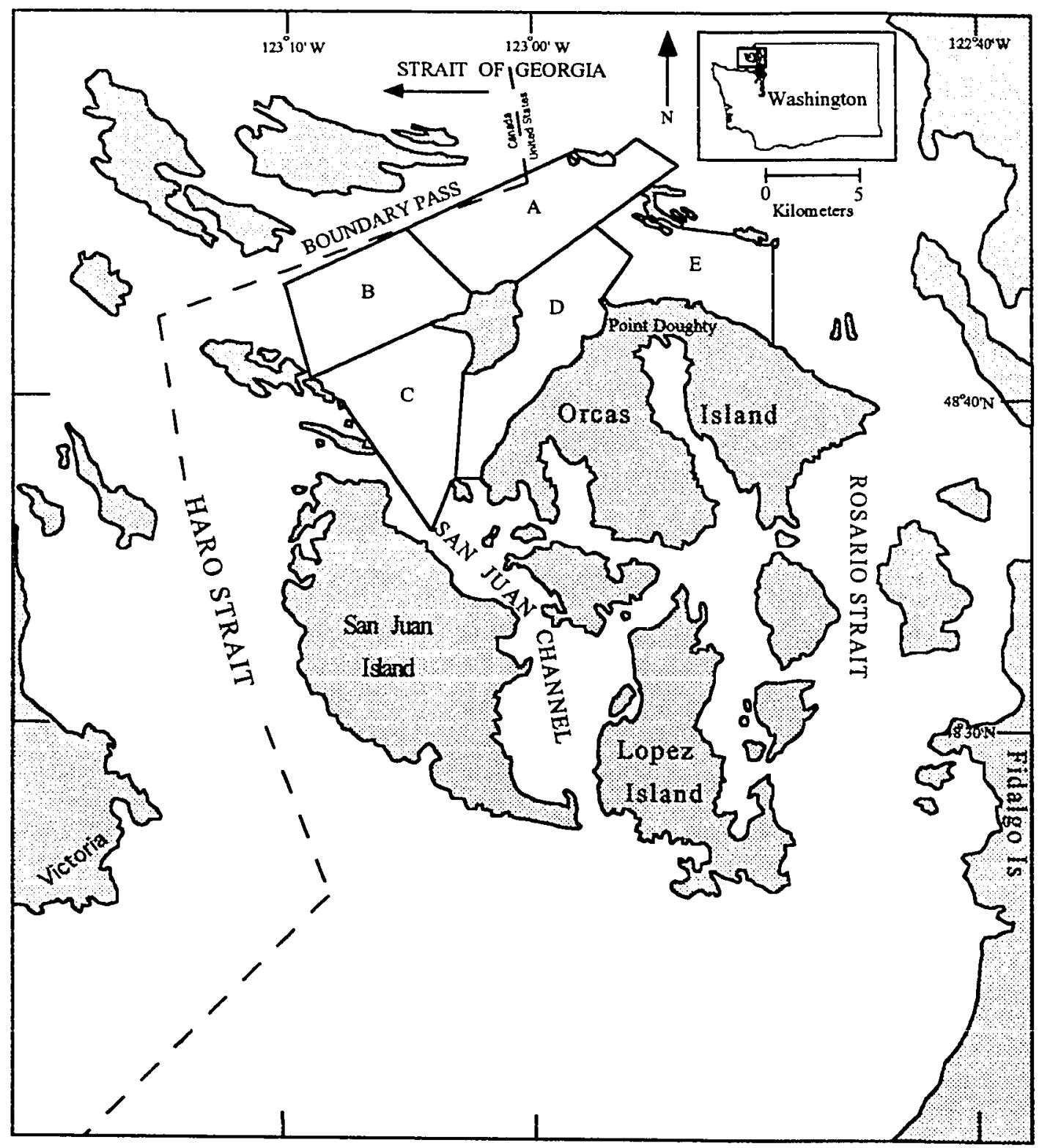

Figure 1. Study area stratified into five approximately equal sections (lettered A, B, C, D, E) used during random boat surveys from June to October 1992. Point Doughty, Orcas Island, Washington was the site of shore-based surveys in 1991 and 1992. 


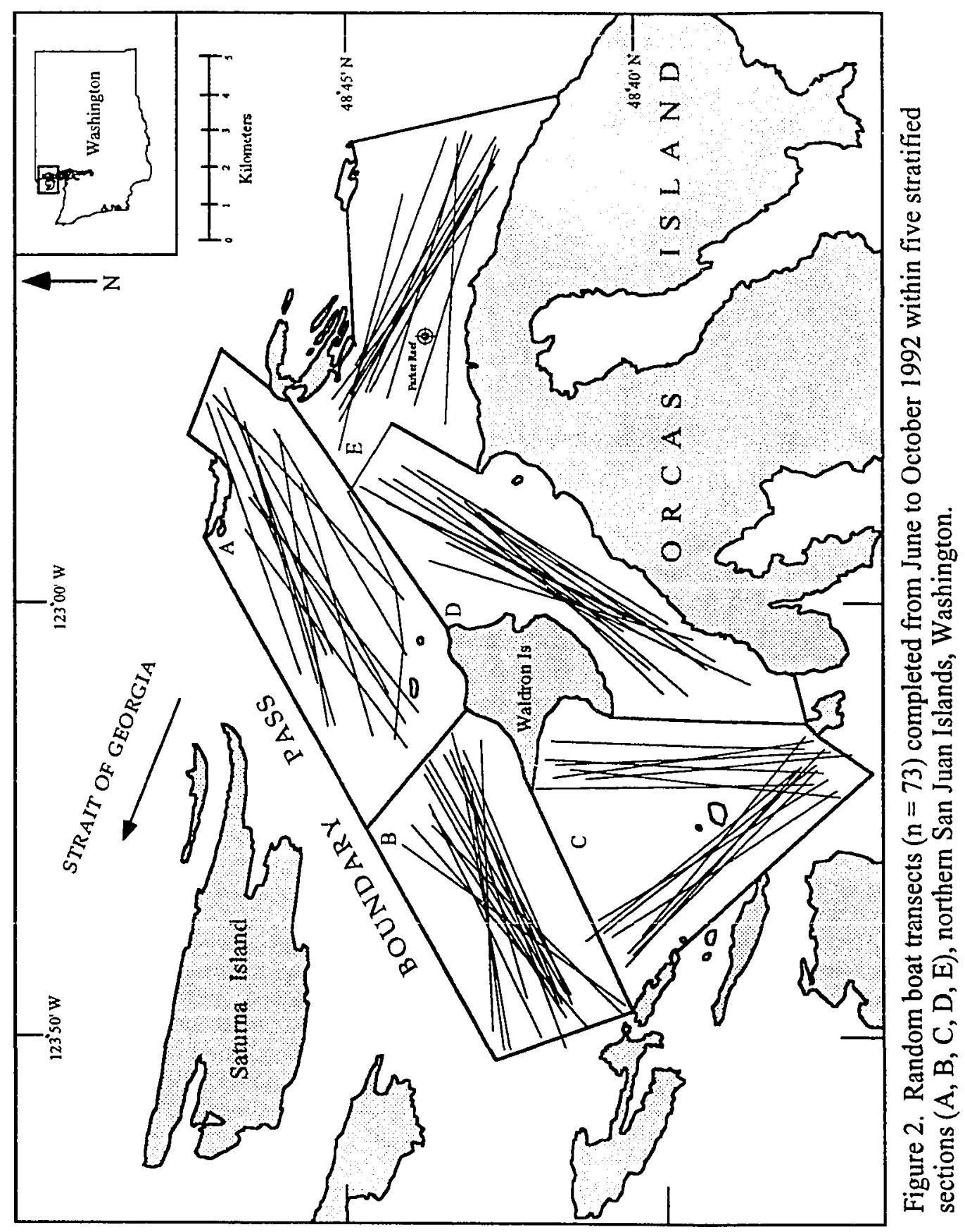




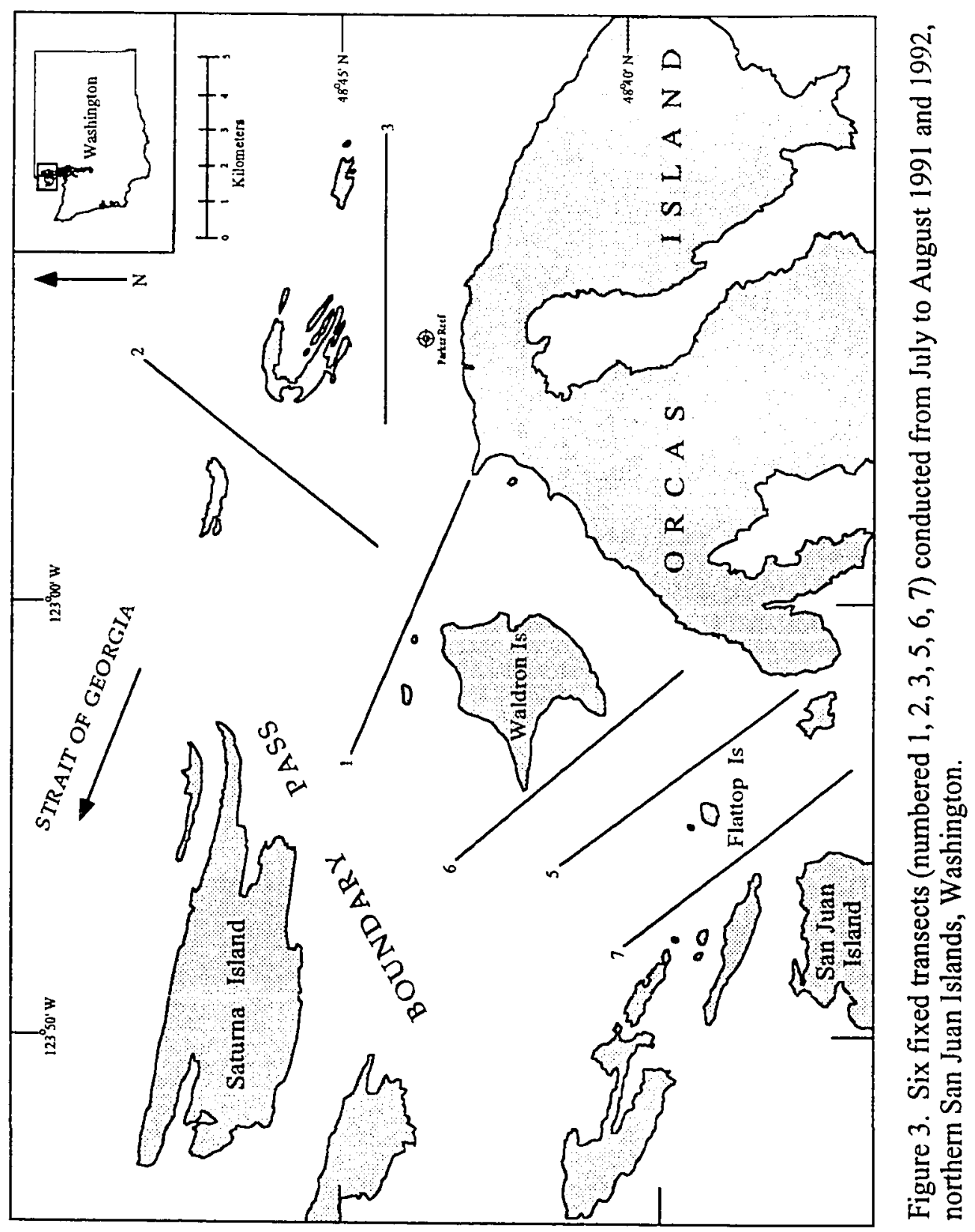




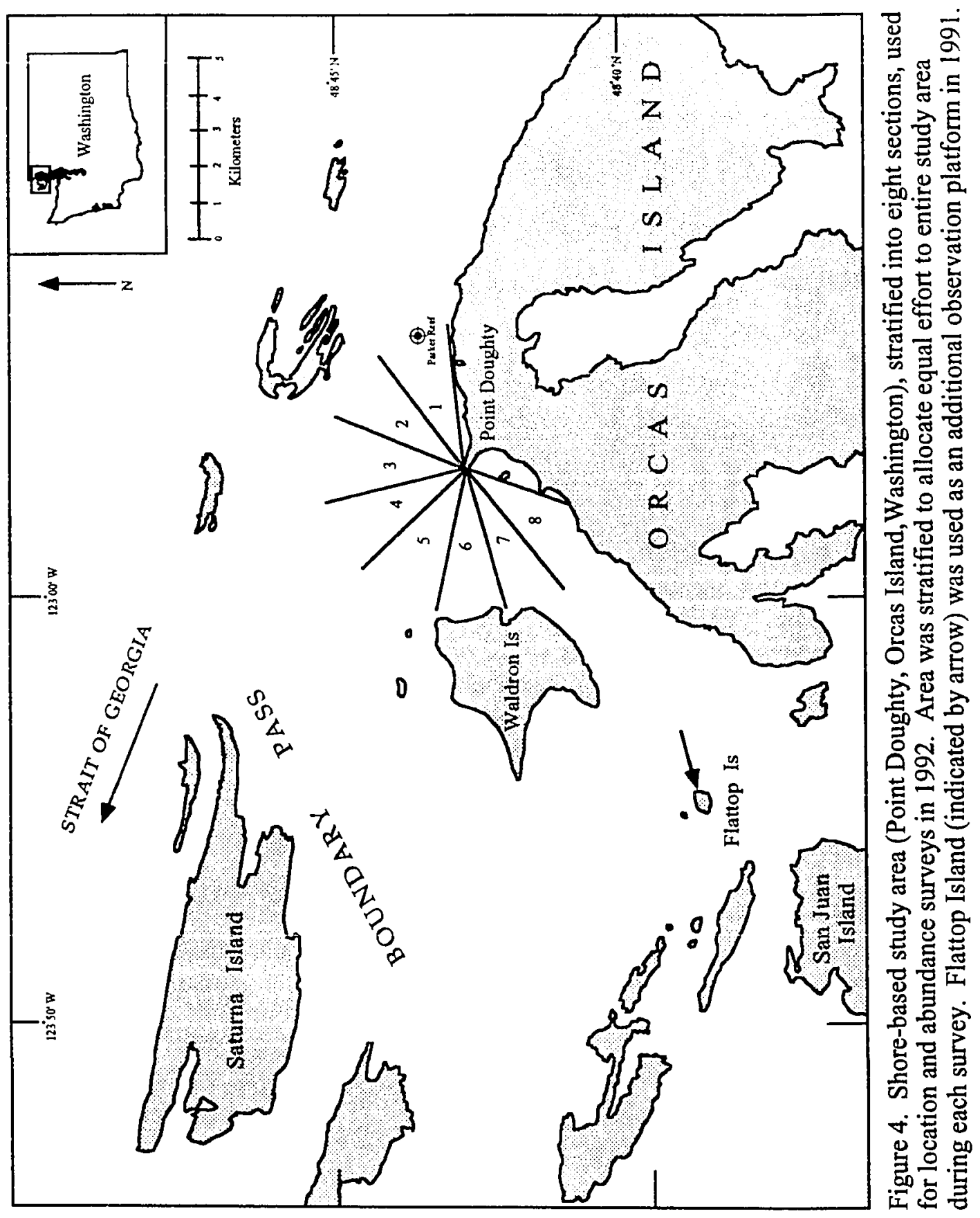




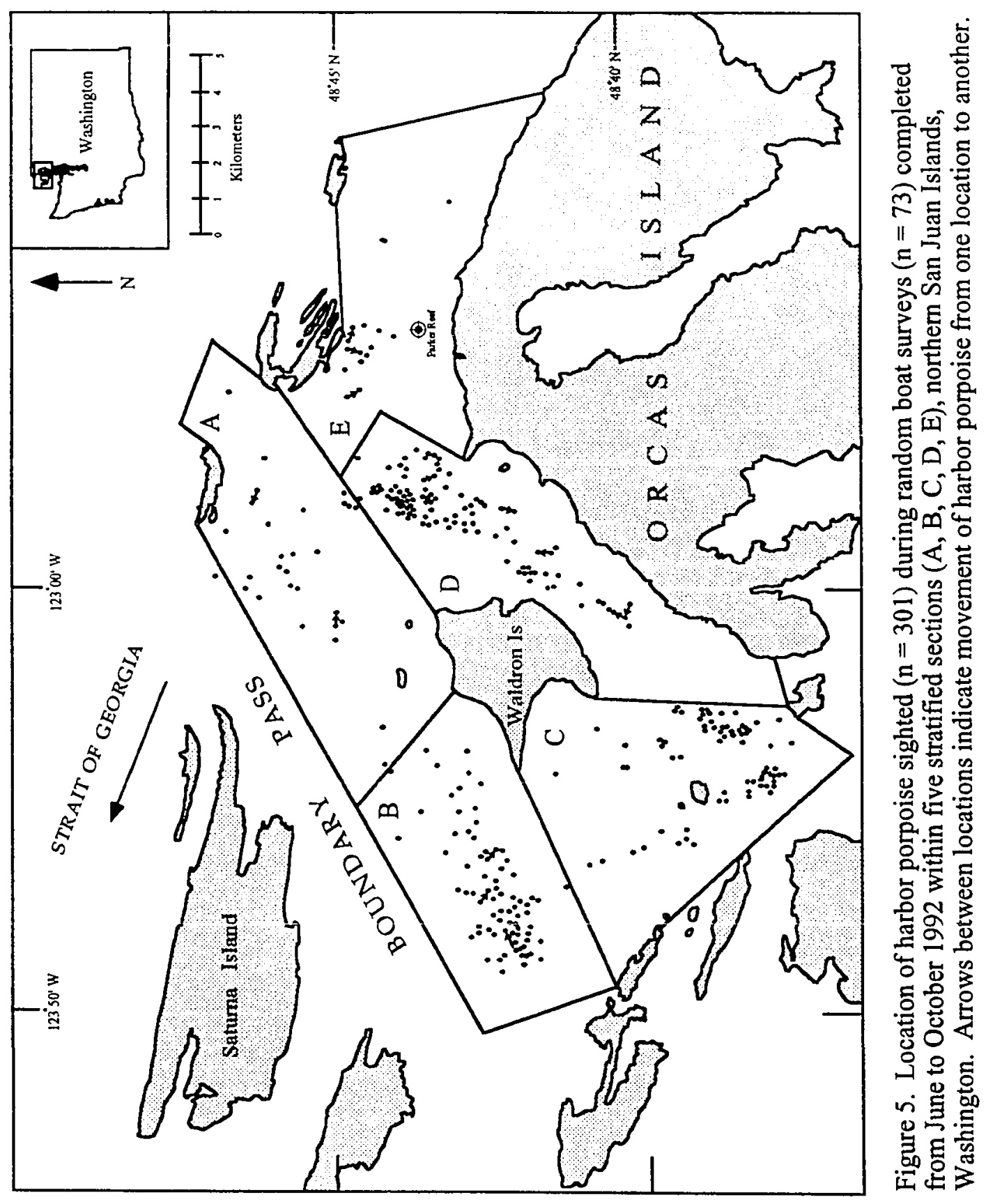




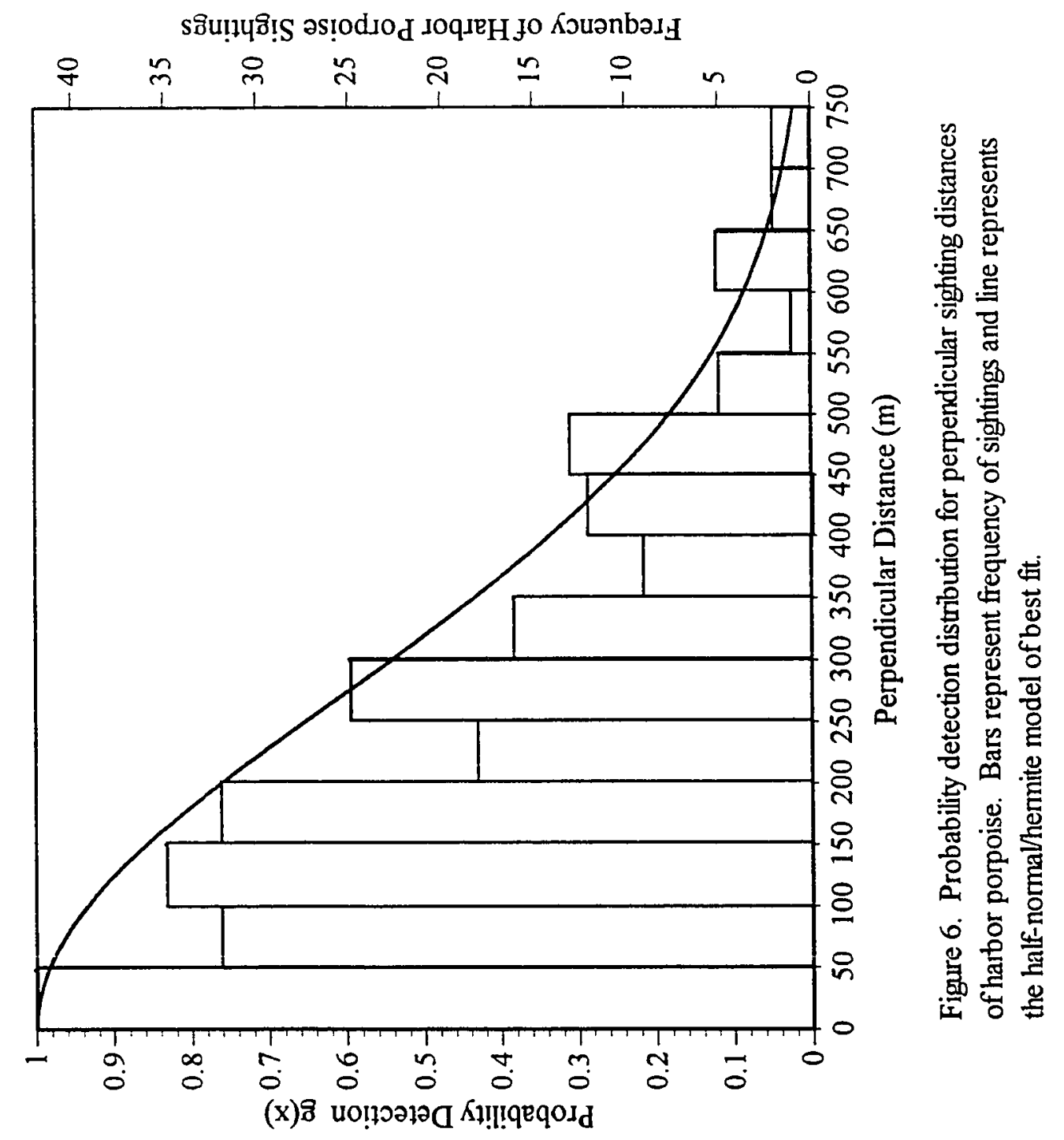



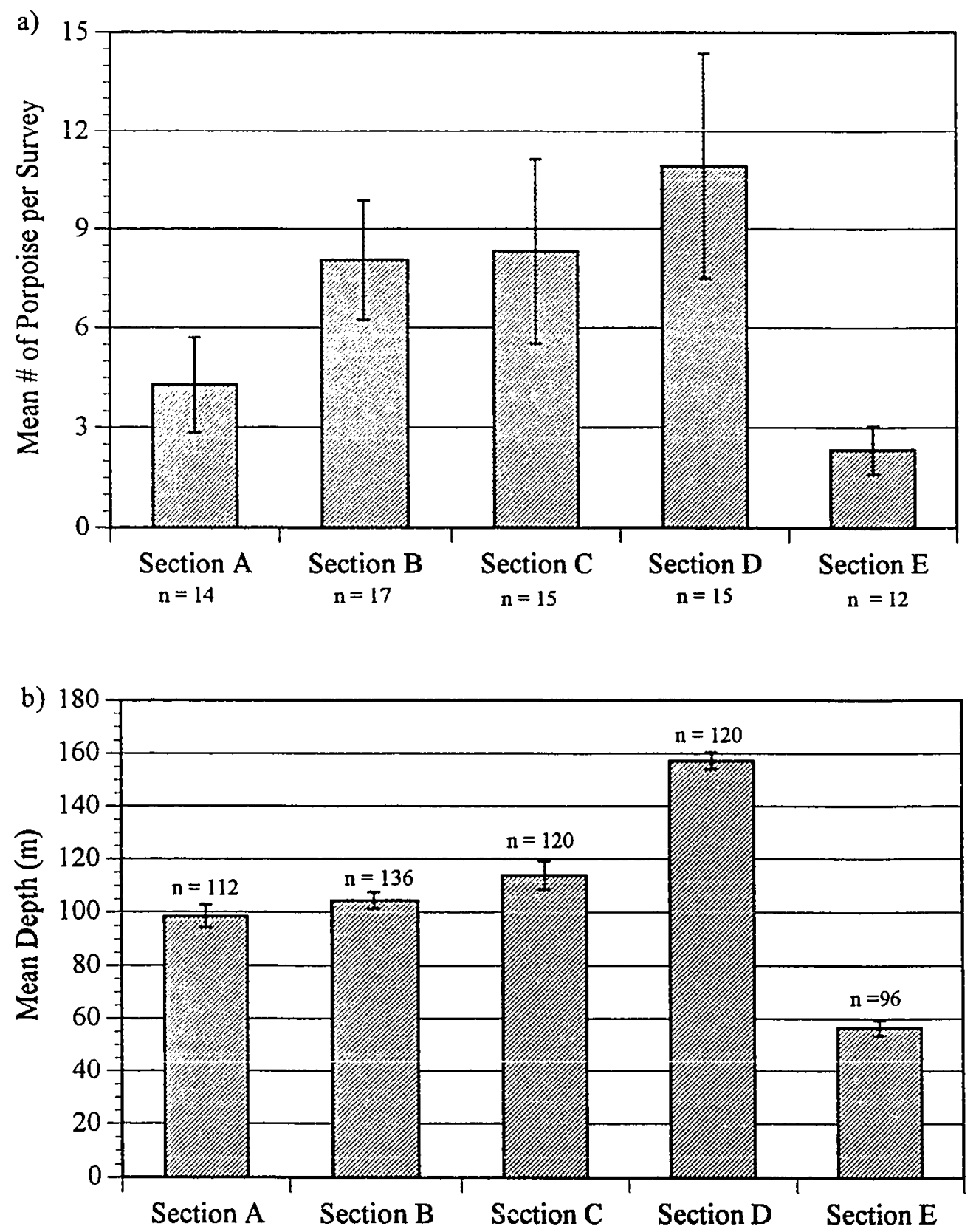

Figure 7. Mean number of harbor porpoise (a) and mean water depth (b) of each section (A - E) determined during random boat surveys (June to October 1992). Vertical lines represent standard error and " $n$ " represents number of transects completed in each section (a) and random depth locations plotted within each section $(b$; total $=584)$. 

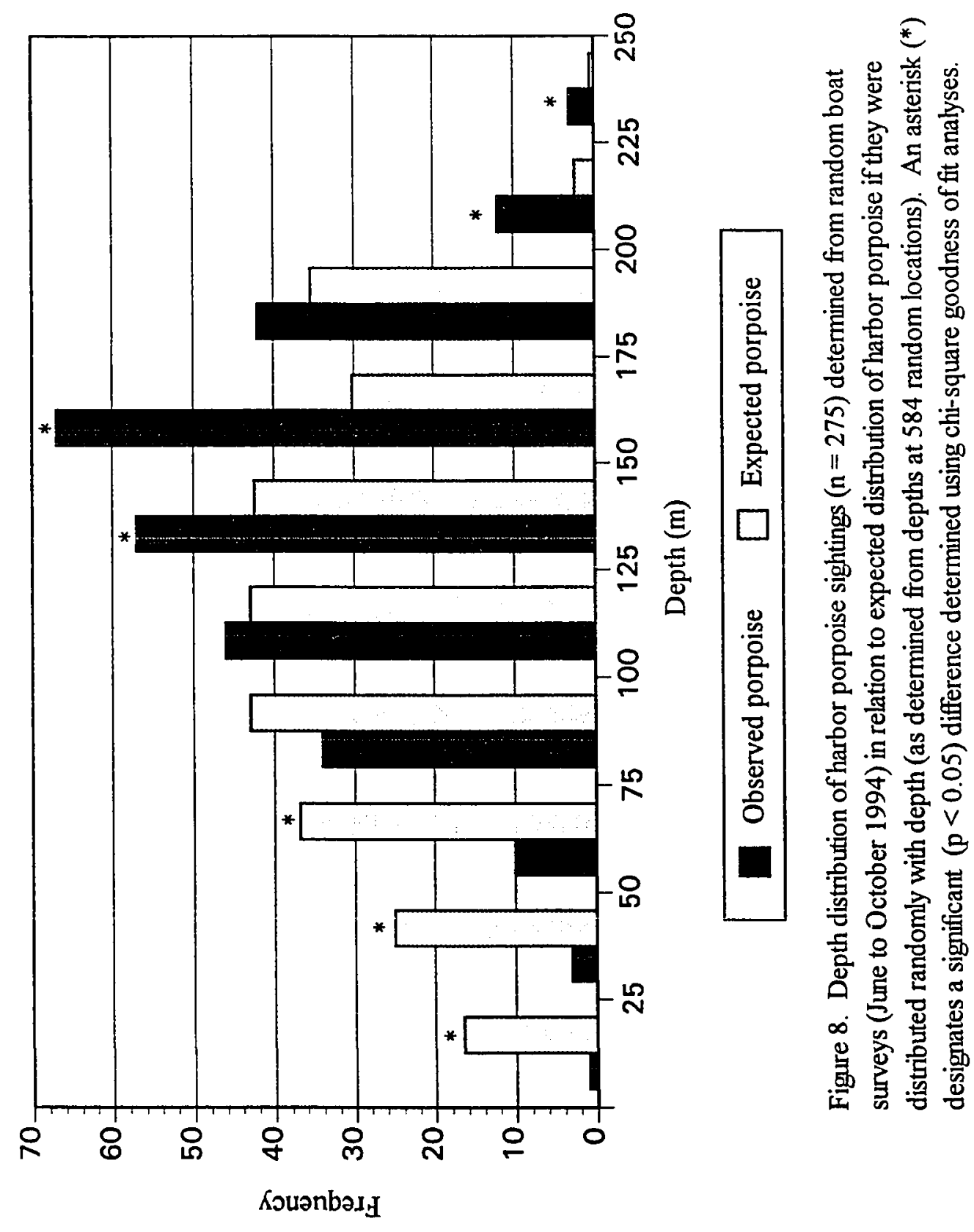


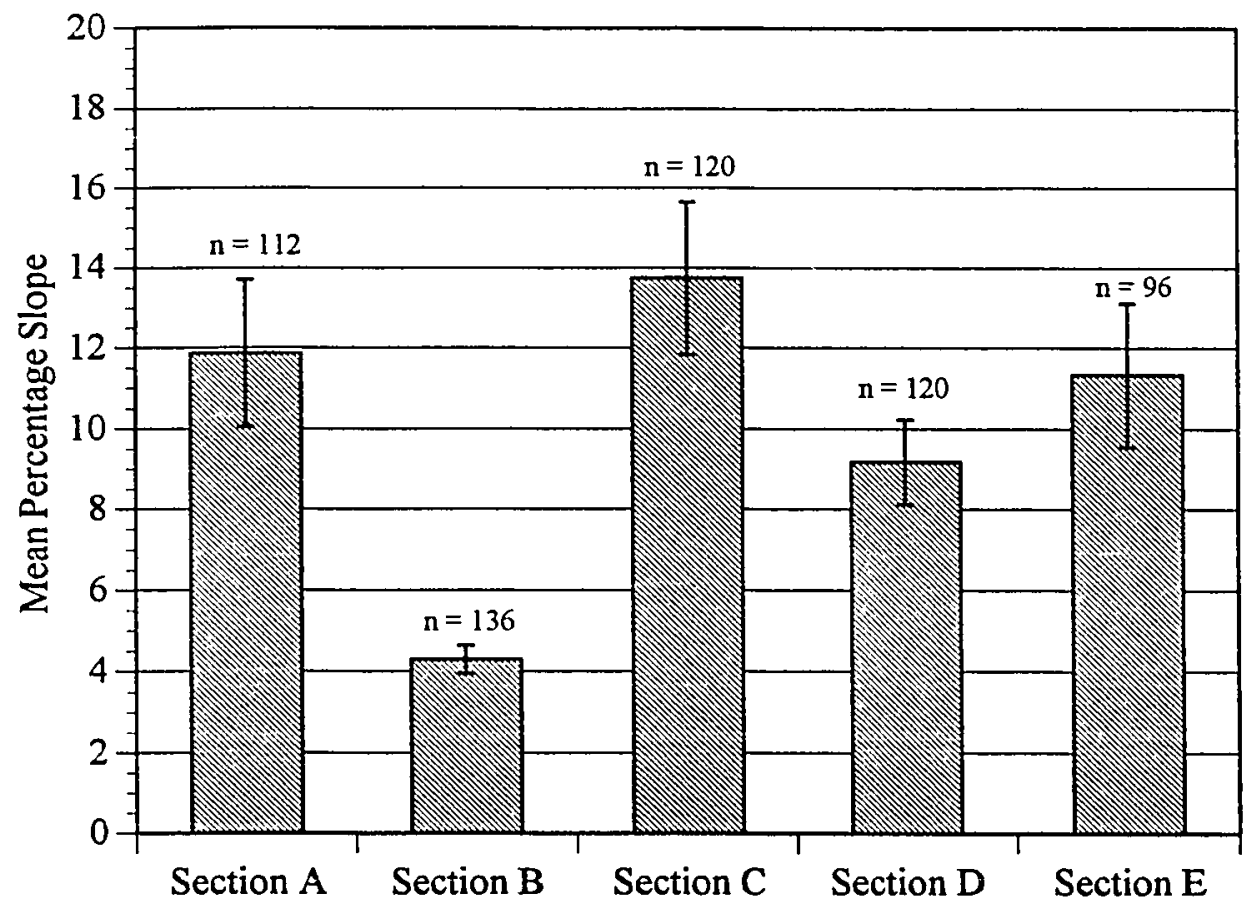

Figure 9. Mean percentage slope of seafloor for each section (A - E) determined from random boat surveys. Vertical lines represent standard error and " $n$ " represents the number of random slope locations plotted within each section (total $=584$ ). 

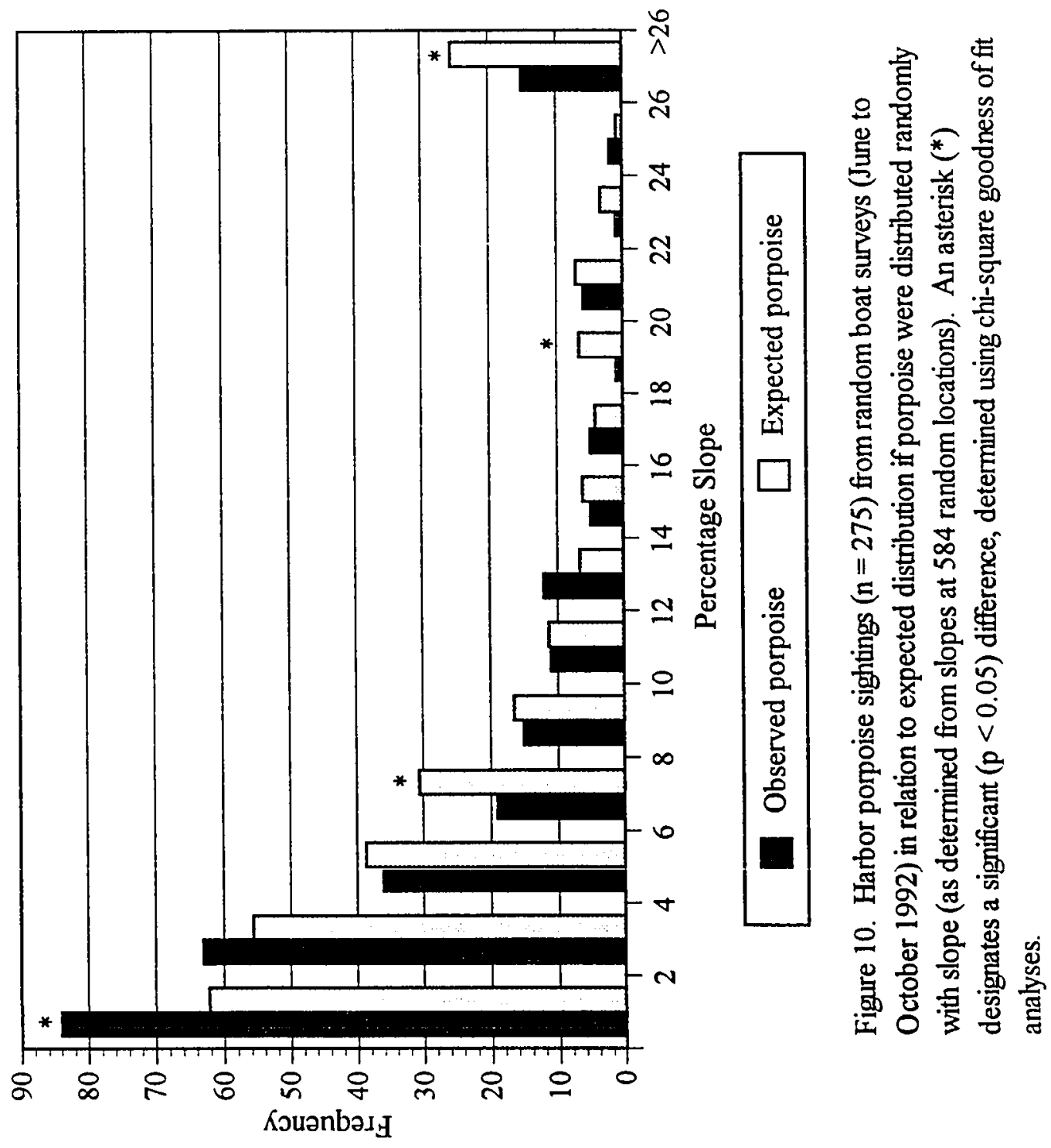


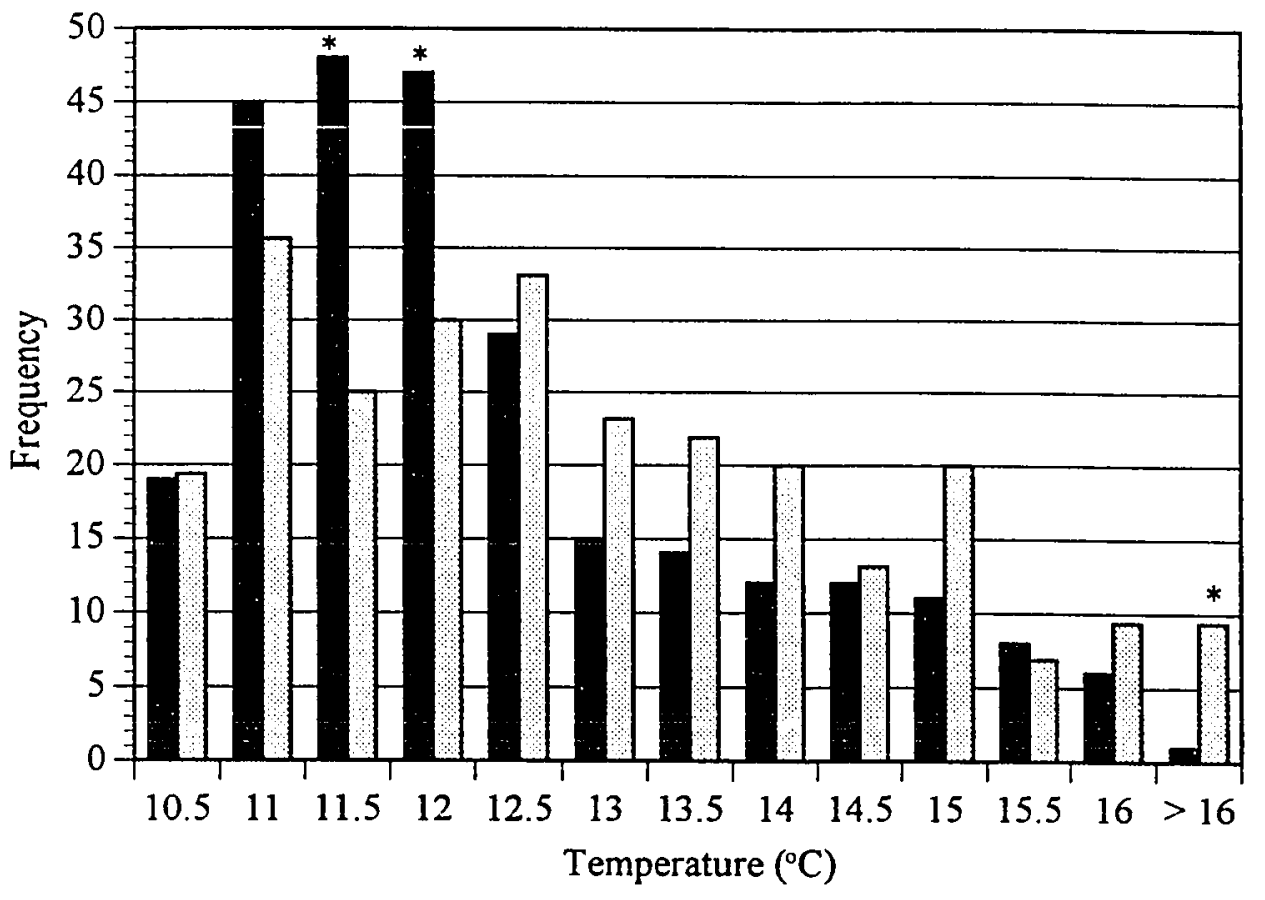

Frequency of Porpoise Sightings

Expected Frequencies (Boat Survey Temperatures)

Figure 11. Sea surface temperatures $\left({ }^{\circ} \mathrm{C}\right)$ recorded at harbor porpoise sightings $(n=267)$ in relation to expected distribution of harbor porpoise if they were distributed randomly with temperature (as determined from temperatures recorded at 427 locations along 73 random transect lines). An asterisk $\left(^{*}\right)$ designates a significant $(p<0.05)$ difference, determined using chi-square goodness of fit analyses. 


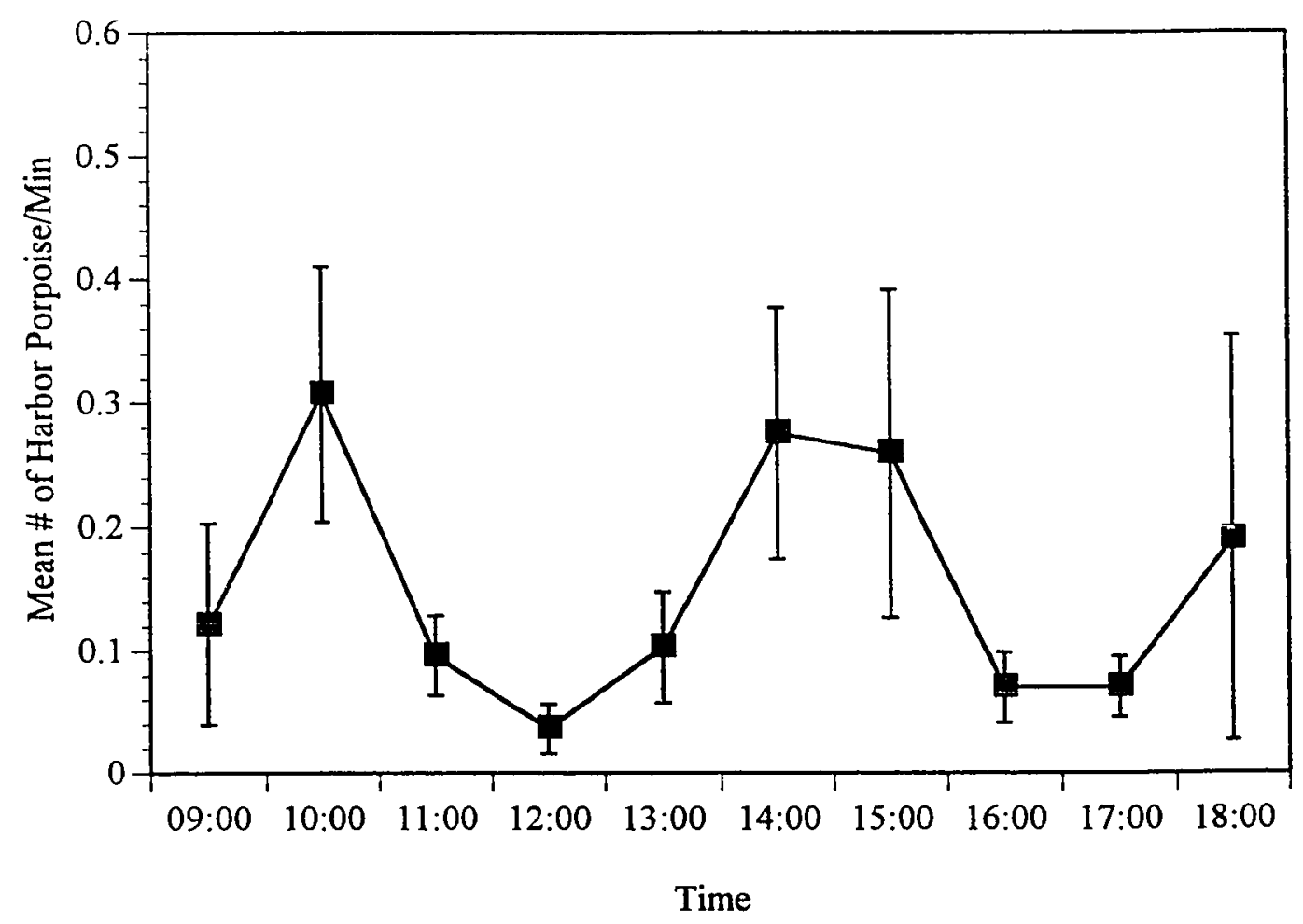

Figure 12. Mean number of harbor porpoise observed per minute during random boat surveys (June to October 1992) for all sections (A - E) combined. Vertical lines represent standard error. 


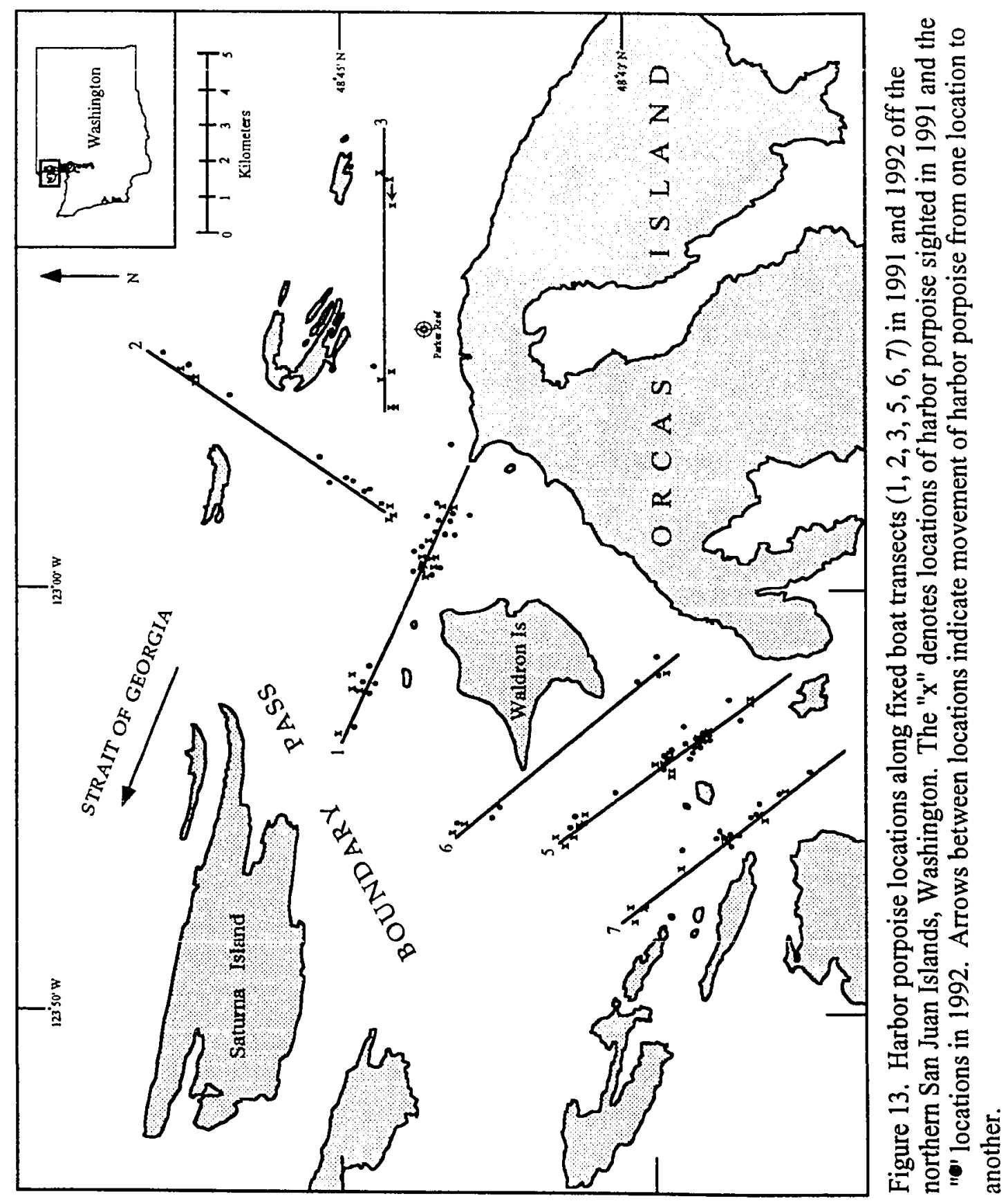




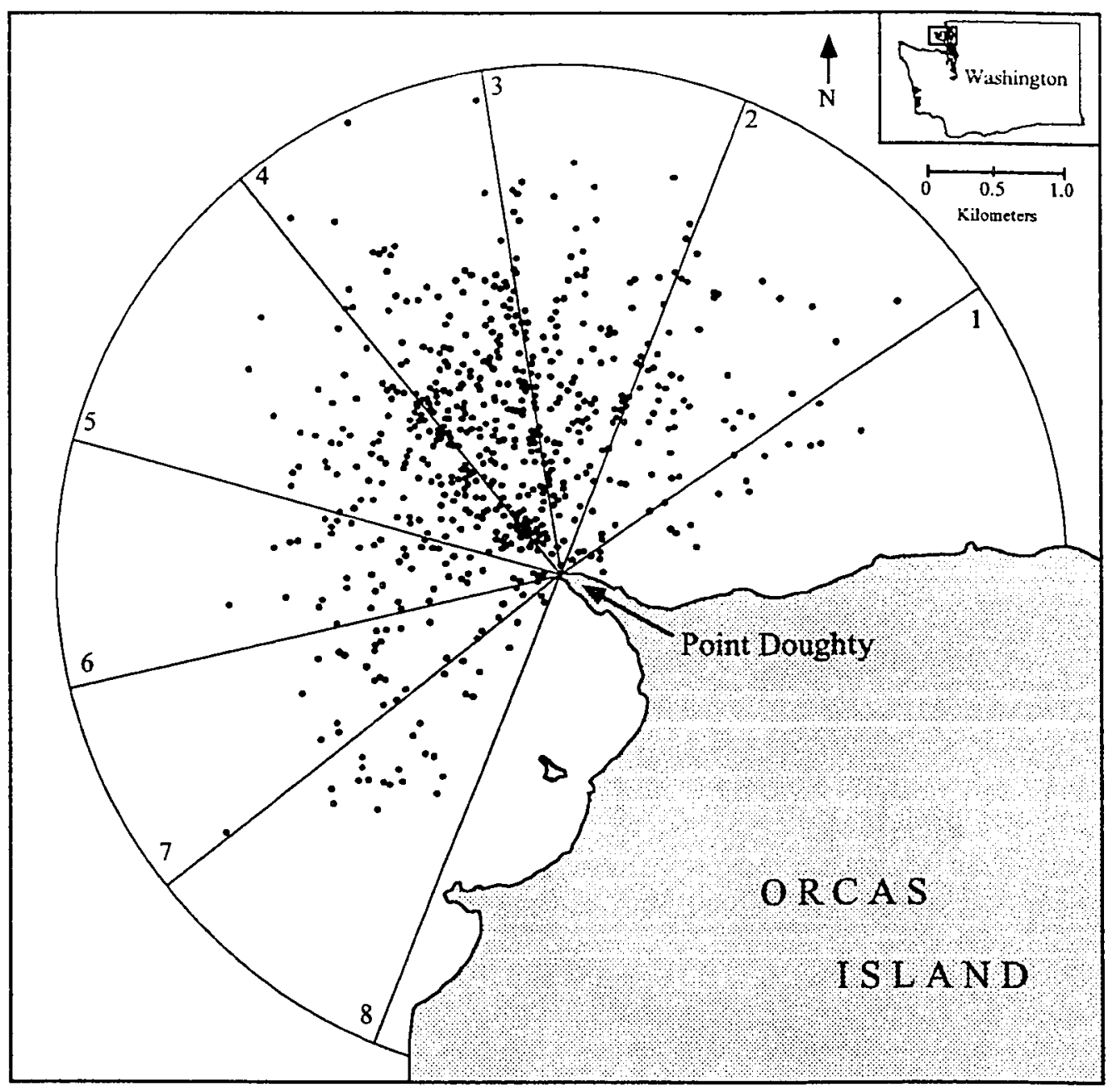

Figure 14. Location of harbor porpoise sighted $(n=617)$ during shore-based location surveys (Point Doughty, Orcas Island, Washington) from June to October 1992. Due to errors in some distance calculations, 17 sightings were not plotted. 


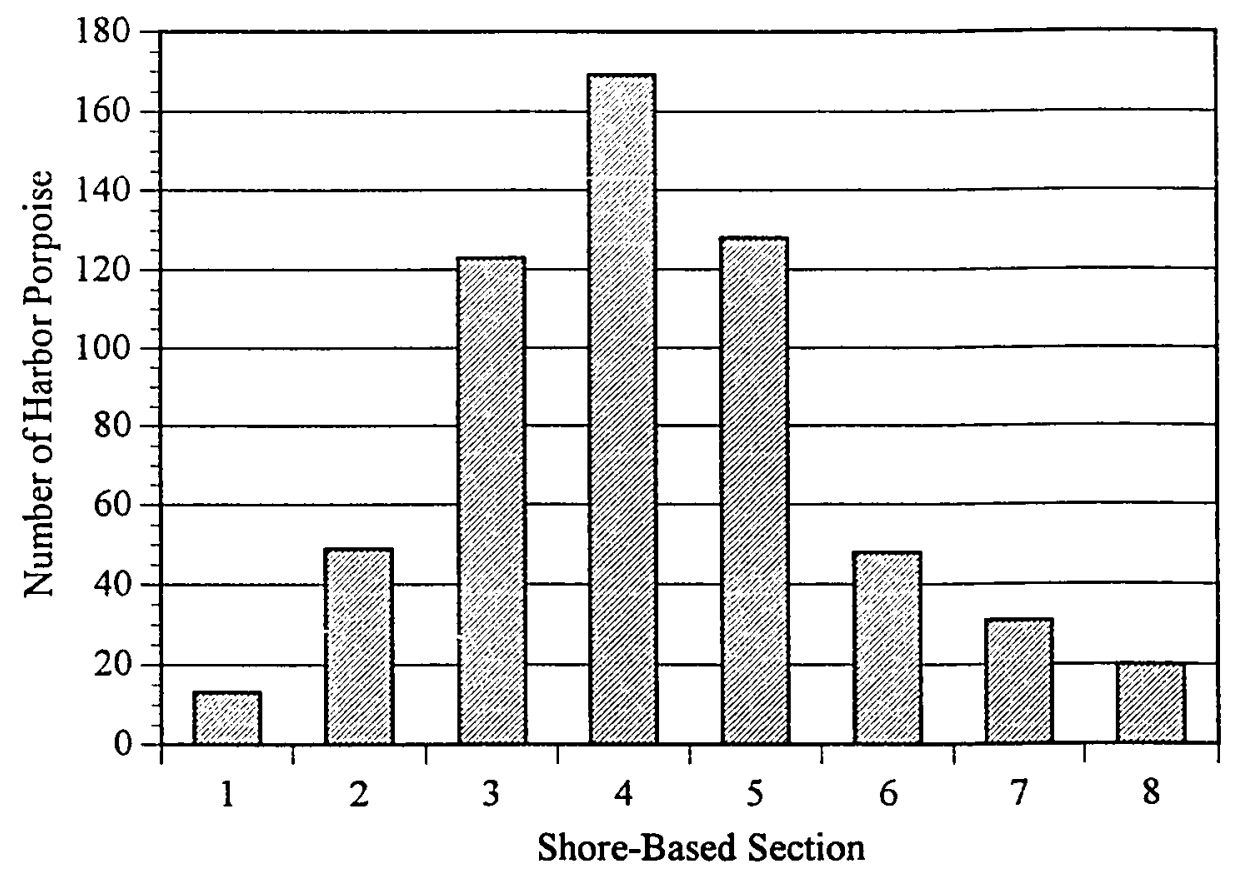

Figure 15. Number of harbor porpoise observed per section $(1-8)$ from Point Doughty, Orcas Island, Washington. Only surveys when all eight sections were completed $(n=63)$ are included (some surveys or sections of surveys were terminated due to adverse weather conditions). 


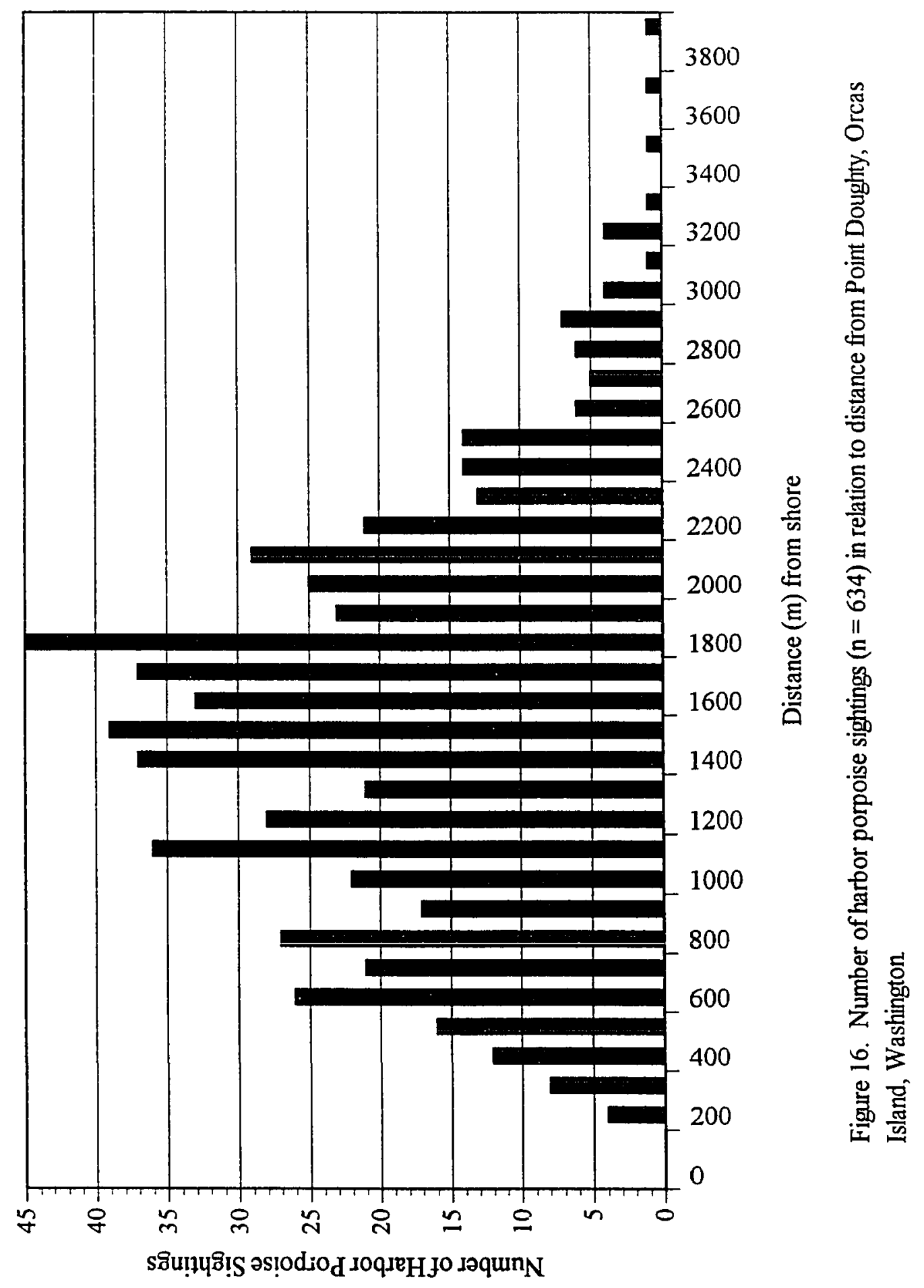




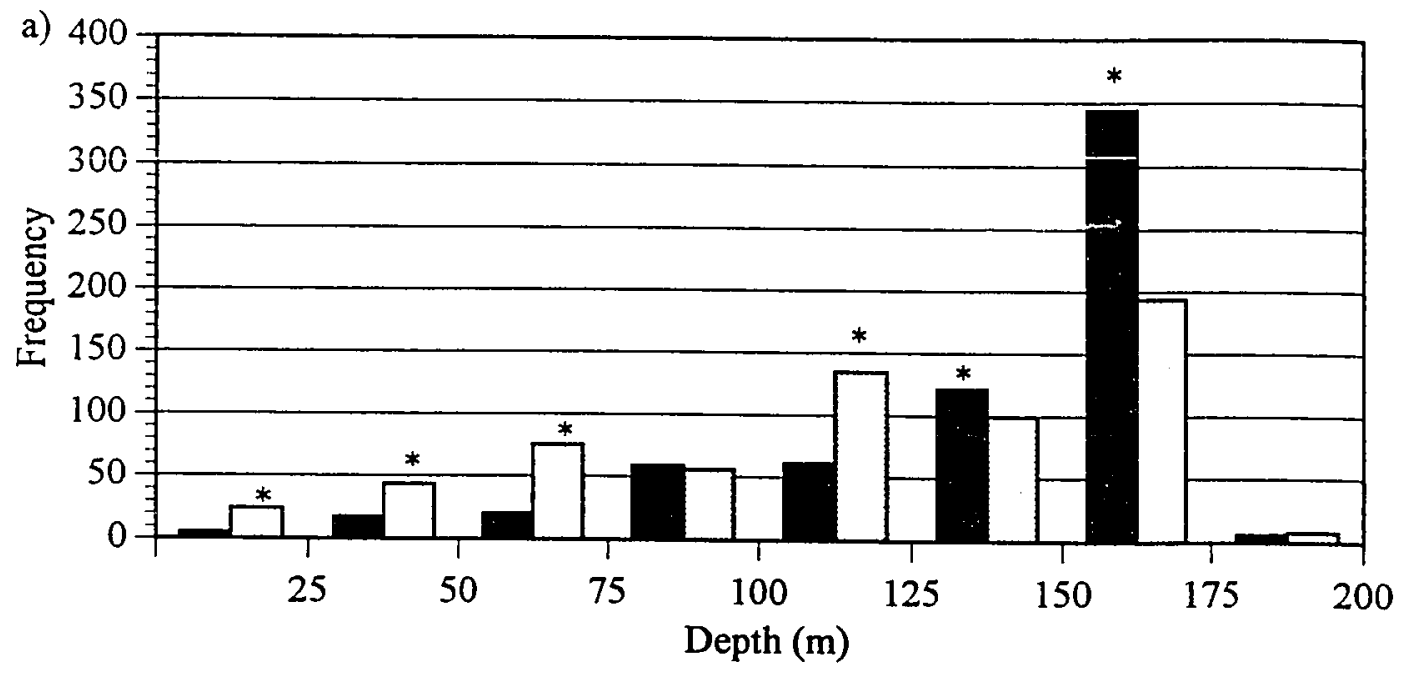

\section{Observed porpoise $\square$ Expected porpoise}

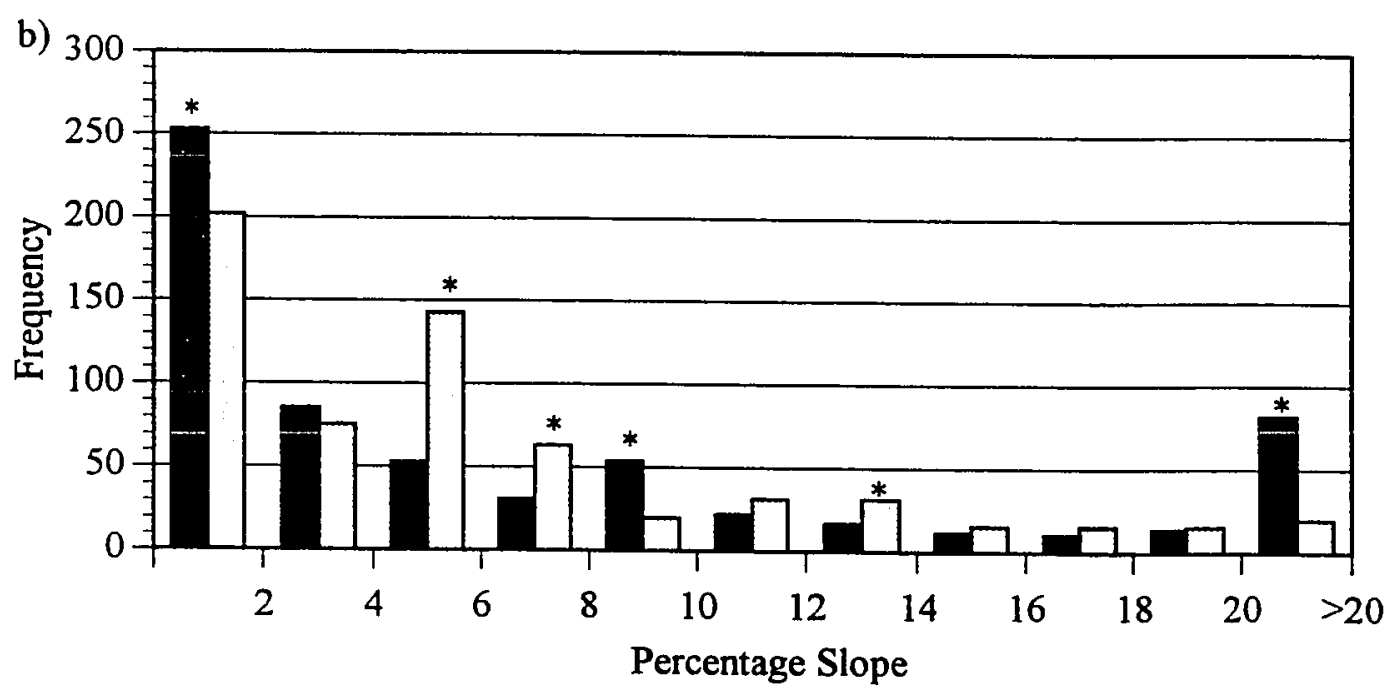

\section{Observed porpoise $\square$ Expected porpoise}

Figure 17. Frequency of harbor porpoise sightings $(n=634)$ in relation to expected distribution if porpoise were distributed randomly with depth (a) and slope (b; as determined from depths and slopes at 160 random locations) off Point Doughty, Orcas Island, Washington. An asterisk $\left(^{*}\right)$ designates a significant $(p<0.05)$ difference, determined using chi-square goodness of fit analyses. 

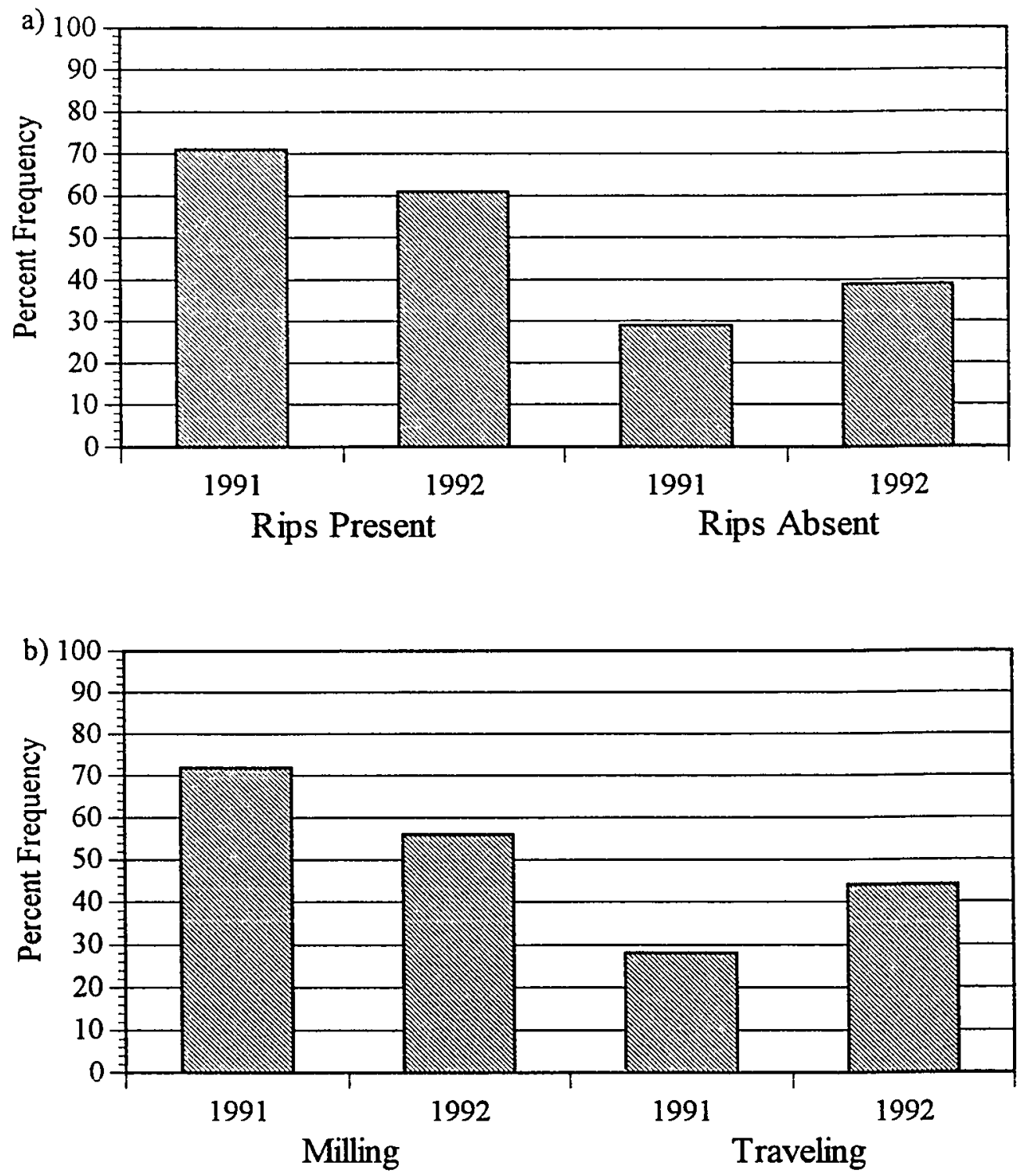

Figure 18. Percent frequency occurrence of harbor porpoise when tide rips were present and absent (a) and when milling and traveling behavior was observed (b) during shore-based location surveys off Point Doughty, Orcas Island, Washington in 1991 and 1992. 


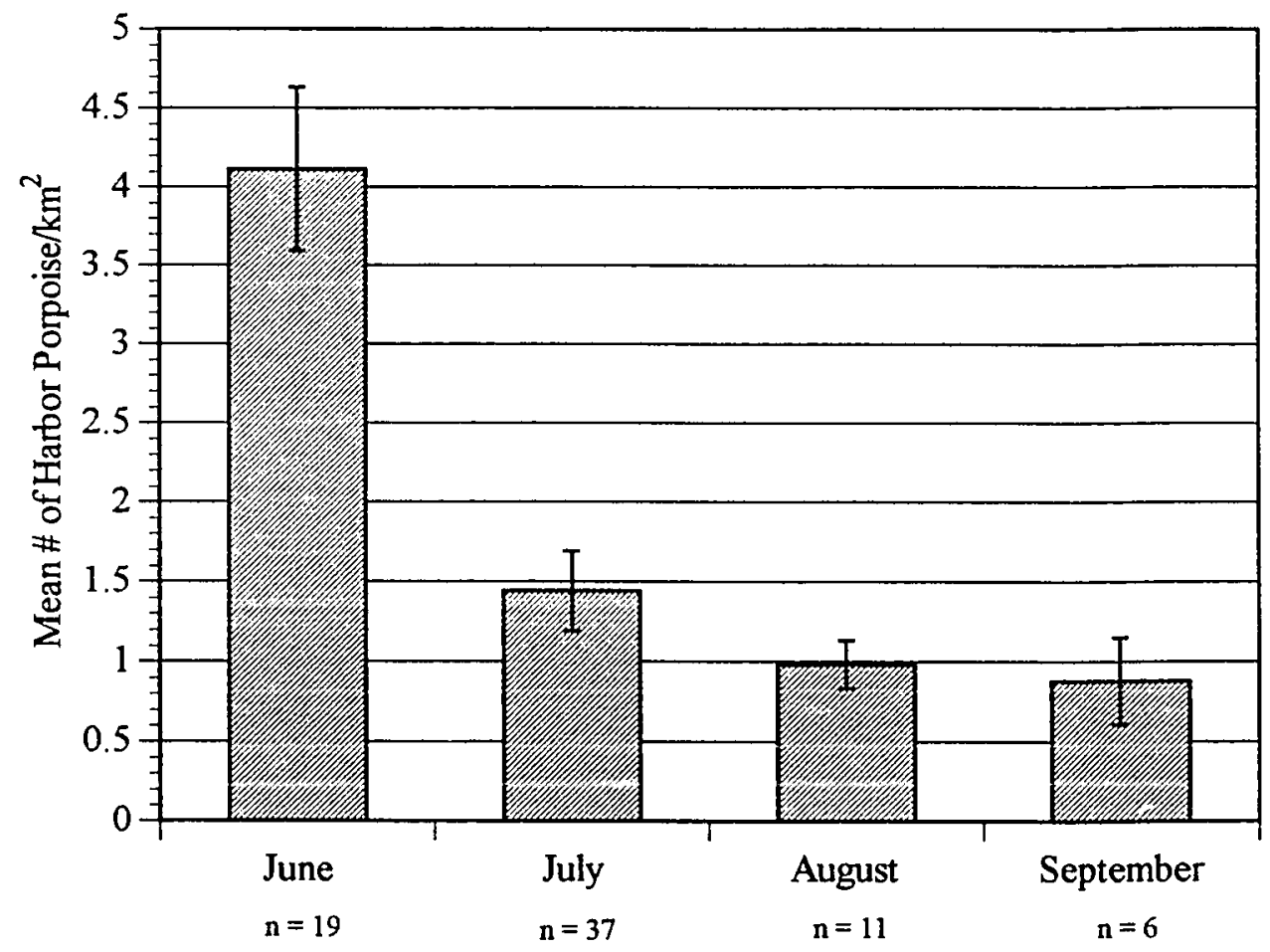

Figure 19. Density of harbor porpoise for four months of 1992 off Point Doughty, Orcas Island, Washington. Vertical lines represent standard error and " $n$ " represents the number of surveys in each month. 


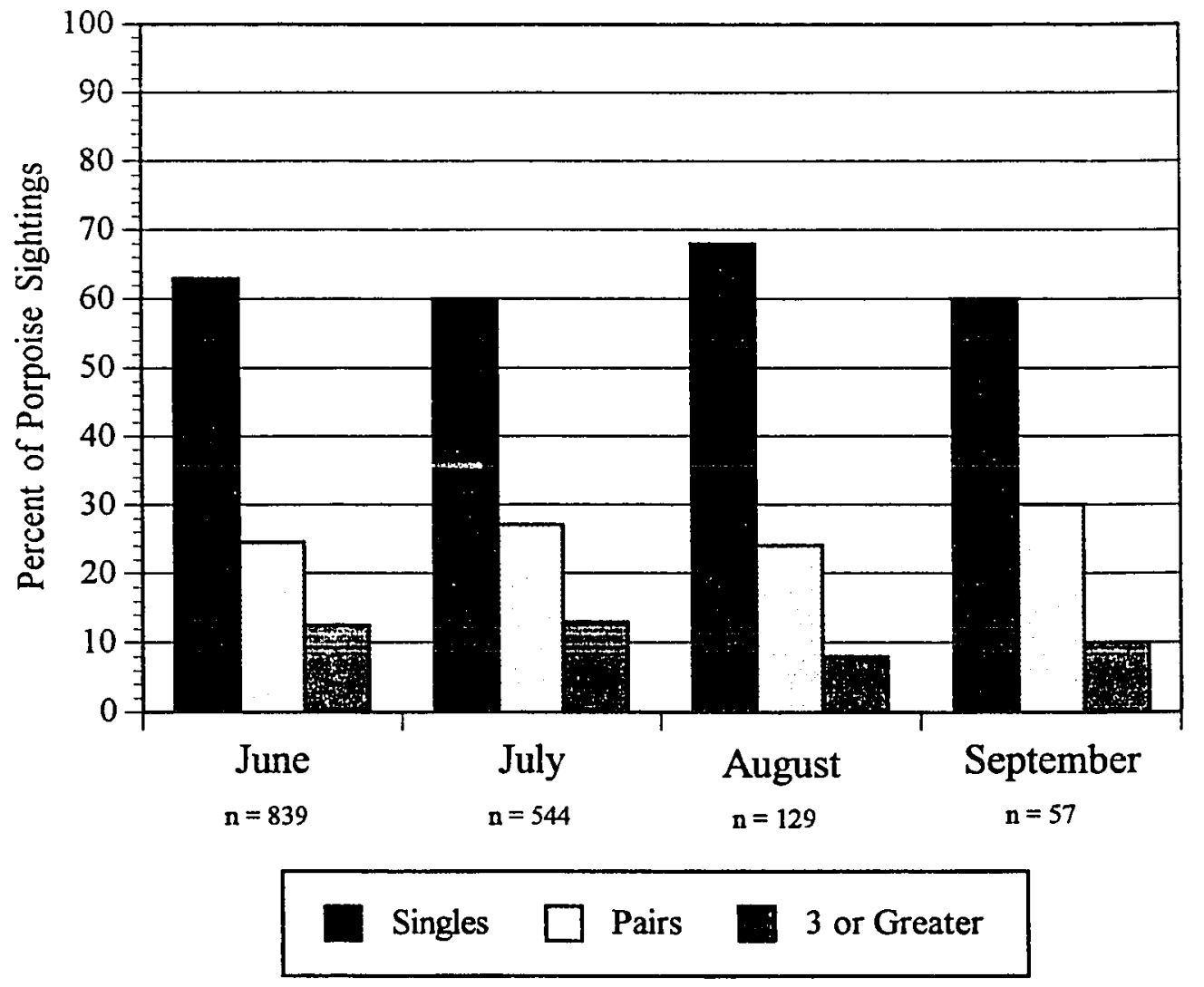

Figure 20. Group size of harbor porpoise in relation to month (determined during abundance surveys off Point Doughty, Orcas Island, Washington). "N" represents total number of harbor porpoise sightings within each month. 


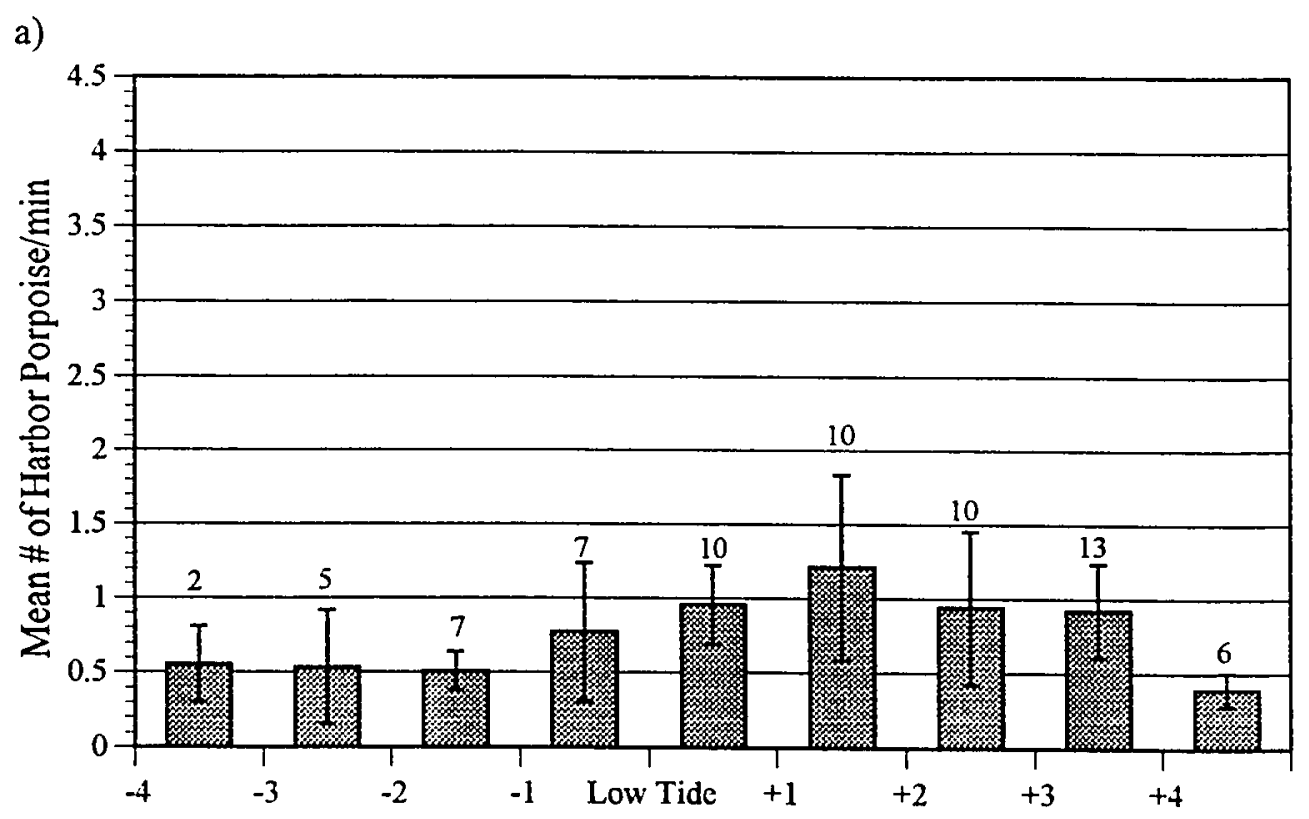

Hours Before and After Low Tide

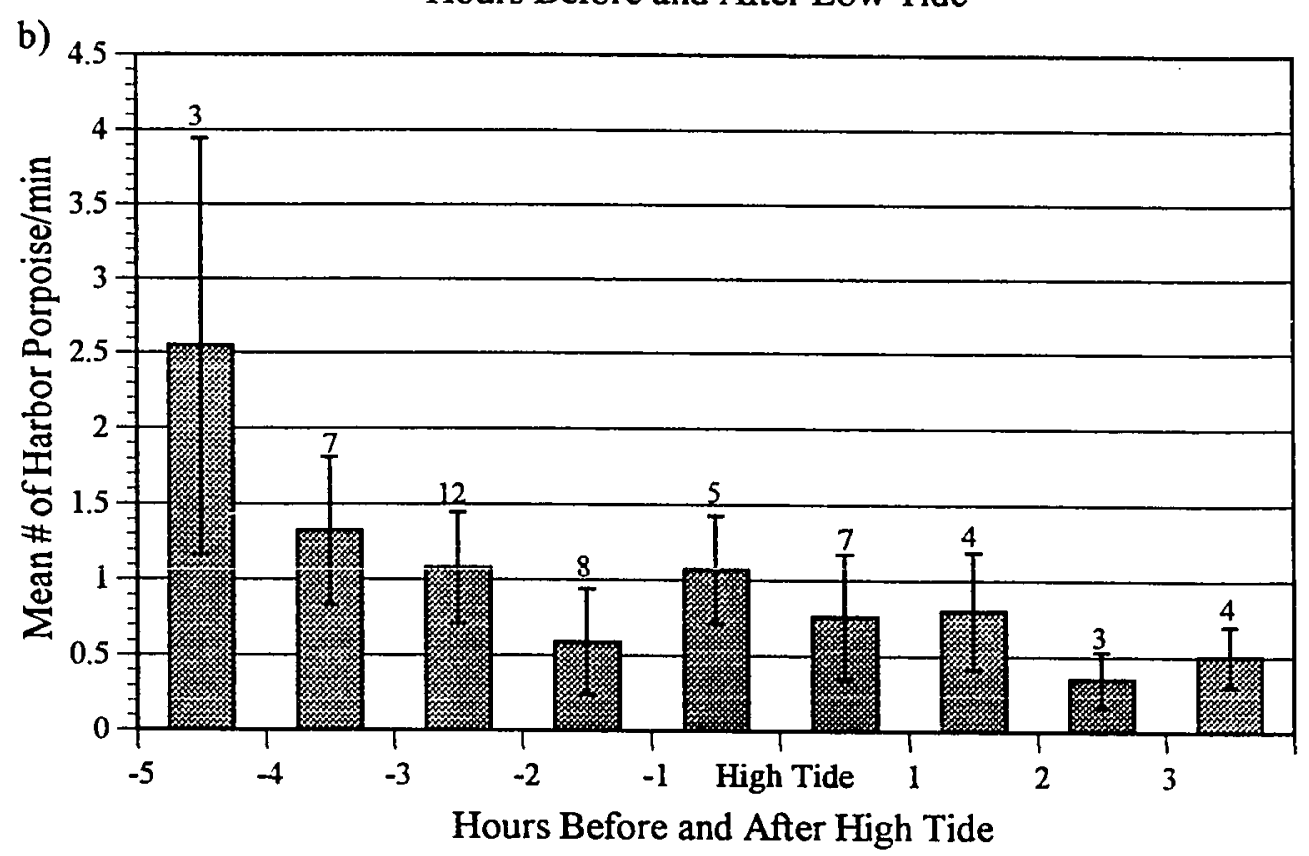

Figure 21. Mean number of harbor porpoise observed per minute before and after low tide (a) and high tide (b) offPoint Doughty, Orcas Island, Washington. The numbers above each bar represent sample size during each time block and vertical lines represent standard error. 


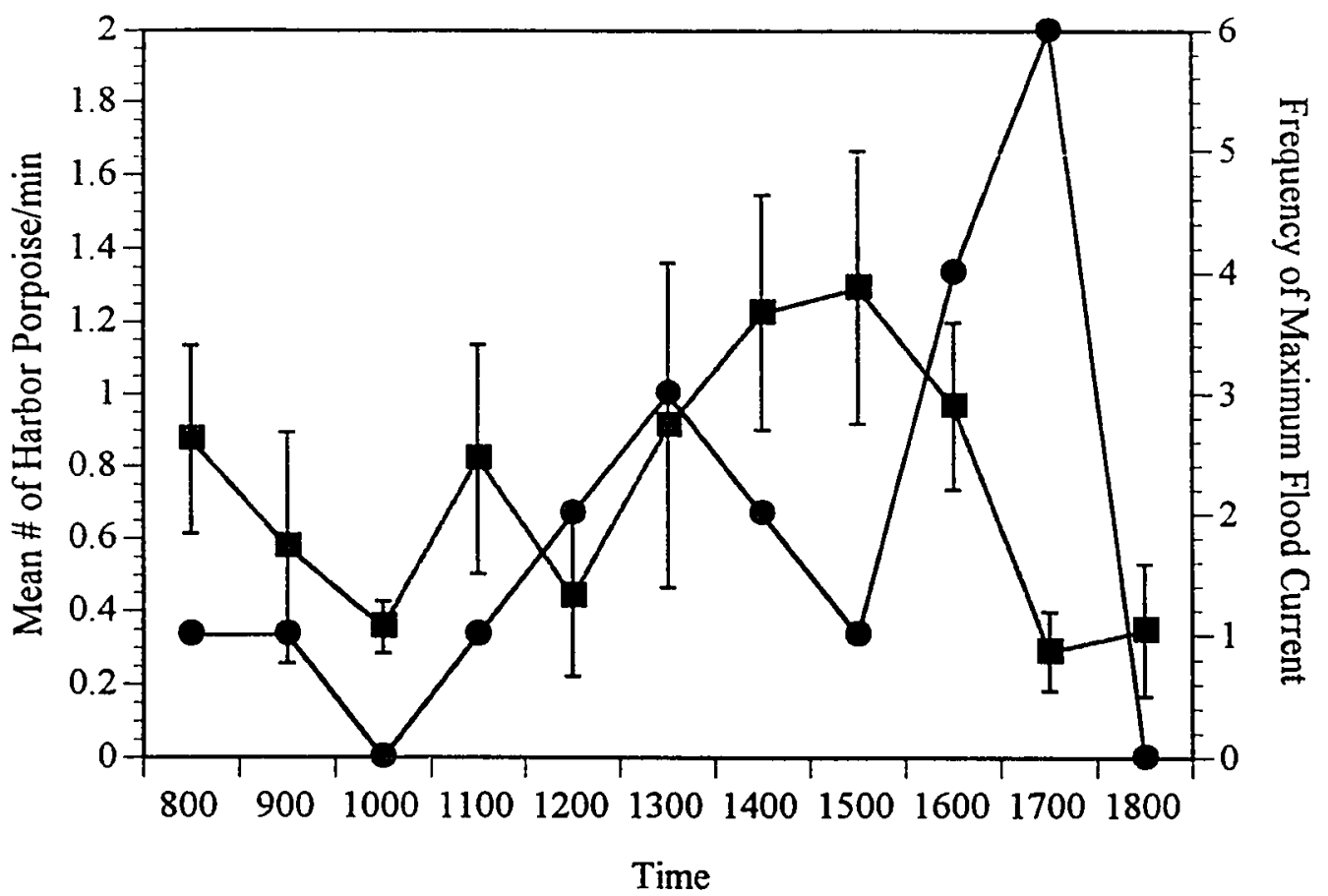

- mean \# of porpoise/min

- frequency of max flood current

Figure 22. Mean number of harbor porpoise observed per minute in relation to the frequency of maximum flood current recorded on twenty days (June to September 1992) during 69 abundance surveys off Point Doughty, Orcas Island, Washington. 


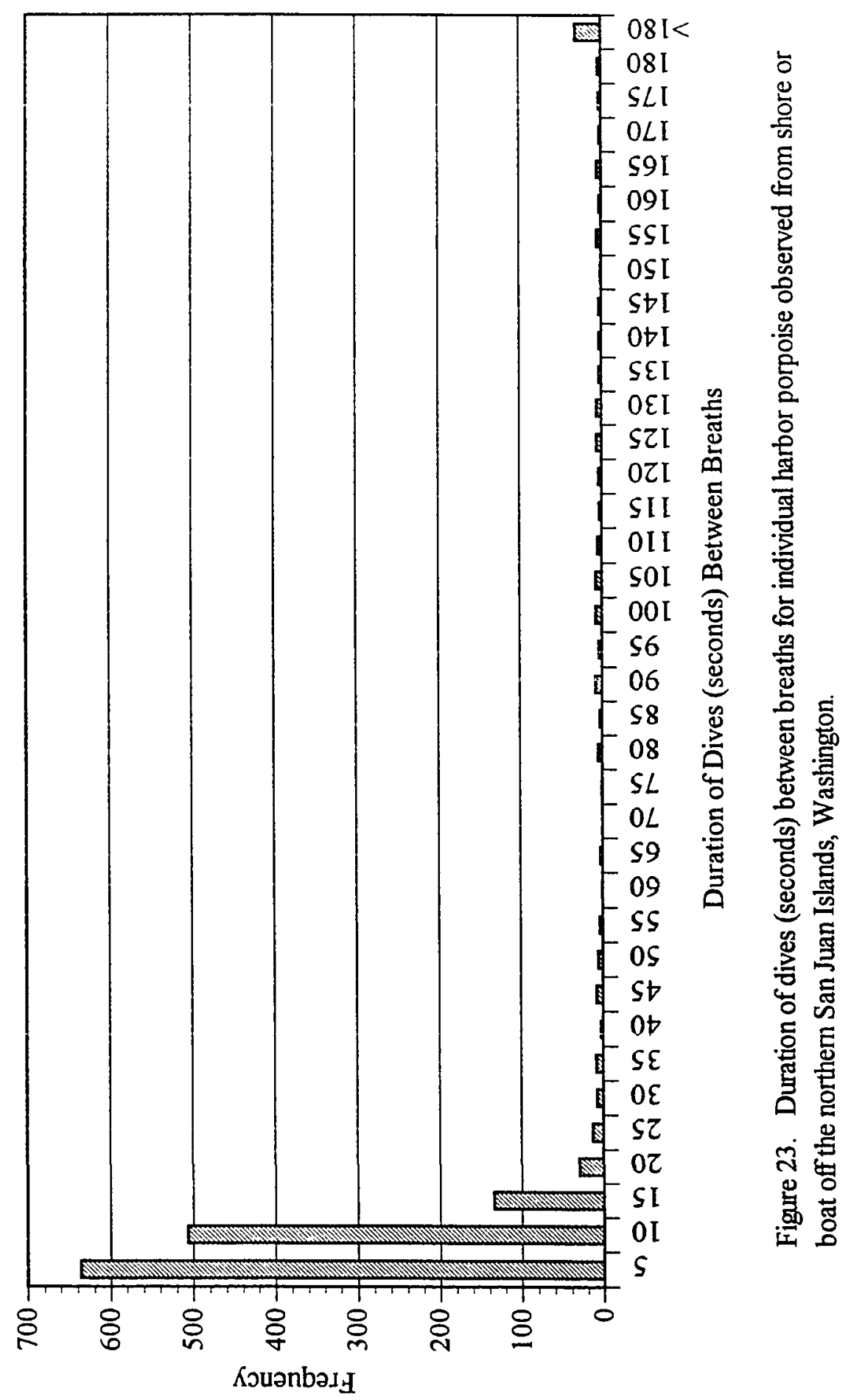




\title{
Appendix 1
}

\section{HARBOR PORPOISE VISIBLITY CODES}

\author{
$1=$ Excellent \\ Clear day or high clouds. No glare. Sea like \\ a mirror. No ripple. Maximum harbor porpoise \\ sighting distance $=2.0 \mathrm{~km}$. \\ $2=$ Very Good Clear or some cloud cover. No glare. Slight \\ surface ripple. Maximum harbor porpoise sighting \\ distance $=1.5$ to $2.0 \mathrm{~km}$. \\ $3=$ Good \\ Some glare, or boat so close to islands that \\ sea takes on a dark appearance from shadow \\ cast on the water. Slight surface ripple. \\ Maximum harbor porpoise sighting distance $=$ \\ 1.0 to $1.5 \mathrm{~km}$. \\ $4=$ Fair \\ Moderate glare. Glassy wave crests take on \\ a dark appearance - dark wavelets - difficult \\ to tell dorsal fin of porpoise from dark wavelets. \\ Light precipitation. Maximum harbor porpoise \\ sighting distance $=0.5$ to $1.0 \mathrm{~km}$. \\ $5=$ Poor \\ Glare is very bad. Light to moderate precipitation, \\ occasional to few whitecaps. Many dark wavelets. \\ Chop from tide rips. Maximum harbor porpoise \\ sighting distance $\leq 0.5 \mathrm{~km}$. \\ $6=$ Unacceptable \\ Full glare. Heavy precipitation. Surface chop, \\ scattered whitecaps. Maximum harbor porpoise \\ sighting distance $<0.5 \mathrm{~km}$.
}

